Univar Tonanto ligRegy 
"

, 
$=0$
$y=$

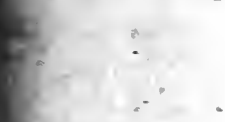



3

MARKETING PERISHABLE FARM PRODUCTS 
Digitized by the Internet Archive in 2007 with funding from Microsoft Corporation 
STUDIES IN HISTORY, ECONOMICS AND PUBLIC LA

EDITED BY THE FACULTY OF POLITICAL SCIENCE

OF COLUMBIA UNIVERSITY

Volume LXXII]

[Number 3

Whole Number 170

\title{
MARKETING PERISHABLE FARM PRODUCTS
}

\author{
BY \\ ARTHUR B. ADAMS, A. M. \\ Fellow in Economics, Columbia University \\ Assistant Professor of Economics at the University of Oklahoma
}

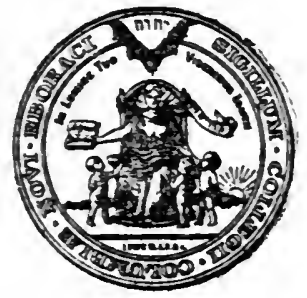

Wrew Dork

COLUMBIA UNIVERSITY

LONGMANS, GREEN \& CO., AGENTS

LONDON: P. S. KING \& SON, LTD.

1916 
Copyright, I9I6

BY

ARTHUR B. ADAMS 


\section{PREFACE}

THE work here offered is a study in the field of marketing agricultural products. Though I hope, in the near future, to expand this study so as to include the marketing of all farm products, this little volume is concerned only with the marketing of one class of these goods. The commodities selected are fruits, vegetables, dairy and poultry products which, for want of a better term, are called Perishables. From the marketing standpoint these products constitute a fairly homogeneous class, and the problems connected with marketing them are, in the main, very different from those connected with marketing Staples (wheat, corn, oats), or the Semi-staples (hay, live stock, tobacco, etc.).

The attempt is made to point out the fundamental economic forces which underlie the marketing of these goods and to suggest methods of controlling these forces so that the cost of passing the goods through the market processes may be reduced. It is hoped that the work may be of some value to men who are actually engaged in carrying on the trade, to public officials whose work is concerned with marketing, as well as to students who are interested in the problem.

In submitting the work it is realized that some of the conclusions as to remedies which should be applied are at variance with those of certain recent writers on the subject as well as with the position taken by some public officials. This is particularly true in regard to the advisability of encouraging a rapid and widespread development of direct marketing and of coöperative marketing. 
In the preparation of this work my thanks are due to Mr. Brand and other officials of the Office of Markets and Rural Organization for their kindness in furnishing the bulletins and pamphlets of that Office which touch on the subject. I am also indebted to many "middlemen" engaged in carrying on the trade, for the practical information which they have furnished on special problems. Mr. Urner of the Urner-Barry Co., publishers of the New York Producers' Price-Current, was very courteous in directing me to sources of information. Credit has been given in the foot-notes to various individuals and to government bodies that have suggested some of the ideas contained in the book.

I am under great indebtedness to the members of the Department of Economics of Columbia University and particularly to Professors Seligman and Mitchell. Both have offered valuable and constructive criticisms during the progress of the work. Professor Seligman made the publication of the study possible and Professor Mitchell kindly consented to read the proofs.

Columbia University, ApriL, igi6.

Arthur B. Adams. 


\title{
CONTENTS
}

\author{
CHAPTER I
}

PAGE

Character and Significance of the Problem

The Scope of the Investigation . . . . . . . . . . II

Extent of Trade in Perishable Produce. . . . . . . . . I3

Seasonal Fluctuations in Prices of Perishables . . . . . . . I6

Sectional Fluctuations in Prices of Perishables. ........ 18

Cost of getting Perishables from Producers to Consumers. . . . . 20

Losses from Decay of Perishables . . . . . . . . . . . 24

Summary of the Social Costs incident to the Marketing of this

Class of Goods. . . . . . . . . . . . . 26

Causes of the Demand for a Reduction in the Cost of Marketing these Products ................. 26

What Has Been Done to improve the Marketing of Perishables. . 30

Statistical Tables ............... 35

\section{CHAPTER II}

The Present System of Marketing Perishables

Outline of the Machinery of the Market . . . . . . . . 44 Complications and Lack of Uniformity in Marketing Operations . 48 Cost-factors of the Middleman System . . . . . . . . . 56 Distinction between the Middleman Machinery and its Operators. 72 Tables of Transportation Rates . . . . . . . . 74

\section{CHAPTER III}

\section{Why the System is a Burden to Society}

Reasons for Wide Fluctuations in Prices in Each Market. . . . . 76 The Fundamental Economic Forces which Regulate Prices. . . . 76 How these Forces Regulate the Prices of Perishables. . . . . 83 Sectional Margins in Prices: Causes. . . . . . . . . . . 89 Causes of Losses from Deterioration. . . . . . . . . . . 9I 
Causes for Wide Margins Between Farm Prices and Consumers' Prices ................... . 97

Summary of Factors to be Dealt With in Reducing the Social Costs of Marketing Perishables .......... ror

\section{CHAPTER IV}

Reform of the Marketing Processes or Machinery

Suggested Programs of Reform . . . . . . . . . . 103

Limitations of Direct Marketing ... . . . . . . . I05

Finding Consumers. ... . . . . . . . . r ro5

Transferring the goods to Consumers .......... II5

Economic Value of Marketing Machinery for Perishables. . . . . II6

Reduction of the Cost of Marketing through Simplification of the

Processes...................... II8

Sales by Producers ................ II8

Sales by Professional Shippers. . . . . . . . . . I23

Purchases by Retailers ... . . . . . . . . . . I25

Simplification of Marketing Processes through Coöperation and

Municipal Markets . . . . . . . . . . . I27

Farmers' Coöperative Marketing Associations. . . . . . . I27

Consumers' Coöperative Stores . . . . . . . . . . I28

Municipal Markets . . . . . . . . . . . . I29

Summary. . . . . . . . . . . . . . . I29

\section{CHAPTER V}

Reduction of Costs of Performing the Marketing Processes

Through Government Market Departments or Bureaus. . . . . . I3I

Standardization of Grades and Packages. . . . . . . . 132

Elimination of Unfair Business Practices. . . . . . . . . . I35

Organizing Market Information. . . . . . . . . . I38

Regulation of Transportation, Refrigeration and Terminal Facilities 143 Investigative and Educational Work. . . . . . . . . I45

Getting Efficient Market Departments. . . . . . . . . I48

Reduction of the Costs Through Coöperative Associations. . . . I50

Reduction of Costs through Competition. . . . . . . . I57

Among Shippers . . . . . . . . . . . . I57

In the Wholesale Trade. . . . . . . . . . . I58

In the Retail Trade. . . . . . . . . . . . . I59

\section{CHAPTER VI}

Reduction of the Burdens of Marketing by Changing the Nature of the Goods and Area of Production

Reduction of the Perishability of the Goods . . . . . . . . 164

Cold-storage .................. ${ }^{165}$ 
PAG

Manufacturing .......... . . . . . . . I68

Producing Hardier Varieties. . . . . . . . . . . . . 169

Reduction of Seasonal Production . . . . . . . . . . I70

Development of Varieties which have a Long Season of Harvesting I70

Widening the Area of Production for Different Goods . . . . . I7I

Development of Centralized Producing Sections . . . . . . I7 I

\section{APPENDIX}

A. The National Law for the Standardization of Apple Grades and Containers ... . . . . . . . . . . . . I75

B. Market Information of Peach Movement for One Day as given out by the Office of Markets of the U. S. Department of Agriculture ................... I77 



\section{CHAPTER I}

\section{Character and Significance of the Problem}

\section{SCOPE}

FroM the marketing standpoint, agricultural products may be divided into three classes, as follows: (1) The Staples; (2) The Semi-staples; and (3) The Perishable Food Products. There can be no question as to which commodities belong in the first class, as only those which are dealt in on the great produce exchanges are included. They are wheat, corn, oats, barley and cotton. These are called staples because they are comparatively non-perishable and have a continuous organized market. ${ }^{1}$ The second class comprises those products, other than the staples, which are used for further production either on the farm or in the factory, such as grains, seeds, hay, tobacco and wool; also, some food products which are not highly perishable, such as cattle, hogs and nuts. These commodities are sold in a more or less organized market though none of them are sold on the great produce exchanges. The third class includes, as its name indicates, all the perishable foods which are sold in practically unorganized markets-such as vegetables, fruits, dairy and poultry products. An attempt to enumerate the commodities which belong in each class has been made in Table I, p. 35. We are, however, concerned in this investigation with the perishables only.

1 Huebner, "Functions of Produce Exchanges," Annols of Amer. Acad. of Pol. and Soc. Sci., Sept. IgII, pp. I-35. 
Men who receive an income from buying and selling goods are ordinarily called "middlemen," and goods which pass through the hands of one or more middlemen in course of being marketed are said to be marketed through the " middleman system." " Our study will not only be confined to the marketing of those agricultural products which fall under the head of perishables but will be further limited to the marketing of those perishables which pass from producer to consumer through the middleman system. It will not be our aim either to defend or condemn this system: but to discover, if possible, the economic weaknesses connected with middleman methods and processes of marketing perishables and to suggest ways in which the system may be improved.

Neither is it to be inferred from the limitations which we set on our study that we mean to ignore entirely cooperative marketing and municipal markets. There are two reasons, other than time and space, for not considering either separately in our discussion: ( $\mathrm{r}$ ) to-day as much as 95 per cent of the perishables which enter into trade in the United States are marketed through the middleman system, ${ }^{2}$ and it is believed that for a long time to come the larger proportion of such produce will be so marketed; (2) it is also believed that both coöperation and municipal markets will better serve society by complementing the middleman system than by supplanting it. So, coöperation will be discussed in so far as it can be made to improve on the middleman system, and municipal markets and direct marketing will receive the same consideration.

Before discussing the technical problems connected with the present practices and methods of marketing perishables,

1 The Middleman System will be fully discussed in chap. ii.

2 Opinion of writer from general observation. 
we should get a clear conception of the bigness of the question as a whole and its importance to industrial society. Therefore, this chapter will treat of the development of commerce in perishables, present fluctuations in their prices, cost of marketing them, amount of product wasted by the system, reasons why improvements are now being so vigorously demanded, and what has been done to meet these demands.

\section{EXTENT OF TRADE IN PERISHABLE PRODUCE.}

So long as we were an individualistic agricultural nation there were few problems connected with the marketing of agricultural products, because there was little to be marketed except the surplus of a few staples and semi-staples such as cotton, wheat and cattle. Each farm was practically sufficient unto itself, producing most of what it consumed and consuming the larger part of what it produced. ${ }^{1}$ But our rapid development of manufacturing, transportation and trade has brought forth extensive commerce in all kinds of agricultural products. Our industrial development has so greatly affected the farming industry that it is, today, no longer an individualistic self-sufficing industry, but is, like mining and manufacturing, a highly commercialized one. ${ }^{2}$ The demand for farm produce on the part of towns and cities needing food and raw materials, together with the farmer's need for manufactured goods has caused him to produce largely for the market instead of producing for direct consumption. So the bigness and significance of the marketing of farm products has developed pari passi6 with our great change to an industrial nation and the resulting shifting of a large proportion of the population from the farms to the towns and cities.

I Coman, Industrial Hist. of U. S., pp. 214-216.

- Carver, U. S. Dept. of Agri., Yearbook I913, p. 239. 
This recent change of agriculture from an individualistic to a commercial industry had a much greater effect on the problems connected with marketing perishables than on those connected with marketing either of the other two classes of agricultural products. This has been due in a great measure to the rapid growth of trade in this class of commodities. Perishable food products have always made up a large percentage of the food consumed by the ordinary family. The Bureau of Labor Statistics estimates that about forty per cent of the money paid for food by the American workman goes to buy perishable farm produce. $^{1}$ So long as our population was largely rural there was of course little trade in this class of goods because each family produced about all it consumed. Even in 1880 when our urban population had grown so that 29.5 per cent was concentrated in towns and cities of 2,500 inhabitants or more, ${ }^{2}$ extensive commerce in farm perishables was comparatively unimportant. Then the towns and cities were small enough to produce their own perishables or to secure them from the nearby farms. But the rapid development of transportation facilities and the great growth of the cities since that time has changed the whole situation. To-day more than fifty per cent of our population is centered in towns and cities, ${ }^{3}$ many of which are so large that they are unable to get their perishable food from the immediate territory surrounding them, but are compelled to depend on farms hundreds of miles away. The following extract from the Report of the Mayor's Market Commission of New York City will give an idea of the source of the perishable food supply of a large American city ${ }^{4}$

1 Bureau of Labor Statistics, Bulletin No. 156, p. $3^{6} \mathrm{r}$.

- United States Census I9I0, vol. v, p. I7.

'Ibid., p. I7.

'Report of Mayor's Market Commission of New York City, p. II. 
To-day the development of railroad and steamship has brought the farms of South Carolina and Kansas as near New York City as were those of Long Island and Westchester County one hundred years ago. It has removed any limitations on the growth of the city imposed by the difficulty of getting an adequate food supply, and as a consequence, the city has grown until it is dependent upon the production of a very wide area for its continued existence.

The commonest articles of food are often brought great distances; potatoes, for instance, are brought to the New York market from Maine, from the Western States, from Bermuda, Scotland, Ireland, and Belgium; onions, from the SouthVirginia, South Carolina and Texas, from the Western States. and from Italy and Spain; green vegetables of all kinds are brought from nearby farms and in very large quantities from the South and West-in the flush seasons one railroad bringing over three hundred cars a day, and one steamship line running two steamers daily in the busy season between New York and Virginia ... apples come from New England and New York, the Middle West, Oregon and Washington ... melons from California, Colorado and the South ... and so on.

The source of New York's dairy and poultry supply would show even a greater area of origin than the fruits and vegetables above mentioned. It is estimated that at the present time the average haul to the City of New York of the food stuffs it eats would require four days of fast freight. ${ }^{1}$

As the time and space between the producer and consumer of perishable foods became greater, it was, of course, impossible for them to deal directly with each other, so some kind of machinery for handling the rapidly growing trade had to be devised. As the task was too great for either producer or consumer and as all other classes of foods had heretofore been handled through the middleman system, it was only natural that the same system should be applied

${ }_{1}$ Report of Mayor's Market Commission of New York City, p. 252. 
largely to the marketing of perishables. Consequently there are to-day great armies of country shippers, commission men, wholesale men, jobbers and other middlemen engaged in handling perishables. ${ }^{1}$ And the machinery and methods of performing the task have become the most complicated, and probably the most inefficient, of all marketing machinery in the world.

\section{SEASONAL FLUCTUATIONS IN PRICES OF PERISHABLES}

It is considered almost an axiom that the prices of agricultural commodities fluctuate more violently than do those of manufactured goods. The annual fluctuations in the price of wheat, the most stable of all agricultural commodities, have, since 1902, been very much greater than those of pig iron, the basic commodity upon which manufacturing depends. ${ }^{2}$ The great variations in the prices of agricultural produce as compared with the fluctuations in prices of manufactured goods and natural-resource products becomes more striking when short period changes (daily or weekly fluctuations) are noted. It is not uncommon for cotton to change ten per cent in price within a day or so, or even within a few hours, whereas the rise or fall in prices of manufactured or natural-resource goods occur, as a rule, very gradually and over a long period of time. ${ }^{3}$

There is a marked difference between the fluctuations in prices of the three classes of agricultural commodities. The prices of the staples are much more uniform than those of the other two classes, whereas, the variations in prices of perishables are far more violent than with other agricultural products. ${ }^{4}$ While the price of cotton may change ten

${ }^{1}$ Report of Mayor's Market Commission of New York City, p. II.

2 Statistical Atlas 1913, pp. 495-496.

${ }^{3}$ Mitchell, W. C., Lectures on Business Cycles.

* Wholesale prices are here referred to. 
per cent in a few hours the price of almost any fruit or vegetable may, in the same time, fall eighty per cent or rise 400 per cent. ${ }^{1}$ By comparing the weekly quotations of the staples, as given in any newspaper, with the weekly quotations of the perishables given in Tables II and III, ${ }^{2}$ one will readily see the extreme irregularity in the prices of the latter as opposed to the former. The fluctuations in the prices of the semi-staples will range between those of the Staples and the Perishables. ${ }^{3}$

It will be noticed from the tables referred to above that, on the whole, poultry products fluctuate less violently than do any other class of perishables, and that eggs are the most variable commodity of this class. In order of percentage of fluctuation poultry products are followed by dairy products. Cheese varies less than do either butter or milk. Fruit follows dairy products in order of variation of price, and, as will be noticed, is far more variable than dairy products. Among the fruits, peaches and cantaloupes are the most changeable. The second week of July, I9I4, peaches sold in the New York wholesale market from fifty cents to four dollars per bushel, and cantaloupes the same week sold from fifteen cents to three dollars and fifty cents per crate. But of all perishables, fresh vegetables are the most unsteady in price; though on an average, the range of daily or weekly prices is no greater than for peaches or cantaloupes. Tomatoes and cabbage are more violent in their fluctuations than other vegetables.

The retail prices of all products vary less than the wholesale prices. ${ }^{4}$ In the case of a product which fluctuates violently in wholesale price, as most perishables do, the retail

1 Table no. ii, p. 36.

2 Pp. 36-37.

3 Prices of semi-staples given in Yearbooks of Dept. of Agri.

4 Mitchell, W. C., Lectures on Business Cycles. 
price is fixed at a point which will give the retailer a profit even when he buys his goods at the highest wholesale price. So the great fluctuations in the wholesale prices of perishables injures the producer greatly, because he often has to sell his produce far below cost of production; ${ }^{1}$ and the consumer is benefited very little, as the price he has to pay remains comparatively high." Therefore, the great variations in the prices of perishables cause the producer to receive less for the product, and the consumer to. pay more than where a steady price is maintained. In short, fluctuations add greatly to the cost of the system.

\section{SECTIONAL FLUCTUATIONS IN PRICES OF PERISHABLES}

Table No. IV ${ }^{3}$ shows the estimated farm price of selected commodities in different states at the same time. It will be noticed that on July I, I9I4 the price of wheat varied from sixty cents in Oklahoma to one dollar and twenty-three cents in Georgia. But the farm prices in the great wheat-producing states of the West varied little, having a range of from sixty cents to eighty-six cents, with an average of about seventy-five cents. The variation in hay was much greater, selling on September I, I9I4 at five dollars per ton in North Dakota and at twenty-two dollars and fifty cents in Connecticut, with a price of about six dollars in the great hayproducing states. The extreme variations in the prices of butter and eggs are shown to be no greater than those of wheat. June I5, I9I4 the farmers were selling eggs in Missouri at fourteen cents while Massachusetts farmers were getting twenty-eight cents, and Arizona farmers thirtyone cents. September I, I9I4 butter was bringing thirty-

${ }^{1}$ United States Department of Agriculture, Report No. 106, pp. 43-58.

- See Discussion of Retail Price-Making, chap. iii.

3 P. 39. 
six cents in Massachusetts and only eighteen cents in Tennessee, but with a general high range in the East and a low range in the West. When we turn to cabbage and tomatoes we find greater discrepancies in farm prices than in any of the commodities already considered. On October 15, 1914 the Arkansas farmers who had cabbage to sell were, on the average, able to get three dollars per hundred pounds, while the farmers of New York were selling them at forty-five cents per hundred pounds. Without exception the price of cabbages on this date was low in the states where they were being harvested and high where there were few for the market. The price range for tomatoes was about as great as that for cabbage. It will be noticed from the table that perishables as a class vary in price from place to place much more than do the other classes of farm produce.

A full discussion of the reasons for the great sectional variations in prices of perishables will be given in Chapter III ; it is sufficient to say here that they are due either to the impossibility, or the exceptionally high cost, of getting the produce from the places where it is lowest in price to the place where it is highest. In other words, the more easily and cheaply a farm commodity can be made to flow to the point of greatest demand, the more uniform will be the price received by the farmers throughout the country. It is clear that under our present system of marketing perishables they do not flow very readily from place to place-at least not at a reasonable cost.

This great discrepancy in sectional prices of perishables is very expensive to both producers and consumers. The farmer in one place will not be able to sell his surplus produce at cost of production, while the consumer in another will have to pay very high prices for the same produce because there is a scarcity of the article in his section. 
I. COST OF GETTING PERISHABLES FROM PRODUCER TO CONSUMER

From the business standpoint "cost of marketing" is the cost in terms of dollars and cents of getting a commodity from the producer into the possession of the one who consumes it. It is from this viewpoint that the cost of marketing is here discussed. In the case of manufactured consumers' goods the producer is the manufacturer and the consumer is the household; in the case of agricultural products the producer is the farmer and the consumer is either the factory or the household. Where an agricultural product goes through a process of manufacture before it is ready for human consumption, as cotton is made into cloth, the factory is regarded as the consumer, but where one is consumed by the household without changing its form, as most fruits and vegetables are, the household is the consumer. The greater proportion of Staples and Semi-staples are consumed by factories, whereas, most perishables pass from producer to household without going through a process of manufacture.

An examination of cost of marketing is a difficult task. ${ }^{1}$ It is seldom possible to ascertain the exact cost of marketing even a standardized manufactured commodity, as has been proved by the investigations of the Tariff Commission into the cost of marketing cotton and woolen cloths, ${ }^{2}$ and by Harvard University in its studies of marketing shoes. ${ }^{3}$ It is far more difficult to ascertain the cost' of marketing agricultural products than that of marketing manufactured goods. This is true, because of the great seasonal and sectional variations in prices of farm commodities, and

1 Martin, Prof., Amer. Econ. Rev., vol. v, p. 145.

${ }^{2}$ Reports of Tariff Commission on Woolen and on Cotton Schedule.

3 Bulletins of the Bureau of Business Research, Harvard University. 
because of the additional fact, which we shall discuss in Chapter II, that there is little uniformity of method in marketing them. Consequently the figures of cost of marketing which are given below are to be taken only as estimates. It is not to be understood, however, that no importance is to be attached to them, for it is believed that they very closely represent the average cost in each case and that they give a true picture of the relative cost of marketing each class of commodities discussed.

The average cost of marketing farm produce is much greater relatively than that of marketing manufactured goods. In the latter class the cost varies greatly between different classes, being lowest with the standardized, trustcontrolled goods such as kerosene oil and Arrow Collars, and highest with the novelties which are subject to change in style like women's hats and men's cravats. Considering the whole field of manufactured goods the cost of marketing ranges from to to 70 per cent of the consumer's price with an average of from 30 to 40 per cent. ${ }^{1}$ Whereas, the average cost of marketing agricultural products as a class is from 40 to 50 per cent of what the consumer pays for them, with a very much wider range of cost for different commodities and classes of commodities than with manufactured goods. ${ }^{2}$ The average for the three great classes of farm products is about as follows: Staple Products 20 to 25 per cent of consumers' price: Semi-staples 35 to 40 per cent; and Perishable Foods 60 to 65 per cent. ${ }^{3}$

It will be noticed that it costs a great deal more to market the perishables than to market either of the other two classes of agricultural products. The exceptionally high cost for

${ }^{1}$ Martin, Prof., Amer. Econ. Rev., vol. v, p. 145.

2 Weld, Univ. of Minn. Bul. No. 4, Soc. Sci. Studies, p. 7.

3 Table v, p. 40, and table vi, pp. 4I-42. 
many commodities in the perishable class stands out clearly when we divide them into sub-classes. The cost for dairy produce is from 45 to 50 per cent; for poultry produce 50 to 55 per cent; while that for fruits and vegetables is from 65 to 75 per cent. ${ }^{1}$ A close examination of Table VI, which gives the average cost of marketing certain selected perishables, will show that there is little uniformity in the cost for the different products, but that the lowest cost is much higher than for most Semi-staples or any Staples.

There has been a considerable increase in the cost of marketing most classes of "consumers' goods" in recent years. $^{2}$ The margin between wholesale and retail prices has gradually grown wider. From 1900 to 1913 wholesale prices of foods increased 27 per cent, while retail prices increased 58.6 per cent. ${ }^{3} \quad$ There are no reliable index numbers for perishable foods as a class either for farm, wholesale, or retail prices, but the data which we have available indicate that the cost of marketing them has increased more rapidly than the cost for any other class of consumers' goods. According to Dun's figures wholesale prices of dairy and garden products rose 59 per cent between 1900 and I91 3,4 and as poultry and fruit products belong to the same class it is probable that, in the same period, the wholesale prices of perishables as a class rose between 55 and 60 per cent. It is certain that the retail prices of perishables more than kept pace with the wholesale prices. But the farm prices, as given in the Farmers' Bulletins of the United States Department of Agriculture, indicate that the farmer received very little more for them in I9I3 than in

${ }_{1}$ Table v, p. 40, and table vi, pp. 4I-42.

${ }^{2}$ Mitchell, W. C., Lectures on Business Cycles.

${ }^{3}$ Bureau of Labor Statistics, Bul. No. 173, p. 75, and Bul. No. 156, p. 382 .

4 Ibid., pp. $15 \mathrm{I}-52$. 
1900. The farm prices of dairy and poultry products have risen 35 to 40 per cent since 1900 , while the prices of fruits and vegetables have risen much less, so it is probable that the average farm prices for perishables now is not more than 30 per cent higher than the farm price in 1900. Therefore, since this time, the cost of marketing this class of products has greatly increased.

The marketing of all classes of goods in European countries seems to be less expensive than in America. The investigations of the Tariff Commission show very conclusively that the cost of marketing cotton and woolen goods is very much less there than here. ${ }^{1}$ That American-madegoods sell more cheaply in the shops of London and Paris than in those of New York and Chicago is due, not so much to the American Tariff, as to the difference between the cost of marketing here and abroad.

Agricultural products as a class are marketed far more cheaply in Europe than in America. ${ }^{2}$ This is particularly true of perishables. The European farmers reeeive a higher average price, ${ }^{3}$ and the consumer pays less for this class of goods than in America." On the average, the retail price of potatoes in the European cities, as shown in Table VII, ${ }^{5}$ is about one-half of what it is here. The price of butter and milk is from one-half to two-thirds of that in America, and chickens and eggs are also cheaper. There is little doubt that the price of vegetables and fruits in the

${ }^{1}$ Reports of the Tariff Commission on Woolen and Cotton Schedules.

2 Plunkett, Sir Horace, Senate Doc. No. 214, 63 Cong., Ist ses., p. 839.

3 Testimony before the American Commission on Coopperative Marketing in Europe, Senate Doc. No. 214, 63d Cong., I ses.

'Price of Food Products in Europe, June, 1914, in the various tables given in Bul. I7O of the Bureau of Labor Statistics compared with American prices. These were prices which prevailed in Europe prior to the outbreak of the war.

- Infra, p. 43. 
European cities is one-half what it is here, though there are no statistics on this point. Meat and flour are higher than in America, but this is not due to the high cost of marketing but to the fact that these goods are produced at a much higher cost there than here, and that a great part of the supply is imported from abroad. ${ }^{1}$

\section{LOSSES FROM DECAY OF PERISHABLES}

The greatest social losses which occur in connection with marketing perishables lie, neither in the wide fluctuation or sectional variation in the prices of the same commodities nor in the actual expense of getting those goods from producers to consumers - though, as we have seen, these factors make the marketing system very burdensome. The greatest burden of all lies in the fact that a very large proportion of the perishables which are produced for market never reach consumers at all, but are completely lost by being allowed to decay. Part of this decay occurs on the farms (before the goods have a chance to enter the market) and the other part occurs after the goods are turned over to the marketing agencies. ${ }^{2}$

An exceptionally large percentage of the fruits and vegetables raised for market, decay on the farmers' hands before a market can be found for them. The proportion of dairy and poultry products which perish on the farms is smaller than for fruits and vegetables, but still it is considerable. It

${ }^{1}$ Report of the Secretary of Agriculture 1914, p. 8.

${ }^{2}$ The value of the losses from decay which occur after the goods have entered the hands of the middlemen is included in the statistics of the "Cost of Getting Perishables from Producers to Consumers" given in the preceding section. A discussion of these losses is given in this section so that the "expense of running the marketing system" and the losses from decay may be distinguished. The "cost of marketing" includes both factors. 
is estimated that between 20 and 30 per cent of perishables as a class decay on the farms before they can be sold. ${ }^{1}$

At least 25 per cent of the perishables which arrive at the wholesale markets is hauled to the dump-pile because it is unfit for human consumption. ${ }^{2}$ In the year I9I I the New York Board of Health condemned and destroyed 6,500,000 pounds of fruit and 2,500,000 pounds of vegetables because of decay. ${ }^{3}$ In warm weather Florida oranges lose 30 per cent in transportation alone, ${ }^{4}$ and if we add the decay after the fruit reaches the consuming center the total loss would be astounding. There is a loss of I7 per cent in eggs from producer to consumer, due to breakage, decay, etc., ${ }^{5}$ but butter has an equally great loss. The greater proportion of the perishables which are consumed in the cities are much inferior, because of partial deterioration, to what they were when they left the farms. It is not an over-estimate, therefore, to say that between 30 and 40 per cent of the perishables which are raised on the farms are never consumed at all, but are a complete social loss.

That this decay of perishables works a great hardship upon both producers and consumers is too evident to require much discussion. It often happens that farmers in one section are unable to sell their peaches, tomatoes or other perishables because they decay before a market is found for them while at the same time consumers in some cities are unable to buy the same produce at a reasonable price because the available supply in their market is very

1U. S. Dept. of Agri., Report 98, pp. 166-284, and Report ro6, pp. 43-59.

2 Estimation made up from conversation with wholesale men in several cities.

3 Pennington, Report of Mayor's Market Commission of New York. City, p. 252.

- Bureau of Plant Industry, Circular No. I9, p. I.

' Farmers' Bulletin No. 517, p. 13. 
small. ${ }^{1}$ So the farmers lose part of their crops, while consumers are unable to get as much of the same crops as they would like and must pay high prices for what they do get. It is the business of a market to bring supply and demand together, and something is radically wrong if it fails to accomplish this.

\section{SUMMARY OF THE WHOLE PROBLEM}

We may summarize the whole problem as follows: Farmers produce far more perishables than they are able to market. Those which they succeed in marketing fluctuate so violently in price from day to day that the growers cannot approximate one day what they will receive for their goods the next. The average price which the farmer receives for his goods is very low as compared with what the consumer pays for the same class of goods. Consumers are paying higher prices for perishables than the consumers of Europe pay for them, and the supply which they are able to get is very irregular. Between the producer and the consumer we find a great deterioration or decay of goods, and an expensive method of gatting the goods from one to the other.

VIII. CAUSES OF THE DEMAND FOR A REDUCTION IN THE COST OF MARKETING PERISHABLES

Even though the waste and inefficiency in the system of marketing perishables has been great enough to attract public attention, it is due to underlying economic changes in our industrial society that great interest has been aroused in the problem. Probably the most important of these changes is the diminishing power of wage-earners and farmers to buy the necessities of life. From I896 to I907 wages in the

${ }^{1}$ Brooks, J. T., Markets and Rural Economics, pp. 189-190. 
United States rose 27 per cent, ${ }^{1}$ but food and clothing in the same period rose in wholesale price 40 per cent, ${ }^{2}$ and in retail price about 50 per cent. ${ }^{3}$ Again from 1907 to 1913 wages rose ir.6 per cent, ${ }^{4}$ while wholesale prices of food increased 17 per cent, ${ }^{5}$ and retail prices 20 per cent. The position of the day-laborer is therefore becoming more undesirable and he has begun to demand a change. His fight for a further increase of his wages has not been successful enough to satisfy him, so he now demands cheaper living.

On the other hand, the farmer's purchasing power has also shown appreciable signs of diminishing in recent years. As long as there was plenty of cheap fertile land he was able to increase his income so easily by increasing his production that he was not vitally interested in the price he received per unit. But the days of cheap land are now gone. In 1900 to 1910 the value of farm land in the United States as a whole more than doubled per acre. ${ }^{6}$ This was a gain to those who owned the land during the rise in value, but it is an added burden to non-land owning farmers and to those who have recently purchased land. The problem now is to increase returns on a limited number of acres and this cannot be done by increase of production beyond a certain point. It is a well-known economic principle that after a certain limit of intensive cultivation is reached the returns from the land do not increase in proportion to the labor and capital expended upon it. It is certain that in

1 Mitchell, Business Cycles, p. 133.

Bureau of Labor Statistics, Bul. 173, p. 126.

s Supra, p. 22.

2 Statistical Abstract 1913, pp. 249-25I.

- Bureau of Labor Statistics, Bul. 173, p. I26.

- U. S. Census I910, vol. v, p. 27. 
some sections of the country we have already reached the point of diminishing returns for labor on our land. As we approach this stage the tiller of the soil, in order to maintain his standard of real income, must receive more for the products he raises or buy his necessities at a lower price. But prices of farmer's necessities are not falling but continually rising, and rising faster than the prices he receives for his products; so his purchasing power has been decreasing for the past few years. According to the estimates of Mr. Nat C. Murrah, Assistant Chief of the Bureau of Crop Estimates, the farmer's purchasing power decreased five per cent between 1909 and I9I $4 .{ }^{1}$ So the farmer is beginning to demand a better price for his products, and particularly for his perishables.

Another economic change in our industrial life which has brought the perishable food problem to the forefront is our increasing dependence on this class of commodities as a source of food supply. Indications are that we as a nation must depend less and less upon beef and pork as our main diet and more and more upon vegetables, fruits and domestic fowls. The per capita number of animals raised on our farms has greatly decreased since 1900 . In that year the number of cattle per capita for the country was .89 while in 1914 it was only .57 ; the figures for swine are .83 for 1900 and .60 for I9I4; and for sheep, .8I in 1900 and .50 in $1914 .^{2}$ Not only has the per capita number of these animals decreased greatly but in each case the actual number for the period has decreased. This is not the place to enter upon a detailed discussion of the causes for the decrease, it is sufficient to say that it has been largely due to the rapid rise in the price of land. Cattle- hog-and sheep-raising is a

${ }^{1}$ Farmers' Bulletin No. 645, p. 18.

'Farmers' Bulletin No. 575, p. 8. 
frontier industry and as the country is more thickly settled it is driven out by more intensive crops. ${ }^{1}$ The important fact for us to note here is that if we, as a nation, are to have a cheap food supply in the future it must come largely from the plant kingdom rather than from the animal. More human food can be raised on a given area of land by the production of plant than of animal crops.

As has already been shown, forty per cent of the money paid for food by the ordinary workman goes to buy perishables. This percentage is a great deal higher to-day than it was ten years ago because the price of meat has risen so rapidly in the past few years. As the cost of producing meat will, in the future, continue to rise higher and higher the workman will consume less meat and more perishables. Daylaborers will not be the only ones affected; all except the very rich will feel the strain. Our people, then, will depend more and more upon perishables for their food supply. This is why consumers, as a class, are becoming so intensely interested in the marketing of these goods.

Because of the rapid rise in the price of land, and the increased demand for perishables on the part of the cities and towns, the dependence of farmers upon them as a money crop is growing very rapidly. According to the census estimates of I9IO, given in Table I, ${ }^{2}$ perishables constituted twenty-three per cent of the total value of the output of the agricultural industry, and, as explained in the table, were greatly under-estimated so that their value is probably twenty-five to thirty per cent of the total. As agriculture becomes more intensive and the urban population grows to greater proportions the farmer will depend

${ }^{2}$ Carver, Principles of Rural Economics, pp. 157-162.

2 P. 35. 
more and more upon perishables as his money-crop. So he has become greatly interested in the marketing of perishables.

When we take into consideration the social losses connected with the system of marketing perishables, the rapidly decreasing purchasing power of laborers and farmers, together with the increasing dependence of both rural and urban population on these commodities, we not only see why the problem has become one of general interest, but we can also appreciate its far-reaching importance to the nation as a whole. When the country was new and population scarce in proportion to the natural resources, the marginal production of labor in the factory and on the farm was so high, and the possibility of increasing this production so great, that attention was naturally centered on increasing the output. A greater national income could be secured by producing a larger quantity than by utilizing what was produced to the best social advantage. Waste was not extravagance because more could be gotten by spending energy to augment the output than by spending it in conserving and utilizing the smaller production more advantageously. But the situation has changed and waste is now becoming a burden and a great burden in regard to perishable foods. It is now difficult for the farmer to increase output except at an increasing expense per unit of produce, the laborer can rarely succeed in augmenting his wage except at a great increase of effort, so both are demanding the elimination of waste connected with the exchange between them in order to increase their real incomes.

IX. WHAT HAS BEEN DONE TO IMPROVE THE MARKETING OF PERISHABLES

Farmers have made many efforts through coöperative associations to reform the methods of marketing perishables. There have been a few such associations which have made 
signal successes, ${ }^{1}$ but the greater number so far organized have been pronounced failures. They have neither advanced the personal welfare of the coöperators nor improved marketing. It is a generally conceded fact that such organizations have, up to this time, had little appreciable effect on the general problem. ${ }^{2}$

There has also been much talk recently of consumers' cooperation in this country, but as yet the supporters of the plan have largely confined themselves to pointing out the great successes coöperative stores have made in Europe, particularly in England. The Right Relationship League has organized I5O such stores in the United States since $1903,{ }^{3}$ but the success of these stores has not been so very encouraging. It might be said that as yet consumers' cooperation in this country is only a hope-not an accomplished fact. The effect which such coöperation has had on the general problems of marketing perishables is far less than that accomplished by farmers' coöperative organizations.

There are about two dozen American cities which claim to have municipal markets of some character, but there is not one where a very large proportion of the perishables consumed by the city goes through the municipal markets. However, great improvements have been made in many of these American municipal markets in the past few years and there is little doubt that at least in some of the cities they have enabled a portion of the population to secure cheaper

${ }^{1}$ Description of Farmers' Coöperation in U. S.; U. S. Dept. of Agri., Report No. 98, pp. 166-284.

2 Tousley, E. M., Annals of Amer. Acad. of Pol. and Soc. Sci., vol. L, p. 230.

${ }^{3}$ Ibid., pp. 231-233.

4 Public Markets in American Cities, Report of Mayor's Market Commission of New York City, p. 67. 
food. But up to this time it cannot be said that even these public markets have had an appreciable influence on the general system of marketing perishables.

There are evidences that the middlemen themselves have become interested in improving their methods of handling perishables. ${ }^{1}$ Their associations have studied some of the problems and have passed resolutions calling for certain reforms. They have, however, accomplished less than nothing in the way of evident improvements and the system has constantly grown worse in their hands.

Yet, in the face of the general failure on all sides to reform the system, it is not believed that the problem is a hopeless one. The greater part of the past discussion of the question and not a few of the moves made to improve conditions have been only the hysterical efforts of people unacquainted with the true economic complications and unable to grapple with this big economic problem which has appeared on the horizon. So far, little scientific investigation or discussion has been devoted to the marketing of perishables. There are, however, indications that many economists and trained experts will, in the future, give their time to the problem.

Wisconsin, New York and a few other states have established commissions or bureaus to study the marketing of farm produce. These state commissions are too new for us to tell as yet just what they will be able to accomplish in the way of bringing about constructive reforms, but the work now being done by the New York State Department of Foods and Markets and by the Wisconsin University Extension Department is indeed encouraging. A few cities have appointed market and food commissions to study the local problems, and the Report of the Mayor's Market Commission of New York City is a valuable one.

${ }^{1}$ Weld, Univ. of Minn., Bul. in Soc. Sci. No. 4, p. Io. 
As the result of a conference held under the auspices of the Department of Agriculture at Washington in April 191 $3{ }^{1}$ Congress created in this Department the Office of Markets, which, a year later, was combined with the Office of Rural Organization. It is the object of the Office of Markets and Rural Organization to collect and distribute useful information on "subjects relating to the marketing and distribution of farm products." Though the office of markets is yet young, connected with it is a corps of experts in marketing who have already made invaluable studies in special phases of the problem. ${ }^{2}$ If Congress sees fit further to increase the appropriations of this office it will in time become the chief clearing house for scientific information on all questions connected with marketing agricultural products, particularly perishables, for as shown by the Reports of the Chief of the Office the larger part of its work is concerned with marketing this class of produce.

The economic societies of the country have lately shown not a little interest in the marketing of perishables. In 1913 a whole meeting of the American Acadeny of Political and Social Science was taken up in discussing problems connected with "Reducing the Cost of Food Distribution," 3 and since that time many separate articles on this problem have appeared in the annals of this organization. The American Economic Association has not neglected the question, for a whole session of its annual meeting in I9 4 was taken up with the problems of marketing. ${ }^{4}$ Aside from these two large scientific organizations many of the smaller ones have devoted much of their space and time to problems

${ }^{1}$ Report of Conference issued by Dept. of Agri.

3 The various reports will be mentioned in later chapters.

- Annals for November, 1913.

- American Econ. Rev., Papers and Proceedings of 1914 meeting. . 
34 MARKETING PERISHABLE FARM PRODUCTS [396 of marketing perishables. Also many individual economists have very recently turned their attention to questions of marketing agricultural products. ${ }^{1}$ So it is likely that the problem will receive sufficient scientific study within a short time to justify a constructive program for reorganizing the system of marketing perishables. It is hoped that the discussion of the problem which is found in the following pages will contribute something to that scientific basis for the reform.

'Weld of Yale, Taylor of Wisconsin, Coulter of Peabody, Carver of Harvard. 


\section{TABLE I}

The Three Groups of Farm Products-Value of Each ${ }^{1}$

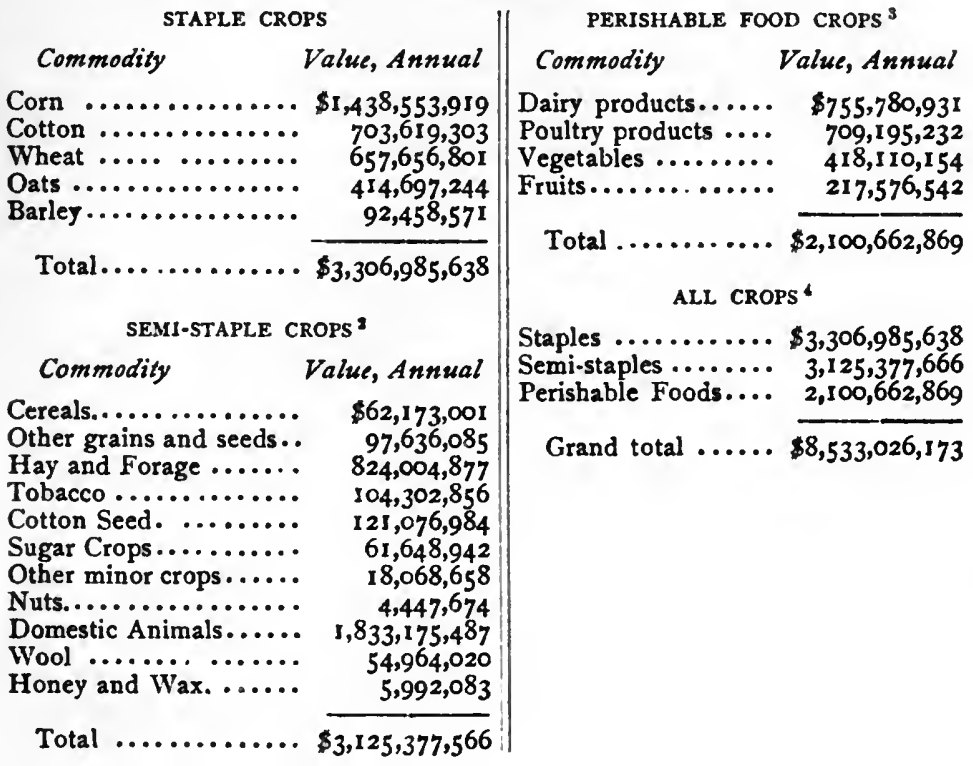

${ }^{1}$ Census of 1910 : Vol. V. pp. 474, 505, 517, 519, 532.

'There is much duplication in the estimated values of the Semi-Staple Crops because much of one product is used in producing another. For example, hay and forage are used in producing live-stock but the full value of each is here given. Then too, a great part of the Staple Crops, such as corn and oats, is consumed in the production of live-stock.

'The perishable foods are very probably greatly underestimated because such a large percentage of the crops is consumed or wasted on the farm and the farmers have no way of estimating the true value.

"The grand total is probably near the value of the annual production of the agricultural industry because the over-estimates and under-estimates tend to equalize each other. 


\section{TABLE II}

\section{Fluctuation in the Prices of Fruits and Vegetables}

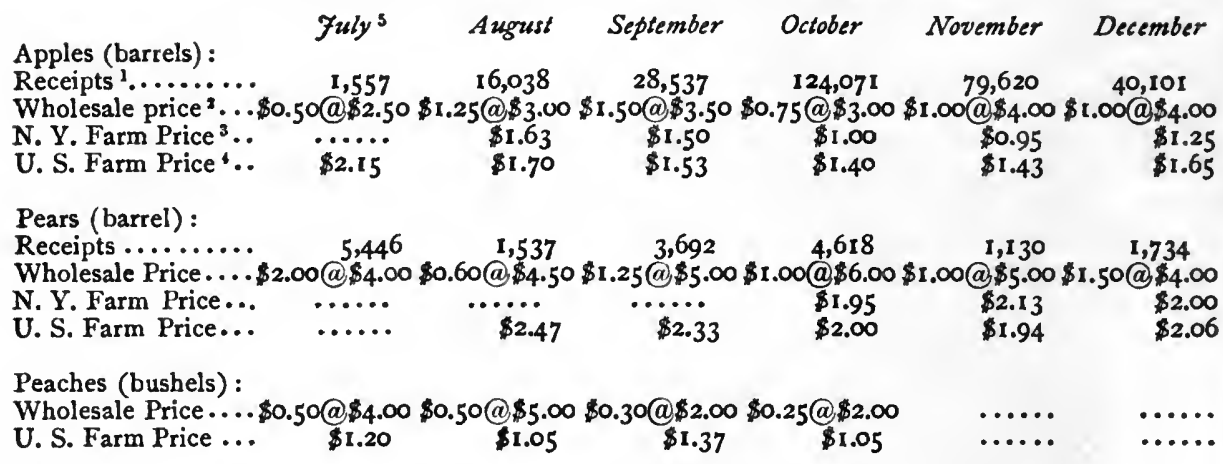

Cantaloups (crate)

Wholesale Price....\$0.15@\$3.50\$0.12@\$1.75\$0.25@\$2.00\$0.60@\$1.50

Cabbage ( 100 pounds)

Wholesale Price....\$0.50@\$2.00\$0.25@\$3.00\$2.00@\$3.00\$2.50@\$3.50\$1.50@\$2.00\$2.50@\$3.50 U. S. Farm Price... \$2.66 \$1.74 \$1.50 \$1.31 \$1.14 \$1.25

Tomatoes (box)

Wholesale Price....\$0.20@\$2.50\$0.10@\$0.35\$0.15@\$1.00\$0.50@\$1.00\$0.50@\$1.50\$0.40@\$1.00

Celery (doz. bunches)

Wholesale Price....\$0.10@\$0.50\$0.10@\$0.25\$0.10@\$0.40\$0.10@\$0.35\$0.10@\$0.25\$0.10@\$0.50

Lettuce (basket)

Wholesale Price....\$o.1o@\$0.75\$0.10@\$0.30\$0.25@\$1.25\$0.15@\$0.75\$0.25@\$1.00\$0.25@\$1.50

Spinach (basket)

Wholesale Price.... $\quad . . . . \quad$..... \$0.25@\$5.00\$0.30@\$0.50\$0.25@\$0.35\$0.15@\$0.20

Green Peas (bushel)

Wholesale Price....\$0.50@\$1.25\$0.40@\$1.50\$0.50@\$1.75\$1.50@\$2.50\$0.75@\$1.75

1 For the City of New York for the second week in each month. Receipts were estimated from the current issues of The Producers' Price-Current of N. Y., and are to be taken only as estimates.

'Wholesale prices of New York City according to quotations given by The Producers' Price-Current

${ }^{3}$ The average price which the New York farmer receives for the commodity on the $15^{\text {th }}$ of the month referred to. These prices were secured from Farmers' Bulletins Nos. 611, 620, 629, 641, 645, 651. They also are to be considered as estimates.

'The average price which the farmers of the United States receive for the commodity on the $15^{\text {th }}$ of the month designated. The figures were taken from the Farmers' Bulletins referred to in note 3 .

- The prices quoted are only those of the second week of each month. 
TABLE III

Monthly Receipts and Wholesale Prices of Dairy and Poultry Products IN NEW YORK CITY FOR 1914

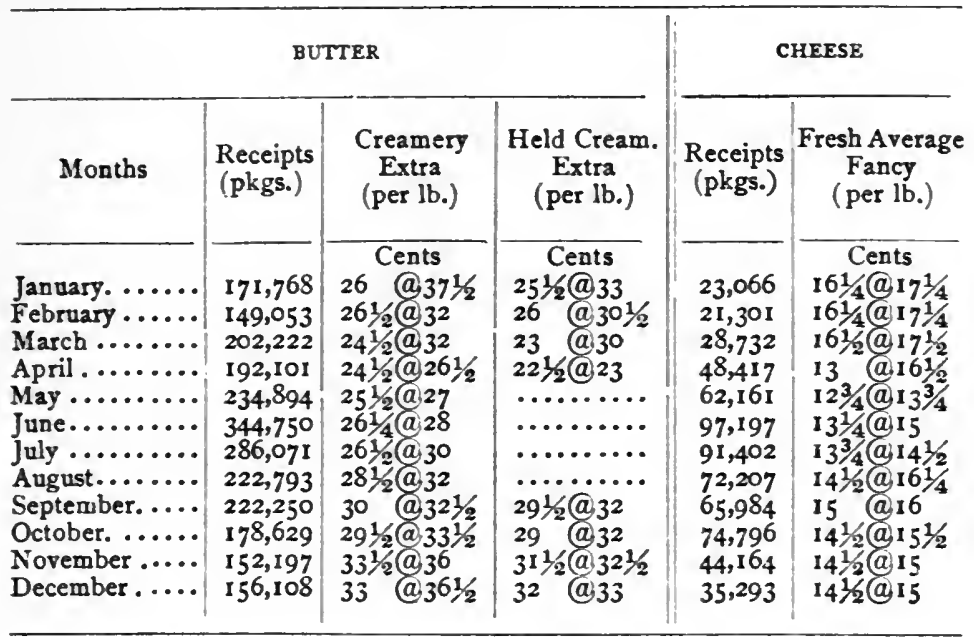

\begin{tabular}{|c|c|c|c|c|c|}
\hline \multicolumn{4}{|c|}{ DRESSED POULTRY } & \multicolumn{2}{|c|}{ LIVE POULTRY } \\
\hline Months & $\begin{array}{l}\text { Receipts } \\
\text { (pkgs.) }\end{array}$ & $\begin{array}{c}\text { Fresh Killed } \\
\text { Fowls } \\
\text { (per lb.) }\end{array}$ & $\begin{array}{c}\text { Frozen } \\
\text { Fowls } \\
\text { (per lb.) }\end{array}$ & $\begin{array}{c}\text { Receipts } \\
\text { (car } \\
\text { loads) }\end{array}$ & $\begin{array}{c}\text { Fowls } \\
\text { (per lb.) }\end{array}$ \\
\hline 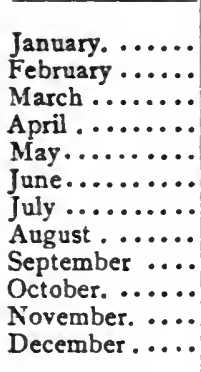 & \begin{tabular}{|r|}
132,908 \\
75,119 \\
100,941 \\
87,537 \\
74,362 \\
71,294 \\
52,257 \\
46,430 \\
60,249 \\
66,867 \\
98,713 \\
188,169
\end{tabular} & \begin{tabular}{l}
\multicolumn{3}{c}{ Cents } \\
$12 @$ a. 19 \\
14 a. 19 \\
14 a.19 \\
15 a. $191 / 2$ \\
$131 / 2 @ 191 / 2$ \\
$131 / 2$. $181 / 2$ \\
$121 / 2 @ 191 / 2$ \\
$121 / 2 @ 191 / 2$ \\
$13 @ 20$ \\
$13 @$ a. 20 \\
$111 / 2 @ 181 / 2$ \\
$12 @ 171 / 2$
\end{tabular} & 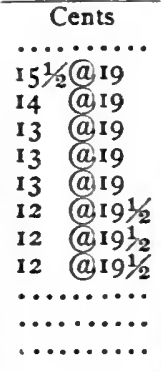 & $\begin{array}{l}477 \\
382 \\
443 \\
517 \\
424 \\
460 \\
492 \\
504 \\
736 \\
686 \\
670 \\
748\end{array}$ & $\begin{array}{c}\text { Cents } \\
\text { 141/2@16 } \\
\text { 161/2@20 } \\
\text { 151/2@.23 } \\
161 / 2 @ 23 \\
15 @ 19 \\
143 / 4 @ 191 / 2 \\
161 / 4 @ 19 \\
15 @ 181 / 2 \\
16 @ 19 \\
12 @ 20 \\
111 / 2 @ 16 \\
111 / 2 @ 161 / 2\end{array}$ \\
\hline
\end{tabular}


TABLE III-CONCLUDED

\begin{tabular}{|c|c|c|c|}
\hline \multicolumn{4}{|c|}{ EGGS } \\
\hline Months & $\begin{array}{l}\text { Receipts } \\
\text { (cases) }\end{array}$ & $\begin{array}{l}\text { Western Finest } \\
\text { (per doz.) }\end{array}$ & $\begin{array}{l}\text { Refrigerator } \\
\text { First to Finest } \\
\text { (per doz.) }\end{array}$ \\
\hline 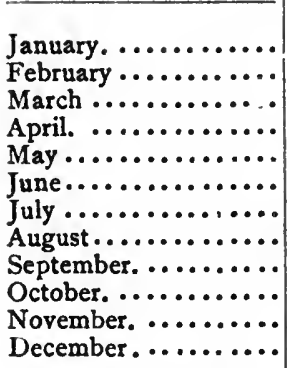 & $\begin{array}{l}188,287 \\
269,552 \\
466,452 \\
555,953 \\
778,391 \\
587,840 \\
386,845 \\
365,261 \\
349,731 \\
277,881 \\
176,366 \\
\times 59,517\end{array}$ & 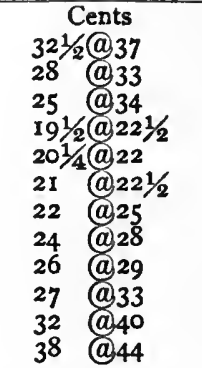 & \begin{tabular}{l}
\multicolumn{1}{c}{ Cents } \\
$291 / 2 @ 321 / 2$ \\
$25 @ 30$ \\
$271 / 2 @ 28$ \\
$\ldots . . . . .$. \\
$\ldots \ldots \ldots . .$. \\
$\cdots \ldots \ldots . .$. \\
$231 / 2 @ 251 / 2$ \\
$25 @ 27$ \\
$231 / 2 @ 27$ \\
$211 / 2 @ 251 / 2$ \\
$231 / 2 @ 26$ \\
$231 / 2 @ 27$
\end{tabular} \\
\hline
\end{tabular}

From prices and receipts quoted by The Producer's Price-Current of New York. 


\section{TABLE IV}

Discrfpancies between the Prices of the same Commodity in different States on the Same Date in 1914.

\begin{tabular}{|c|c|c|c|c|c|c|}
\hline & $\begin{array}{l}\text { Wheat } \\
\text { (per bu.) } \\
\text { July } 1\end{array}$ & $\begin{array}{c}\text { Hay } \\
\text { (per ton) } \\
\text { Sept. I }\end{array}$ & $\begin{array}{c}\text { Eggs } \\
\text { (per doz.) } \\
\text { June } 15\end{array}$ & $\begin{array}{c}\text { Butter } \\
\text { (per lb.) } \\
\text { Sept. I }\end{array}$ & $\begin{array}{c}\text { Cabbage } \\
\text { (pet } 100 \text { lb.) } \\
\text { Oct. } 15\end{array}$ & $\begin{array}{l}\text { Tomatoes } \\
\text { (per bu.) } \\
\text { Oct. 15 }\end{array}$ \\
\hline Maine. .......... & $\ldots \ldots \ldots$ & $\$ 13.70$ & $\$ 0.24$ & $\$ 0.31$ & $\$ 1 . \infty 0$ & $\$ 0.90$ \\
\hline New Hampshire... & $\$ 1.05$ & 18.60 & .24 & .33 & 1.30 & .85 \\
\hline Vermont ......... & 1.00 & 15.90 & .20 & .31 & .................. & 1.00 \\
\hline Rhode Island ..... & ......... & 21.00 & .27 & .35 & .75 & .80 \\
\hline Massachusetts ..... & $\ldots \ldots \ldots$ & 19.00 & .28 & .36 & .90 & 1.00 \\
\hline Connecticut........ & $\ldots \ldots \ldots$ & $21.5^{\circ}$ & .25 & .34 & 1.50 & .65 \\
\hline New York ......... & \begin{tabular}{|l|}
.98 \\
\end{tabular} & 14.90 & .22 & $.3 I$ & .45 & $.5 i$ \\
\hline New Jersey........ & I.OI & 19.20 & .26 & .33 & .75 & .40 \\
\hline Pennsylvania...... & .92 & 14.40 & .22 & .30 & 1.40 & .67 \\
\hline Delaware ......... & .85 & 15.00 & $.2 \mathrm{I}$ & ........ & 1.50 & .29 \\
\hline Maryland.......... & .85 & 15.30 & .19 & .26 & 1.25 & .47 \\
\hline Virginia. ......... & .95 & 17.10 & .18 & .23 & 1.90 & .60 \\
\hline West Virginia. .... & 1.00 & 17.60 & .19 & .25 & 1.60 & .65 \\
\hline North Carolina .... & 1.05 & 18.00 & .18 & .24 & 1.70 & .90 \\
\hline Soutb Carolina .... & 1.14 & 18.00 & .20 & .25 & 2.00 & 1.10 \\
\hline Georgia .......... & 1.23 & $17 \cdot 3^{\circ}$ & .18 & .24 & 2.00 & 1.25 \\
\hline Florida ........... & $\ldots \ldots$ & $18.7^{\circ}$ & .21 & .33 & 3.10 & 1.18 \\
\hline Ohio............. & .85 & 14.50 & .18 & .27 & 1.40 & .50 \\
\hline Indiana ........... & .76 & $14.7^{\circ}$ & .17 & .24 & 1.40 & .50 \\
\hline Illinois ........... & .72 & 14.80 & .16 & .27 & 1.60 & .68 \\
\hline Michigan. ........ & .86 & 12.20 & .19 & .26 & 1.20 & .50 \\
\hline Wisconsin ........ & .85 & 9.40 & .17 & .29 & 1.25 & .80 \\
\hline Minnesota. ........ & .78 & 6.30 & .16 & .27 & 1.95 & 1.00 \\
\hline Iowa ............ & .77 & 10.30 & .16 & .26 & 1.95 & .75 \\
\hline Missonri ......... & .71 & 14.10 & .14 & .23 & 1.80 & .75 \\
\hline North Dakota. .... & .78 & 5.00 & .15 & .23 & 2.75 & 1.50 \\
\hline South Dakota. .... & .77 & 5.80 & .15 & .20 & 2.35 & 1.05 \\
\hline Nebraska......... & .70 & 7.10 & .15 & .23 & 1.80 & .95 \\
\hline Kansas............. & .70 & 8.40 & .15 & .24 & 1.50 & 1.10 \\
\hline Kentucky ......... & .78 & $17.4^{\circ}$ & .15 & .21 & 2.00 & .55 \\
\hline Tennessee ......... & .85 & 18.60 & .15 & .18 & 2.00 & .50 \\
\hline Alabama ......... & 1.12 & 14.80 & .16 & .23 & $2.3^{\circ}$ & .80 \\
\hline Mississippi........ & ........ & 12.70 & .16 & .22 & 2.70 & $1 . \infty$ \\
\hline Louisiana ........ & $\ldots \ldots$ & $12.5^{\circ}$ & .18 & .29 & 2.50 & ......... \\
\hline Texas. ............ & .77 & 9.80 & .15 & .23 & 2.60 & 1.40 \\
\hline Oklahoma ......... & .60 & 8.90 & .14 & .23 & 2.25 & 1.30 \\
\hline Arkansas .......... & .86 & I 2.90 & .16 & .23 & 3.00 & .70 \\
\hline Montana .......... & .75 & 7.80 & .22 & .30 & 1.55 & $1 . \infty 0$ \\
\hline Wyoming ........ & .90 & 9.20 & .23 & .27 & 2.25 & 1.50 \\
\hline Colorado .......... & .77 & 8.40 & .21 & .28 & .60 & .95 \\
\hline New Mexico...... & 1.10 & 10.30 & .24 & .34 & 1.90 & 1.30 \\
\hline Arizona ........... & 1.20 & 12.60 & $.3 \mathbf{i}$ & .34 & 2.50 & $2.05-$ \\
\hline Utah ................. & .80 & 8.00 & .20 & .30 & 2.20 & .80 \\
\hline Nevada........ & .90 & 10.30 & .30 & .36 & 2.50 & 1.65 \\
\hline Idaho. ............ & .72 & $6.5^{\circ}$ & .19 & .27 & 1.80 & $1.80^{\circ}$ \\
\hline Washington ...... & .73 & 9.70 & .22 & $.3 \mathrm{I}$ & 1.50 & 1.00 \\
\hline Oregon ........... & .77 & 9.00 & .23 & .33 & 2.00 & 1.00 \\
\hline California ......... & .94 & 7.20 & .24 & .29 & 1.40 & .60 \\
\hline
\end{tabular}

These figures were taken from the price quotations in Farmers' Bulletins Nos. 6II, 620, 641. They are Farm Prices. 


\section{TABLE V}

\section{Cost of Marketing Agricultural Staples}

\begin{tabular}{|c|c|c|}
\hline Commodity & From farmer to factory & $\begin{array}{l}\text { From farmer to individual } \\
\text { consumers }\end{array}$ \\
\hline 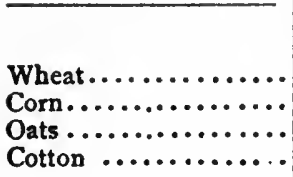 & $\begin{array}{c}\text { Per cent of factory price } \\
10^{1} \\
12^{2} \\
12^{3} \\
9^{4}\end{array}$ & $\begin{array}{l}\text { Per cent of individual con- } \\
\text { sumers' price } \\
20^{1} \\
30^{2} \\
30^{3}\end{array}$ \\
\hline
\end{tabular}

\section{Cost of Marketing Semi-staples}

\begin{tabular}{|c|c|c|}
\hline Commodity & From farmer to factory & $\begin{array}{l}\text { From farmer to individual } \\
\text { consumers }\end{array}$ \\
\hline $\begin{array}{l}\text { Cattle, hogs and sheep } \\
\text { Horses, mules and asses } \\
\text { Tobacco } \ldots . . . \ldots \ldots \\
\text { Hay and forage } \ldots \ldots \\
\text { Grains and cereals...... }\end{array}$ & $\begin{array}{c}\text { Per cent of factory price } \\
4 \text { to } 6^{5} \\
\ldots \ldots 10^{7} \\
6 \text { to } 10^{7} \\
\ldots \cdots \text { to } 12^{8}\end{array}$ & $\begin{array}{c}\text { Per cent of individual con- } \\
\text { sumers' price } \\
30 \text { to } 35^{6} \\
35 \text { to } 40^{6} \\
\ldots . \ldots \ldots \ldots \\
40 \text { to } 50^{8} \\
35 \text { to } 40^{8}\end{array}$ \\
\hline
\end{tabular}

Cost of Marketing Perishable Foods

Commodity

From farmer to the individual consumers.

Poultry Produce................

Dairy Produce

Per cent of individual consumers' price

Fruits .......................

Vegetables.

50 to $55^{9}$
$45^{10}$ to $50^{10}$
70 to $75^{11}$
70 to $80^{12}$

1 Bureau of Lab. Statistics, Bul. No. 130, pp. 70-102.

${ }^{2}$ The cost of marketing corn to the manufacturer is a little higher than for wheat because of its lower specific value and greater shrinkage. Cost to consumer is gotten by comparing farm prices in the West with farm prices in the South and East on the same date as given in Farmers' Bulletin No. 611, p. 27.

The cost of marketing oats is gotten the same way as for corn.

- Spot price in N. Y. compared with Southern farm price on same date.

6 Warren-Univ. of Minn. Studies., Bul. No. 4. p. 35.

- Selling price in horse-raising states vs. prices in other states. U. S. Census I9ro, Vol. v, p. 368.

Bureau of Plant Industry, Bul. 268.

Gotten by same methods as in footnote ( $\left.{ }^{2}\right)$.
Table VI, p. 41 .
${ }^{10}$ lbid.
11 Table VI, p. 42.
1s Jbid., p. 42. 
TABLE VI

Cost of Marketing Perishables

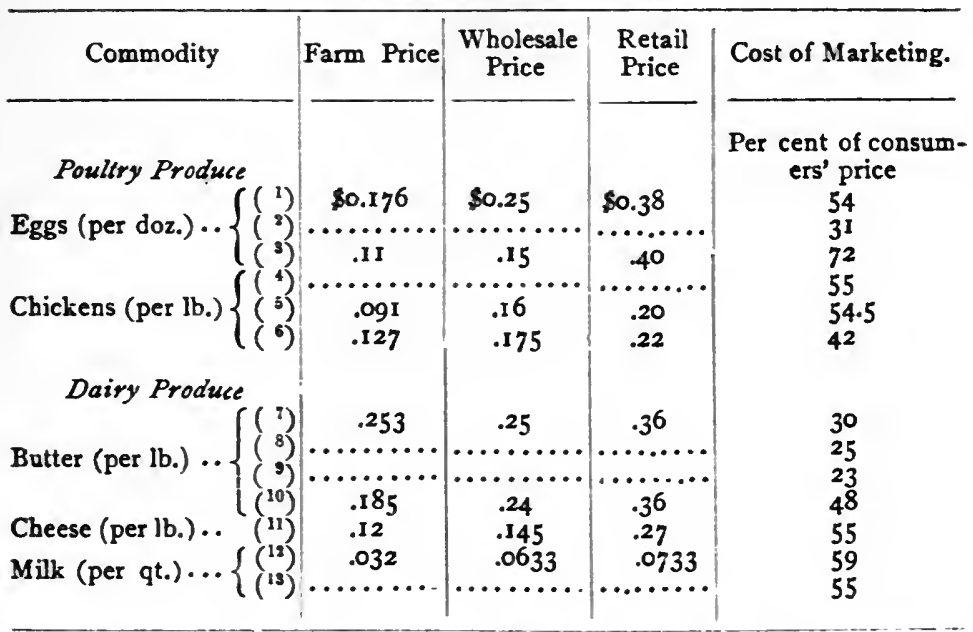

${ }^{1}$ Average farm price for July 15, 1914 estimated by the Dept. of Agri. Wholesale price for same date at New York as quoted by The Producers' Price-Current. Retail price same date in New York as estimated by Bureau of Labor Statistics. Bul. 156, p. 146.

3 Weld-Univ, of Minn. Studies in Soc. Sci., Bul. No.4, p. 7. This refers only to Minnesota eggs.

King-Philadelphia Markets in their bearing on the Cost of Farm Produce p. 13. In reference only to eggs produced near Philadelphia and marketed in Phila.

- Weld, op. cit., p. 7. In reference to Minnesota Poultry.

s Thomson-Univ. of Minn. Studies, Bul. No. 4, p. 72. Poultry marketed in the Twin Cities.

-Average farm price for Sept. 12, I9I4 estimated by the Dept. of Agri. Farmers' Bulletin No. 6II, p. 32. Wholesale price for same date at New York as quoted by the Producers' Price-Current. Retail price at New York on July I5, as estimated by Bureau of Labor Statistics Bul. No. 156, p. ${ }_{4} 6$.

'Secured the same way as prices for (6).

8 Bureau of Lab. Statistics, Bul. No. 164, p. II.

Weld, op. cit., p. 8. Marketing Minnesota butter in New York.

${ }^{10} \mathrm{King}$, op. cit., p. I3. Pennsylvania butter marketed in Philadelphia.

11 Univ. of Wis. Bul. 232, p. 30. Wisconsin cheese marketed in U. S.

${ }^{12}$ Calvert-Univ. of Minn., Bul. No. 4. p. 86. Cost of distributing milk by Minneapolis Milk Company, I912-'13.

12 Weld, op. cit., p. 7. Average for milk of Minnesota. 
TABLE VI-(Concluded)

The Cost of Marketing Perishables

\begin{tabular}{|c|c|c|c|c|}
\hline Commodity & Farm Price & $\begin{array}{c}\text { Wholesale } \\
\text { Price }\end{array}$ & $\begin{array}{l}\text { Retail } \\
\text { Price }\end{array}$ & Cost of Marketing \\
\hline Fruits & & & & $\begin{array}{l}\text { Per cent of consum- } \\
\text { ers' price }\end{array}$ \\
\hline Apples (per bbl.) $\{(2)$ & $\$ 1.66$ & $\$ 2.16$ & $\$ 5.95$ & $7^{2}$ \\
\hline & 1.45 & 2.75 & 3.78 & $6_{3}$ \\
\hline Pears (per bu.) $\ldots \ldots(4)$ & 2.16 & 3.04 & 8.36 & 74 \\
\hline $\begin{array}{l}\left.\text { Peaches (per bu.)..( }{ }^{5}\right) \\
\text { Berries }\end{array}$ & 1.17 & 1.82 & $5 \cdot 4^{6}$ & $\begin{array}{l}78 \\
65\end{array}$ \\
\hline Vegetables & & & 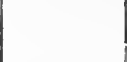 & \\
\hline Potatoes (per bu.) $\left\{\begin{array}{l}\left(\begin{array}{l}7 \\
8\end{array}\right) \\
(8)\end{array}\right.$ & $\cdots m_{815}$ & $\cdots \cdots \cdots$ & $\cdots \cdots \cdots$ & $\begin{array}{l}70 \\
45\end{array}$ \\
\hline Cabbage (per 100$\}\left({ }^{10}\right)$ & $\begin{array}{r}.53 \\
1.39\end{array}$ & $\begin{array}{r}.75 \\
2.38\end{array}$ & $\begin{array}{l}1.20 \\
4.17\end{array}$ & $\begin{array}{l}55 \\
67\end{array}$ \\
\hline lb.) $\ldots . . . \ldots \ldots\left\{\left({ }^{11}\right)\right.$ & $\ldots . .39$ & $\ldots . . .$. & & 47 \\
\hline $\begin{array}{r}\text { Tomatoes ( p e r }\left\{\begin{array}{l}\left({ }^{12}\right) \\
\text { pk.) } \ldots \ldots \ldots \ldots\end{array}{ }^{13}\right)\end{array}$ & $\begin{array}{l}.32 \\
.18\end{array}$ & $\begin{array}{l}.40 \\
.40\end{array}$ & $\begin{array}{l}.80 \\
.80\end{array}$ & $\begin{array}{l}60 \\
80\end{array}$ \\
\hline $\begin{array}{l}\text { Asparagus, lettuce, } \\
\left.\text { spinach, celery...( }{ }^{14}\right)\end{array}$ & $\ldots \ldots \ldots$ & & & 80 \\
\hline
\end{tabular}

1 Weld, op. cit., p. 7. Average for Minn. fruits.

' Farm price secured by taking average of farm prices given by Dept. of Agri. July to Dec., 1914. Wholesale price is gotten by taking average for New York for same period. Retail price is for New York in July as ascertained by personal investigation.

${ }^{3}$ Bul. 302, p. 8 of Dept. of Agri. For apples distributed through the five and ten cent stores.

${ }^{4}$ Different prices gotten same way as those for (2).

5 Different prices gotten same way as those for (2) and (4).

${ }^{6} \mathrm{King}$, op. cit., p. 13. For berries grown in Pennsylvania marketed in Philadelphia. Berries shipped from other states would show a much higher cost.

${ }^{7}$ Weld, op. cit., p. 7. Average cost for marketing Minnesota vegetables.

${ }^{8}$ Farm and wholesale prices gotten as in (2), (4), and (5). Retail price is the one for New York July 15, 1914 as given by Bureau of Lab. Statistics, Bul. $156 \mathrm{p} .140$.

${ }^{9} \mathrm{King}$, op. cit., p. 13. For local potatoes marketed in Philadelphia.

${ }^{10}$ Prices gotten in same way as in (2) and (4).

"Peterson-Univ. of Minn., Bul. 4, p. 94. Local cabbage marketed in the Central Market of Minneapolis.

${ }^{12} \mathrm{King}$, op. cit., p. 13. For local tomatoes marketed in Philadelphia.

${ }^{13}$ Average price for U. S. summer of 1914. Farmers' Bul. 620, p. 33. Com. bined with Philadelphia prices.

14 It is not possible to get figures because of the great fluctuation in the cost, but wholesale and retail men assert that the cost is much higher for this class of vegetable than any other. 
TABLE VII

Retall Prices of Food Products in American Cities Compared with those in Europzan Cities, July 1914

\begin{tabular}{|c|c|c|c|c|c|c|c|}
\hline \multirow{2}{*}{ Commodity } & \multicolumn{2}{|c|}{ American Cities } & \multicolumn{5}{|c|}{ European cities } \\
\hline & $\underset{\text { City }^{\prime}}{\text { New York }}$ & St. Louis ${ }^{2}$ & $\begin{array}{l}\text { Rbeims, } \\
\text { France }^{3}\end{array}$ & $\begin{array}{l}\text { Hamburg, } \\
\text { Germany }\end{array}$ & $\begin{array}{l}\text { Edinburgh } \\
\text { Scotland }\end{array}$ & $\begin{array}{l}\text { Genoa, } \\
\text { Italy }\end{array}$ & $\begin{array}{l}\text { Nor: } \\
\text { way }\end{array}$ \\
\hline Sirloin Steak (per lb.) .... & $\$ 0.27$ & $\$ 0.30$ & ..... & .357 & & $\ldots$ & .171 \\
\hline Round Steak (per lb.) .... & .27 & .25 & .16 & ........ & .26 & & \\
\hline Rib roast (per lb.) .......... & .22 & .20 & $\ldots \ldots$ & . $\ldots \ldots$ & $\cdots$ & & \\
\hline Chuck Roast (per lb.) ..... & .16 & .175 & $\ldots \ldots$ &.$\ldots \ldots$. & .16 & $\ldots \ldots$ & $\ldots \ldots$ \\
\hline Pork Chops (per lb.) ..... & .22 & .20 & $\ldots \ldots$ & $\ldots \ldots$ & .24 & $\ldots \ldots$ & .171 \\
\hline Bacon, Smoked (per lb.) .. & .25 & .30 & ...... & $\cdot \cdots \cdots$ & $\ldots \ldots$ & .20 & .18 \\
\hline Ham, Smoked (per lb.) ... & .30 & .30 & $\ldots \ldots$ &.$\quad .333$ & 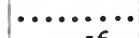 & $\cdot \cdots \cdots$ & ...... \\
\hline Lard, Pure (per lb.) ....... & .15 & .15 & $\cdots \cdots$ & ….... & .16 & .19 & $\cdots \cdots$ \\
\hline Leg of Lamb (per lb.) .... & .16 & .20 & .24 & .238 & .22 & $\ldots \ldots$ & .181 \\
\hline Hens, not drawn (per lb.).. & .21 & .20 & $\ldots \ldots$ & .18 & ........ & ....... & ..... \\
\hline Flour, wheat ( 25 lbs.) ..... & .80 & .80 & 1.375 & 1.185 & ......... & .875 & \\
\hline Eggs, strictly fresh (per doz.) & .36 & .23 & .24 & .312 & .36 & .23 & .262 \\
\hline Butter creamery (per lb.).. & .34 & .35 & .32 & .32 & .30 & .30 & .28 \\
\hline Potatoes, Irish (per lb.) ... & .03 & .02 & .02 & .01 & ......... & .01 & .015 \\
\hline Sugar (per lb.) $\ldots \ldots \ldots \ldots$ & .054 & .056 & .07 & .057 & .05 & .113 & .071 \\
\hline Milk, fresh (per qt.) ...... &.$\infty 9$ & .08 & .05 & .067 & $\cdots$ & .06 & .043 \\
\hline
\end{tabular}

${ }^{1}$ From Bulletin of the United States Bureau of Labor Statistics, Whole Number 156 Pp. 139-145.

Ibid., PP. 169-171.

${ }^{3}$ Bulletin of the United States Bureau of Labor Statistics, Whole Number 170, p. 34.

4 Ibid., p. 40.

5 lbid., p. 77 .

Ibid., p. 84 .

'I6id., p. 104. Based on the average retail prices from twenty different localities. 


\section{CHAPTER II}

\section{The Present System of Marketing Perishables}

IT was shown in Chapter I that the present system of marketing perishable farm produce is a great economic burden to society. Before we can attempt to make suggestions whereby the burden may be lessened, it is necessary for us thoroughly to understand this system. This chapter, therefore, will be devoted to an analysis of its complicated machinery and the cost of handling the produce as it passes from one stage to another on its way to the consumer. A thorough knowledge of the working of the system is necessary before we can intelligently discuss improvements in methods and ways of marketing perishables.

I. OUTLINE OF THE MACHINERY OF THE MARKET

There are three kinds of markets for perishables: ( 1 ) Growers' Local Markets; (2) Wholesale Markets; and (3) Retail Markets. ${ }^{1}$ There is, also, a distinct class of middlemen for each of these markets-Country Shippers, Wholesalers, and Retailers. Each class of middlemen performs a distinct work in getting the goods from producer to consumer. ${ }^{2}$

I. The work of the Country Shipper in the Growers' Local Market is to assemble perishables from the neighbor-

${ }^{1}$ Huebner, Agricultural Commerce, p. 12.

${ }^{2}$ A full discussion of the present machinery for marketing perishables is given in U. S. Dept. of Agri., Bulletins Nos. 266-267, and Report No. 98, pp. 9-17.

44 
ing farms at the nearest shipping point; then grade, pack and ship them to the wholesale markets. There may be several types of country shippers engaged in this work. The most familiar type is the country storekeeper who makes it his business to buy the produce from nearby farmers and ship it to some other country shipper or to a wholesale market. All farmers' coöperative associations are organized primarily to carry on the work of a country shipper. ${ }^{1}$ Then there are men who give their whole time to shipping farm produce and represent no one except themselves. There are other country shippers who are representatives of some other middlemen and buy for them. Some country buyers travel from place to place according to harvesting seasons, while others are permanently located. Whether the country shipper is an association or an individual, whether he represents the producer, a buyer, or himself, whether he travels or is permanently located, his work is essentially the same-that of assembling car-lots and shipping them to the wholesale markets."

2. The work of the wholesale market is to receive the large-lot shipments from country shippers and producers and to divide the produce into small lots and distribute it to the nearby retail market. Aside from the auctioneer, there are no less than four distinct types of middlemen engaged in wholesaling. First, there is the broker who acts as a "go-between" for the shipper and buyer. $\mathrm{He}$ accepts the produce when it arrives at the wholesale center and finds a buyer for it, for which he receives a "brokerage fee." $\mathrm{He}$ is an agent of the shipper and makes the sale only by consent of, and in the name of, the shipper. Then there is the commission man who accepts goods on

1 U. S. Dept. of Agri., Report on Conference on Marketing, p. 3.

2 King, Lower Lizing Cost in Cities, p. 50. 
consignment and disposes of them at what he considers the best advantage. He makes the sale in his own name and accounts to the shipper for his act. Another is the car-lot dealer who buys produce in large shipments (generally car-lots or more) and sells it in smaller quantities-his work is breaking the car-lot. He buys on his own account, and represents only himself-he is in business for profits, not commissions. The other middleman in the wholesale market is the jobber who buys in less than car-lots from shippers, brokers, commission men or car-lot dealers, (most often from the latter), and sells to retailers in small-lots. $\mathrm{He}$, like the car-lot dealer, represents only himself and works for profits. In actual practice it is hard to distinguish one kind of wholesaler from another. The broker may do commission business and buy produce as a car-lot dealer and sell as a jobber. ${ }^{1}$ Any one type of wholesaler may at times do the work of the other types.

All wholesale dealers specialize to a greater or less extent in the goods they handle. Some brokers and commission men handle only poultry products, others nothing but vegetables, still others only fruits. There is a still higher degree of specialization among car-lot dealers than among brokers and commission men. In the very large cities we have car-lot dealers who handle only one product: one will handle only strawberries, another peaches and another watermelons. Then there are others who deal in two or three different products. The butter and cheese dealer or the poultry and egg dealer is a good example of this class. Few car-lot dealers, even in the smaller wholesale centers, ever handle more than one general class of perishables. That is, we sometimes find one who buys and sells

${ }^{1}$ Men engaged in the wholesale business have assured the writer that this is the case. 
all kinds of fruits or all kinds of vegetables. When we come to the jobbers we do not find very much specialization. Any one jobber will generally buy and sell perishables of all kinds. In the smaller centers we will find occasionally that the jobber who sells perishables to the retailers sells them all other kinds of foodstuffs at the same time.

It must also be remembered that it is only in the very large wholesale centers that we find the wholesale trade divided up between brokers, commission men, car-lot dealers and jobbers. In the towns of less than I 5,000 inhabitants we generally find only one kind or type of wholesale dealers. Here all wholesalers sell directly to the retailers. Their work is almost identical with that performed by the jobbers in the large centers. Most of them buy their goods from brokers, commission men and car-lot dealers in the large centers just as do the jobbers. It is only when a town becomes large enough to receive car-lots directly from shippers that its wholesale trade begins to be divided up between different classes of wholesalers. In other words, we may safely say, the larger the wholesale center the more subdivision or specialization will be found among those who carry on the trade.

3. The object of the retail market is, of course, to sell to consumers. The retailer may buy his goods from farmers, country shippers, brokers, commission men, car-lot dealers, or jobbers-in the large cities he generally buys from jobbers. There are several types of retailers for perishables. The fruit and vegetable hucksters and vendors are familiar retailers in cities. Where municipal markets and consumers' coöperative stores exist, they also handle perishables, and chain stores, butcher shops and dairy companies sell a considerable proportion of some perishables. But the most common type of retailer of these goods is the corner-grocer who sells all kinds of food. 
II. COMPLICATIONS AND LACK OF UNIFORMITY IN

\section{MARKETING OPERATIONS}

The following example shows how some perishables pass from producer to consumer: Mr. Smith, a country collecting agent, goes from farm to farm in Cleveland County, Oklahoma, and buys eggs from the farmers. He sells them to Mr. Jones, a country shipper in Norman, the county-seat. Mr. Jones ships them to a large produce-shipping company in Oklahoma City. This company sends them in car-lots to New York to be sold by a broker, Mr. A. ${ }^{{ }^{2}}$ Mr. A sells them to a car-lot dealer, Mr. B, who in turn sells them to Mr. C, a jobber. They are sold by the latter to a retailer, Mr. D, who sells them to consumers.

While a large quantity of perishables marketed at great distance go through substantially the general course described above, there is no uniformity in the methods of marketing all perishables. A small percentage of them goes directly from producer to consumer, and another small proportion is sold by producers to retailers. Some individual growers send their produce to the wholesale market without the mediation of the professional country shipper. It is of interest to consider briefly the many methods and practices employed in marketing perishables.

Produce may pass from producer directly to consumer in the following ways: (a) by the farmer's "peddling" his produce from house to house as the "street huckster" does; (b) through municipal or public retail markets; (c) delivery to consumers by express or parcel-post; and, (d) sales to factories-such as canning and pickling plants and cider and grape-juice factories. ${ }^{2}$ It is only in cases where producer and consumer are in close proximity to each other

1 Traced by writer to the wholesale market.

'U. S. Dept. of Agri., Bul. No. 266, p. 9. 
that it is practicable for them to have direct dealings. As the markets have become wider and the commerce in the goods greater, a smaller and smaller percentage of perishables passes directly from producer to consumer-probably not more than one per cent of the total. The post-office department has recently waged an extensive campaign advocating the use of parcel-post to bring together widelyseparated producers and consumers. ${ }^{1}$ The parcel-post is now used to some extent by farmers in selling to large consumers, such as hotels, restaurants, etc. However, as we shall see, it has very serious limitations as an aid to direct marketing. The creameries, canneries, distilleries and factories are becoming the most important direct outlet for the producers of milk, grapes, apples, tomatoes, and some other special perishables-this is especially true of the western producers. ${ }^{2}$

There are a number of perishables which pass from farmers to retailers, who, in turn, sell them to local consumers. This kind of trade is confined principally to country towns which depend largely upon nearby farms to supply them with fresh produce. The merchant in this case saves the farmer from "peddling" his goods from houseto-house to find a market. Some of the produce which is sold in the municipal markets of small cities is bought by the vendors (or merchants) directly from farmers and sold to consumers. ${ }^{3}$ Many of the chain-stores are buying di-

1 The Postmaster-General has published several magazine articles adrocating such use of parcel-post. The Department has also published several pamphlets giving directions to producers as to the use of parcelpost. The Office of Markets of Dept. of Agri. has published bulletins on this subject-Buls. Nos. 594, 6II.

${ }^{2}$ U. S. Dept. of Agri., Bul. No. 266, p. I2.

${ }^{3}$ Carter. J. F., "Public Markets in American Cities," Report of Mayor's Market Commission of New York City, pp. 67-84. 
rectly from farmers, either by sending their wagons to the farms for the goods or having the farmers bring or ship them to the store. ${ }^{1}$ But, after all, sales to retail dealers by farmers probably amount to less in the aggregate than the amount sold to consumers directly.

There are a few large growers, and many farmers' cooperative sales associations which sell directly to the wholesale markets. In other words, they do not use the professional country shipper to get their goods to the wholesale centers. This, as we shall see, is possible only when they can ship in large lots and are able to employ expert knowledge in carrying on the operation. It is recognized by those who have given close study to farmers' coöperative sales associations that their greatest usefulness is in the possible reduction of the cost of getting goods to the wholesale markets. ${ }^{2}$ Much of the fruits and vegetables of the West and not a small part of the perishables of the South and East are shipped to the wholesale centers by these associations. As the situation stands to-day, less than half the fruits and vegetables and less than a fourth of the poultry and dairy products which arrive at our great wholesale markets are sent there by individual farmers or farmers' cooperative associations; ${ }^{3}$ the rest is sent by country shippers of various types.

Below are given the methods employed in marketing particular perishables in the United States as described by the Department of Agriculture:

${ }^{1}$ King, Lower Living Costs in Cities, p. 94.

' Powell, C. H., Yearbook roro, pp. 39I-406.

${ }^{3}$ Wholesale men in New York City assure the writer that this is an over-estimation of the shipments of growers and coopperative associations. 


\section{Marketing Butter}

(U. S. Department of Agriculture, Report No. 98, pp. 37-38.)

More than half of all the butter produced in this country is dairy butter. The market for this class of goods is found, first, in the grocery stores of the villages and of the smaller cities throughout the country; second, in direct sales to private families, hotels, and boarding houses; and third, through commission houses. Usually the best of the butter sold to the grocery stores is afterwards sold to consumers and the rest is shipped to renovated-butter factories, ladling establishments, and commission houses, from which it later finds its way to the consumers through the retailers.

Of the various methods of marketing used by creameries it is probable that "sales on contract" is the most popular. Factories using this method have a contract, or at least an understanding more or less binding, with one or more firms or merchants as to the price they are to receive for the butter. This contract price is based on the official quotation of some market. Many creamery managers sell on orders direct to dealers, both wholesale and retail. Others are still marketing through commission houses-ship on consignment-and still others have a local or home trade. The wholesale dealersbrokers and commission men-and the retailers constitute the " middlemen"; that is, they are the links between the creameries and the consumers.

In the larger cities the wholesale dealers maintain a board of trade where butter, cheese, and eggs are sold or offered for sale daily. In the main, there is but little difference in the management of these boards. They are completely controlled by the members who constitute the membership. From time to time, rules and regulations for the conduct of business on the board are issued, qualities defined and grades established. These rules as well as the classifications are changed whenever the interests of the board (the dealers) demand it. The producers have no voice whatsoever in anything that transpires on these boards. 
A butter inspector is employed by the board. Whenever there is a dispute as to the quality of a shipment of butter or a refusal to accept it upon the part of the buyer the inspector may be called, and it is then his duty properly to classify the goods in accordance with the regulations of the board. Generally speaking, however, the board classification is not recognized in ordinary business transactions, for it is generally high in its requirements. It is only when there is some special reason for using it, that it is invoked. When practical the merchants ignore it when they sell to retailers. Formerly it was the custom to quote, or in some way establish, a price each day when the board was in session. Generally, a quotation committee had this matter in charge. For certain reasons, this practice has been abandoned by most of the boards. The sales on the board are now in the main relied upon to establish the price. As a rule the transactions are small and, although bona fide, are in reality merely an expression of the dealers as to what they desire the price to be. To this statement there may be an exception in the case of held or storage goods. But this class of produce is nearly always the property of dealers when offered for sale and has long since been paid for, while in the case of "fresh arrivals" the price established affects large quantities of butter which the merchant has not yet settled for and which in reality still belong to the producer or manufacturer.

The storing of butter is done chiefly by wholesale dealers. As a rule, the largest firms store the greatest amounts. Some of them have their private cold storage, while others use the public plants. These latter also furnish storage facilities to the smaller dealers and speculators. Some of the retailers also store butter-enough for the demand for their own trade during winter or the period of greatest scarcity.

The prevailing prices are given wide publication and the farmers or manufacturers who wish to do so can readily learn what they are. However, the farmers have no voice or influence in the establishment of these prices nor have they any means of knowing whether or not the prices quoted are artificial 
or out of harmony with existing market conditions. An attempt at coöperative marketing of butter has been made by a number of creameries in Minnesota, but so far as is known little or no good has come from it. No doubt the difficulties in the way of success of such an undertaking are, first, lack of business experience, upon the part of the farmers and their creamery managers; second, insufficient capital ; third, a natural disinclination upon the part of the farmers to cooperate with one another.

\section{Marketing Apples}

(U. S. Department of Agriculture, Report No. 98, pp. 53-54.)

Probably the largest part of the crop is bought "on the trees" delivered on the packing table, or "f. o. b. cars," immediately before or after harvest. by representatives of large fruit receivers or brokers and shipped direct to their home markets, distributed to jobbers or agents in other market centers, or put into cold storage. The next larger portion of the crop is shipped by the grower to commission houses in large cities. Practically all of this crop, except a very small portion from California and some of the Northwestern States, which is sold at auction in the larger cities, is disposed of at private sales either in the cars, unloaded at terminals of the transportation companies, or at the receivers stores. Last year an innovation was introduced by one of the largest brokers in New York City, who sold consigned lots of Hudson Valley apples in barrels at public auction, and it is understood very satisfactory results were obtained. Jobbers and fruit brokers were the purchasers at those sales as at the citrus auctions.

There are several instances of growers disposing of more or less of their crops direct to consumers or retailers in nearby markets. Such deliveries are usually made by team, and are therefore limited in extent of territory covered. Some such shipments are by express and local freight on steam or suburban electric railroads. If, as seems to be probable, the limit of weight of parcels-post shipments shall be increased, a large 
field will be opened to the fruit grower for the shipment of his product direct to consumers.

\section{Marketing Eggs}

(U. S. Department of Agriculture, Report No. 98, pp. 48-49.)

At the present time the common method of marketing eggs in the Middle West is, in brief, as follows: The farmer gathers his eggs whenever convenient, sometimes each day, sometimes two or three times a week. The eggs are brought to the house and kept until there is a sufficient number to take to the village or until the farmer makes a trip to the village for some other purpose and takes the eggs along. ... These eggs the farmer takes to the village store and receives for them a certain price per dozen, which is usually given in trade. . . . The merchant holds the eggs till he has enough to make a shipment to some egg dealer or shipper from whom he gets regular quotations. The delay here may be anywhere from two days to a week, or even two weeks.... After they reach the packing house they are assembled in great enough numbers so that more attention and care is given their handling, and although the eggs go through one or more sets of hands from this point before they are placed in storage or reach the consumer the deterioration which they undergo is usually not so great proportionately.

In a few sections of the country producers sells eggs cooperatively.

In addition to the large output of eggs which enters commerce, there is, of course, a very large trade from the producer direct to the consumer. Small poultry keepers and truck gardeners are found in all cities at the central markets with eggs of their own production. And many of these people do a house-to-house business. 


\section{Marketing Cabbage}

(U. S. Department of Agriculture, Report No. 98, pp. 161-162.)

The description given below of marketing cabbage will apply equally well to the methods of marketing most vegetables, potatoes and a good many fruits-such as peaches, canteloups and berries.

Cabbage, like Irish potatoes, must be considered from the standpoint of a perishable truck crop and from the standpoint of a farm crop. As a truck crop cabbage is very extensively grown, but it is almost entirely handled on a consignmentshipping basis. It is seldom or never bought in the field unless the selling agency maintains a representative in the field who buys and ships. The only exception is to be found in the association ... in the eastern shore of Virginia, where cabbage, as well as Irish and sweet potatoes, is handled under cooperative arrangement. At the present time there are no safeguards to this industry. There is no provision for using a surplus when prices are low, and as a result losses are not infrequent.

With the farm crop, which is distributed widely throughout the Northern States from Colorado to Maine, the crop is handled quite differently. In a few instances growers have provided themselves with store-houses in which to hold the crop, but as a rule it is marketed direct from the field, loaded in cars, and shipped to consuming points chiefly by local buyers, who in some instances are provided with large warehouses in which a portion of the crop is stored and held for later distribution. The result is that the dealer rather than the grower reaps the reward of any improvement in the market. In other localities the crop is marketed directly from the field at kraut factories. This constitutes another type of local sale frequently made within the limits of the wagon haul, but sometimes the crop is loaded and shipped short distances to the kraut factory. 
III. COST-FACTORS OF THE MIDDLEMAN SYSTEM

What does each type or class of middleman receive for his work and what are his necessary expenses? What is the actual cost of each function or operation which he performs? Are his profits excessive or is the high cost of marketing due to defects in the system? These questions can be answered only by investigating the necessary expenses which each type of middleman has in carrying on his work, and by comparing these with what he receives for his work. In analyzing the expenses necessary to the carrying on of the middleman's operations, we shall approach the problem as we would one of cost-of-production in manufacturing or in agriculture. Marketing, after all, is a part of production-time and place production-and the cost factors are essentially the same. Our method will be to start with the goods as they leave the producer (cost of raw material) and find the necessary (running and overhead) expenses of putting them in the hands of the consumer (as finished products).

I. The work of hauling produce from farm to market must be performed by the farmer himself or by some middleman. If the farmer hauls his own produce to market, he must deduct the cost from the price he receives at the market in order to arrive at the real "farm price". In other words the hauling of farm products from farm to the local market is a part of the cost of marketing. In cases where middlemen go to farms to buy goods and carry them to market no one could doubt that the hauling constitutes a part of the cost of marketing. Let us see what part this factor plays in making the whole system costly.

The factors which affect the cost of hauling any unit of farm produce from farm to market are: (a) cost of team and driver per day; (b) distance to market; (c) con- 
dition of road; (d) size and value of each load; and, (e) effect of the haul on the goods themselves. Needless to say, these factors vary greatly with sections, seasons, individuals, and kind of produce. It is hard to say which of the factors is of greatest importance, but certainly, the condition of the road is not the least of them. It determines in a large measure the size of the load and the distance (in time) to market as well as the effect of the haul on the goods. The "good-roads" enthusiasts are right in maintaining that improvement in roads will greatly lessen the cost of the farmer's haul to market. But, after all, the other factors are not overshadowed by the good-roads question.

The average value per day of a farm team and driver is about $\$ 3.50{ }^{1}$ But most perishables, unlike staples, are marketed by farmers at growing seasons when their own time and that of their teams is very valuable for purposes of agricultural production. So when they stop to make a trip to the local market it may cost three or four times as much as it would at some other season. The average load for staples is about 2,000 pounds, ${ }^{2}$ but because of their bulkiness the average load for perishables is about 1,000 . Then, too, on the average, the specific value of perishables is lower that that of staples, so a load of perishables is much less valuable than one of staples. The average farm-haul in the United States is about 6.5 miles:" permitting about two trips from farm to market in a day. Because of the character of the perishables themselves, and because the average farmer provides little protection for them from the weather their deterioration during the trip is usually con-

${ }^{1}$ Farmers' Bulletin No. 672, p. I3.

Ilbid., p. I4.

Ibid., p. Ir. 
siderable. In many cases farmers start with perfectly fresh and sound fruits and vegetables but expose them to the blazing sun or freezing wind on the road until they are in a very bad state when the destination is reached. The amount of actual decay from this cause cannot be accurately estimated, but it is much greater than the average man would think.

The best estimates of the cost of hauling perishables to market (not including deterioration of goods) are as follows: The average cost for hauling all farm produce to market is about eleven cents per hundredweight. ${ }^{1}$ For vegetables and fruits it is about fifteen cents, ${ }^{2}$ and for dairy and poultry products the cost is much more because the average load is small. Professor King says, "It costs as much to haul a ton of the average farm product one mile as to send it by steam rail 300 to 500 or even I,000 miles." ${ }^{3}$ While the farm haul costs about ten per cent of the farm - value of corn, it costs not less than twenty per cent of the farm value of vegetables and fruits. ${ }^{4} \mid$ So it is clear that a very great part of the cost of marketing perishables is due to the high cost of getting them from farm to market. In a later section we shall discuss the possibilities of reducing this cost.

2. As we have seen, the work of the country shipper is to assemble the produce at the local shipping point and send it in large lots to the wholesale markets. What are his necessary expenses? First, he has his overhead charges of capital investment in storage, and office facilities as well as wages for himself and permanent assistant. These ex-

1 King, Lower Living Cost in Cities, p. 32.

"Philips, S. A., Annals of Amer. Acad. of Pol. and Soc. Sci., Nov. I9I3, p. 21.

3 King, op. cit., p. 32.

4 Philips, op. cit., p. $2 \mathrm{r}$. 
penses must be met whether business is good or bad. Second, are the variable or running expenses. The running expenses of the local shipper are as follows: (a) grading and packing; (b) storing until shipping lots are assembled; (c) getting a market; (d) shipment; (e) loss from deterioration of goods; (f) financing the sales.

(a) Few farmers know or care anything about grading and packing the produce they sell. One dozen eggs is, to most of them, equal to any other dozen regardless of differences in age, color, size, or previous state of exposure to decay. As a rule, they bring their produce to market without separating good from bad. So the country shipper is forced to grade and pack it before shipping it to the wholesale market. As we shall see later, there is little uniformity in either grades or packages sent to the wholesale centers by shippers, in spite of the fact that they spend considerable money on each shipment in grading and packing. However, if they do not grade and pack the produce before shipping they will receive a much lower price.

(b) Shippers must provide storage for goods until enough is assembled for shipment. For most perishables, this necessarily means facilities for pre-cooling and refrigeration. Such requirements involve, not only the overhead charges of storage room. but the current expenses of icing and manual labor for placing goods in storage and taking them out again. Unfortunately, however, few country shippers have adequate facilities for pre-cooling and refrigeration.

(c) The most difficult, if not the most expensive, work the shipper performs is that of finding a market for his produce. There is to-day no organized market or marketnews for perishables as there is for staples. Every daily paper carries full market news for cotton or wheat, but it is not easy to get information in regard to the market for other 
farm produce. There is no accurate record of receipts of perishables in trade centers, and the price quotations are known only locally. ${ }^{i}$ For getting what little information there is to be had, a shipper must spend a great deal of money on telegrams, telephone calls and night letters. ${ }^{2}$ It often happens that a market will be short on certain produce one day and the price will be very high, while the next day the receipts of that produce will be so large that the price will be very low. ${ }^{3}$ Also, one market may be "glutted " with peaches or some other perishable and the prices consequently very low, while on the same day these articles may be very scarce in another market and price quotations high. On this point Farmers' Bulletin No. 266 says, "The constant fluctuation in market prices make it absolutely necessary for the shipper to keep in constant touch with the markets by correspondence or otherwise if he expects to receive full value for his goods." "

In addition to knowing where to ship his goods, the shipper must know who is to receive them. Some one must accept the goods at the wholesale center, see that they are cared for and disposed of at the best possible prices. So the shipper sends his goods to some wholesale merchant who buys them outright, or to some broker or commission man who will sell them for him. The business correspondence with these men (and there must be several of them for the ordinary shipper, as he will ship to several different markets) is no small item of expense and may be counted as an important part of the cost of finding a market.

${ }^{1}$ Records of receipts cannot be accurately kept because the produce is not shipped in uniform packages.

${ }^{2}$ The California Fruit Growers' Exchange spends $\$ 75,000$ per year for market information (U. S. Dept. of Agri., Report No. 98, p. 28).

${ }^{3}$ See table ii, p. 36.

4 Supra, p. 3. 
(d) Transportation is of such importance in the marketing of perishables that we have reserved it for separate discussion in this chapter. It is a problem, however, which is to be dealt with by the shipper. He must decide how he will ship the produce (whether by water or rail freight, express, or parcel-post), the size of the shipment, whether or not it shall go under refrigeration, and similar questions. He must also be able to prevent the transportation companies from discriminating against goods shipped from his section. He pays the cost of transportation and his goods must compete with those of other shippers who probably get cheaper rates. In fact, the country shipper should be an expert on questions of shipping. His ability to deal with these questions will not only largely determine the cost of carrying on his business, but also the soundness and value of his goods when they arrive at the wholesale markets.

(e) The next expense which the country shipper must undergo is the deterioration of his goods. This loss will be in inverse ratio to his ability to find a ready market and to ship to that market under the most favorable conditions for the safety of the produce. If he is compelled to keep his perishables a long time before finding a market, the loss from decay will grow even though he has the best means of taking care of them. But if they are exposed to the weather before they reach the terminal market the loss will grow still larger. As a matter of fact, the rejection of perishables at terminals because of decay is considerable. ${ }^{1}$

(f) The financing of a country shipper's business is a considerable undertaking. He generally pays cash to the farmer upon the receipt of produce, whereas he rarely receives payment for it until after its arrival at the wholesale

${ }^{1}$ In some cases the total shipments are lost, and the loss is not infrequently as much as 30 or 40 per cent. (Farmers' Bulletin No. 267, p. 23.) 
market. ${ }^{1}$ So his money is invested in each shipment for a considerable time (from one to eight weeks). In order to finance these operations most shippers are compelled to borrow money from banks at a fairly high rate of interest. These interest charges must be counted as a part of the cost of doing the business.

After deducting the cost of transportation to the wholesale market the average country shipper handles goods on a margin of about Io per cent ${ }^{2}$ - that is, he pays the farmer 90 per cent of what he gets for them after deducting transportation costs. (The above is only an average. Some shippers get a very much larger margin, ${ }^{3}$ and the margins on different shipments vary greatly with each shipper.) Considering the work, expenses and risks involved in his business under the present conditions it is certain that the average shipper does not make fat profits. It is only because he handles goods in large quantities that he is able to do business on such a small margin.

${ }^{1}$ A shipper may sell his produce either at his own shipping point, in transit, or at point of destination. When he sells at point of origin he may sell for cash out-right from his storehouse and let the buyer attend to loading and shipping (the professional shipper rarely does this), or he may sell f. o. b. point of origin with or without inspection privileges at destination. When this privilege is not given, the shipper gets his money upon delivering the goods in car upon track, otherwise he does not get his money until the goods arrive at destination and are inspected by the buyer. Where goods are sold in transit the shipper does not get the money for his goods until they are received and inspected, and this is also the case when he sells at point of destination. So in many cases the shipper does not get pay for his goods until several weeks after he has bought them.

2 King, op. cit., p. 19.

${ }^{3}$ The more highly perishable the produce the greater the margin. When goods are handled in small quantities the margin is greater. Then some shippers revert to unfair methods occasionally to get the produce from the farmer at very low prices in order to increase their margins. We shall speak of these unfair practices in another chapter. 
3. All methods of transportation by water and railfreight, express and parcel-post-are used in shipping perishables, but some more extensively than others. A comparison of their relative advantages will show us why some methods are preferable to others.

Water-rates on car-lots of perishables are, on the average, about two-thirds those of rail-freight between the same two points. ${ }^{1}$ Nevertheless, it is safe to estimate that not more than five per cent of the perishables which arrive at the wholesale markets are brought by boat. ${ }^{2}$ The reasons for the relatively small use of boat service in transporting perishables are: slowness of traffic, control of inland and interstate boat service by the railroads, and lack of development of inland water-ways in this country. Water transportation should play a much larger part in carrying on the traffic in these goods, and it probably will in the future.

As to whether shippers elect to use freight, express or parcel-post depends largely on the size of their shipments. The advantages which express and parcel-post possess over freight is that they transport small packages in shorter time and deliver directly to the receiver. On the other hand, freight rates are much cheaper than either express or parcel-post, and goods may be sent in much larger quantities. Parcel-post is only intended for the shipment of small packages - the maximum weight being fifty pounds for first, second and third zone and twenty pounds for the eighth zone, with a very definite limit on the dimensions of the package in each case. ${ }^{3}$ There is no refrigeration connected with the service, so perishables will deteriorate greatly if shipped long distances by this method. The goods are

\footnotetext{
1 U. S. Dept. of Agri., Bulletin No. 74, pp. 32-33.

2 Ibid., pp. 14-15.

3 See table of parcel-post rates, p. 74 .
} 
handled and re-handled so many times that exposure and breakage by parcel-post is considerable. But the greatest objection to this means of shipping is the high rate as compared with freight rates. One or two examples will make this apparent. To send Ioo pounds of apples by parcelpost from Memphis, Tennessee, to St. Louis would cost \$4. I 5 and the apples would have to be put in five separate packages, whereas, the freight rate would be only 25 cents. ${ }^{1}$ One hundred pounds of eggs sent by parcel-post from Hartford, Conn., to New York City would cost \$1.08, but the freight rate is only 35 cents. It is evident that there can be no competition between freight and parcel-post for great distances even with comparatively small shipments-and it would be absurd to think of sending a great quantity by parcel-post in several small parcels. So the usefulness of parcel-post as a means of transporting goods is very limited. (We shall speak later of the limited service it can hope to perform.)

It is hardly necessary to discuss the relative advantages of shipping by freight or express. The express rates are, on the average, a little higher than those of parcel-post for small packages. ${ }^{2}$ But the size of an express package is relatively unlimited and the rate per pound becomes less as the size of the package is increased so it is generally cheaper to send fifty pounds or more by express than by parcel-post. Recently express companies have installed refrigeration for perishable packages and have reduced the rates on most perishable commodities, changes which have caused an increase of their traffic in these goods. ${ }^{3}$ But, after all, the

${ }^{1}$ Compare freight rates with those of parcel-post given in tables, pp. 74-75.

${ }^{2}$ This is especially true for short hauls.

${ }^{3}$ This change was made in order to compete with parcel-post. 
total amount of perishables carried by express and parcelpost is insignificant as compared with that transported by rail-freight. Freight gives a much cheaper means of transportation for long-haul large-lot shipments, aside from its other advantages over express and parcel-post.

In order to get the greatest benefit from freight transportation the shipper must ship in car-lots. The advantages of the car-lot over the less-than-car-lot shipment are: (a) cheaper rates per unit; (b) better protection to the produce; (c) diversion of shipment privileges; and, (d) inspecting in transit privileges. It will be of interest to discuss briefly each of these advantages.

It is not necessary to say much in regard to the difference in rates between car-lot and small-lot shipments. The table on page 75 which gives a comparison of these rates between selected points speaks strongly enough on this point. It will be noticed that the rate per hundred pounds on car-lots is, on the average, about two-thirds that on the same unit for less-than-car-lots. ${ }^{1}$

Perishables transported in less than car-lots generally receive less care while in transit than do car-lot shipments, and thus arrive at their destination in a much more decayed condition. When shipped in small quantities goods are often transferred from one car to another while en route. This exposes them to varying heat, cold, wind, and moisture which cause much deterioration. Because of these many changes and transfers the small-lot shipments are, also, on the road a much longer time than car-lots which go straight through in the same car. Again where several

1 It might be added that a shipper who ships in small quantities finds it hard to get wholesale men to handle his produce at the wholesale centers at a reasonable cost. The commission man is about the only one of them who will handle it, and he charges a commission of about ten per cent. 
car-lots of the same class of perishables are shipped from one section to another the railroads bring all these cars together into train loads and send them by fast freight. ${ }^{1}$ But the broken-lots must be sent by slower freight.

It is very hard for a shipper of small quantities to get refrigerated or ventilated car service. The number of such cars at the disposal of the transportation companies is limited so that during the busy season the car-lot shippers press them into service and leave few or none for the small shippers. Refrigeration adds from five to ten per cent to the cost of transportation, but, with many perishables shipped without it, the loss from decay would be several times the cost of the refrigeration. ${ }^{2}$

There is no one thing which does more under present conditions to equalize supply and demand in the marketing of perishables than the "diversion of shipment " practiced by car-lot shippers. We have noticed that the receipts and prices at any one wholesale center vary greatly from day to day. In fact, the price variations are so great that a shipper who sends a car of peaches from Georgia to New York to be sold upon arrival is unable to estimate in the neighborhood of what the price will be when the peaches arrive there to be sold, even though he knows definitely the New York price for peaches the day he ships them. Upon such shipments he simply takes a gambler's risk. It is to reduce this risk that the railroads allow the "diversion" privilege. Under it a shipper can start his car of peaches, apples or any other perishables as a "tramp car" in the general direction of the great wholesale markets of Washington, Baltimore, Pittsburg, Philadelphia, New York, and

${ }^{1}$ Andrews, Annals of Amer. Acad. of Pol. and Soc. Sci., Nov. 19r3, pp. I-9.

2 Pennington, Mayor's Market Commission Report of New York City, pp. 252-253. 
running expense except that of finding a market. His overhead expenses need not consist of more than office room with telephone service and his own wage of management. Brokers rarely handle produce in less than car-lots, ${ }^{1}$ so their expense per unit of produce handled is very small. For their services they charge from two to five per cent on the gross sales after deducting transportation charges.

Shippers consign goods to commission men who, unlike brokers, make the sales in their own names without consulting the shipper (however, if they receive specific instructions from the shipper they are compelled to obey them). ${ }^{2}$ Commission men accept less-than-car-lots as well as car-lots. They often store received goods for a better market, and not infrequently they re-grade and re-pack them. All expenses of storage, refrigeration, re-grading and re-packing are charged up to the shipper when the commission man makes his "account sales" to the shipper, nevertheless, the time and trouble of seeing that the goods are so cared for is an overhead expense to the commission merchant. Sales are made to car-lot dealers, jobbers or to retailers-on the average he sells in much smaller quantities than do brokers. Though the capital investment of the commission man is not necessarily much greater than that of the broker, his expenses of doing business per unit of produce are much greater, because he handles goods in much smaller quantities and accepts more responsibilities in disposing of them. After deducting freight. storage and other direct charges on the goods he generally receives a commission of ten per cent ${ }^{3}$ on sales.

1 Farmers' Bulletin No. 267, p. 14.

${ }^{2}$ Ibid., p. I8.

3 Ten per cent for fruits and vegetables and five per cent for butter, cheese, eggs and poultry. (Urner, Annals of Amer. Acad. of Pol. and Soc. Sci., Nov. I9I3, p. 70. 
The car-lot dealer, like the retailer, buys goods with the expectation of selling them again at a higher price-the difference between the two is that the former buys and sells in large units, and the latter in small units. In order to carry on his business the car-lot dealer must have a considerable capital investment: he must provide storage, refrigeration and packing rooms aside from office facilities and cash for investment in goods. His running expenses are somewhat as follows: cartage from car to storage house, re-packing and re-grading, finding a market, delivery of the goods in quantities sold, losses from decay and crediting the buyer. Under present terminal facilities and location of warehouse the cartage expense is very great for the average shipment of perishables. ${ }^{1}$ Because of the absolute lack of uniformity in size, weight and grade of packages sent to the wholesale centers to-day, and of the decay of the produce while in transit and after it reaches the terminal, the re-grading and re-packing carried on by wholesale dealers adds considerably to the cost of doing business. ${ }^{2}$ Finding a favorable market is no small work for the car-lot dealer. He sells in broken lots to jobbers and retailers, so the number of customers he has is considerable. In order to dispose of his produce to the best advantage he often has to keep it on hand a considerable time-this is especially true when the market is glutted. When sales

1 Mayor's Market Commission Report of New York City, p. I7.

${ }^{2}$ As it is to-day, each section of the country, and almost each shipper, has a different sized package and different standards of grades. Each fruit and vegetable (apples excepted) now enters the wholesale markets packed in from 3 to 25 different sized containers, to say nothing of the diversity of grades. The retail trade demands some standardization in both grade and package, consequently the produce must be re-graded and re-packed in the wholesale markets. (See Lippman, Mayor's Market Commission Report of New York City, pp. I39-145.) We shall speak later of the possibilities of standardizing these grades and packages. 
are made, the breaking-up of the car-lots and delivering the goods in small quantities entails a good deal of physical work for each car. The car-lot dealer's losses from decay and from poor grades are considerable. Again he often sells to jobbers and retailers on a credit which further increases his expenses of doing business. So, considering all his work, the car-lot dealer's total expenses are considerable. But, after all, the expense per unit of goods he handles is surprisingly low-he seils on an average margin of from five to seven per cent. ${ }^{1} \mathrm{He}$ is enabled to handle goods on such a small margin only because he handles them in such large quantities.

The jobber also buys goods outright with an expectation of selling them at an advance in price, and his work is no less complicated than that of the car-lot dealer. He buys "broken-lots" of all kinds of perishables from the latter or from commission men and sells them immediately to retailers, hotels and restaurants. In performing this work he occasionally re-grades and re-packs in order to suit the taste of his various customers. His expense of finding a market is rather high per unit of produce, for, in many cases, business is gotten by sending "drummers" into the retail field. He often gives the buyer from thirty to sixty days credit and thus subjects himself to losses from bad debts. His capital investment in goods and in storage facilities is not necessarily lazger, as he often has goods sold before he has actually bought them. So his "turn-over" of capital is rapid. He does business on about a five per cent margin.

As has been stated, few goods which pass through the wholesale market are handled by all four classes of wholesale dealers-it seldom happens that more than three handle

${ }^{1}$ Estimated by writer from conversation with car-lot dealers. 
any one particular commodity. Taken as a whole, the prices of perishables are increased about ten per cent as they pass through the wholesale market to the retailer. ${ }^{1}$

The retailing is the most expensive part of marketing perishables. It is shown in Tables VI and VII ${ }^{2}$ that the retailer does business on about a forty-five per cent margin, which is greater than the combined cost of getting the produce from farmer to retailer. The work of the retailer is so well known and has been so excellently discussed by Professor Paul H. Neystrom in his recent book on The Economics of Retailing that it is unnecessary to give a detailed discussion here. In another section of this work, we shall suggest needed reforms in the retailing business.

IV. DISTINCTION BETWEEN MIDDLEMAN NACHINERY AND ITS OPERATORS

As contradictory as it may seem at first, marketing perishables through the middleman machinery does not necessarily depend on the employment of private middlemen to carry on the work purely for their own personal benefit or profit. In running the " machinery " farmers' coöperative marketing associations may, and at present in some cases do, take over the work ordinarily performed by private country shippers of assembling the goods and shipping them to the wholesale market. ${ }^{3}$ It is conceivable that municipal wholesale markets could take over the wholesale machinery and do the work which is now practically universally performed in the United States by private wholesale dealers. In the European countries the municipalities do perform a considerable proportion of this work. ${ }^{4}$ The retailing part of the machinery might be carried on by consumers' coöperative
1 King, Lower Living Cost in Cities, p. 20.
2 Pp. 41-43.
${ }^{3}$ Coulter, Coöperation among Farmers.
4 Mayor's Market Commission Report of New York City, p. 85. 
stores, or by municipal retail markets, rather than by private retailers. In England, consumers' coöperative stores have taken up this work on an extensive scale, ${ }^{1}$ and on the continent of Europe retail municipal markets are important agencies in carrying on this work. ${ }^{2}$ It is further conceivable that the whole machinery of the system could, under socialism, be taken over by the National Government and run as the Post Office is now run. What we call the middleman machinery is the machinery for, and methods of, assembling goods at the shipping point, shipping them to wholesale markets, distributing them in wholesale markets to retailers, and from retailers to consumers. In short, the middleman machinery is the methods of getting goods from producers to consumers, not the agents which perform these functions. The agents may be changed from private individuals to corporations, to coöperative associations, to governments or to divisions of governments and the machinery in its essential points remain the same. The word "middleman" has been applied to this particular machinery because it was organized by private traders who were known by that name.

So in discussing the middleman system of marketing perishables there are two fundamental questions with which we have to deal. First, what are the inherent strong and weak features of the middleman machinery? Second, who should run the machinery-private middlemen, coöperative associations, the government, or all-and what regulations should be thrown around the operators? The practical detailed workings of the system are so affected by the character and type of the operators that it is not possible to disregard entirely the second question in discussing the first.

1 Sen. Doc. No. 214, 63d Cong., Ist ses., pp. 773-81.

2 King, p. I22. 
Parcel Post Rates in the United States

\begin{tabular}{|c|c|c|c|c|c|c|c|c|c|}
\hline $\begin{array}{l}\text { Weight } \\
\text { in } \\
\text { pounds }\end{array}$ & Local & $\begin{array}{c}\text { rst } \\
U_{p} \text { to } 50 \\
\text { miles }\end{array}$ & $\begin{array}{l}\text { 2d } \\
50 \text { to } 150 \\
\text { miles }\end{array}$ & $\begin{array}{c}3 \mathrm{~d} \\
150 \text { to } 300 \\
\text { miles }\end{array}$ & $\begin{array}{c}4^{\text {th }} \\
300 \text { to } 600 \\
\text { miles }\end{array}$ & $\begin{array}{l}5^{\text {th }} \\
600 \text { to I000 } \\
\text { miles }\end{array}$ & $\begin{array}{l}\text { 6th } \\
1000 \text { to I } 400 \\
\text { miles }\end{array}$ & $\begin{array}{l}\text { 7th } \\
1400 \text { to } 1800 \\
\text { miles }\end{array}$ & $\begin{array}{c}\text { 8th } \\
\text { Over I } 800 \\
\text { miles }\end{array}$ \\
\hline I & $\$ 0.05$ & $\$ 0.05$ & $\$ 0.05$ & $\$ 0.06$ & $\$ 0.07$ & $\$ 0.08$ & $\$ 0.09$ & $\$ 0.11$ & $\$ 0.12$ \\
\hline 2 & .06 & .06 & .06 & .08 & .I I & .14 & .17 & $.2 \mathrm{I}$ & .24 \\
\hline 3 & .06 & .07 & .07 & .10 & .15 & .20 & .25 & .31 & .36 \\
\hline 4 & .07 & .08 & .08 & .12 & .19 & .26 & .33 & .41 & .48 \\
\hline 5 & .07 & .09 &.$\infty 9$ & .14 & .23 & .32 & $.4 \mathrm{I}$ & .51 & .60 \\
\hline 6 & .08 & . IO & .10 & .16 & .27 & .38 & .49 & .61 & .72 \\
\hline 7 & .08 &. $\mathrm{II}$ & . II & .18 & .31 & .44 & .57 & $.7 \mathrm{I}$ & .84 \\
\hline 8 & .09 & .12 & .12 & .20 & .35 & .50 & .65 & .81 & .96 \\
\hline 9 & .09 & .13 & .13 & .22 & .39 & .56 & .73 & .91 & 1.08 \\
\hline IO & .10 & .14 & .14 & .24 & .43 & .62 & $.8 \mathrm{I}$ & 1.01 & 1.20 \\
\hline II & .10 & .15 & .15 & .26 & .47 & .68 & .89 & 1.11 & 1.32 \\
\hline 12 & . II & .16 & .16 & .28 & $.5 \mathrm{I}$ & .74 & .97 & 1.21 & 1.44 \\
\hline I 3 & . I I & .17 & .17 & .30 & .55 & .80 & 1.05 & $1.3 \mathrm{I}$ & I. 56 \\
\hline$I_{4}$ & .12 & .18 & .18 & .32 & .59 & .86 & 1.13 & I.4I & 1.68 \\
\hline 15 & .12 & 19.19 & .19 & .34 & .63 & .92 & $1.2 \mathrm{I}$ & 1.51 & 1.80 \\
\hline 16 & .13 & .20 & .20 & .36 & .67 & .98 & 1.29 & $1.6 \mathrm{I}$ & 1.92 \\
\hline 17 & .13 & $.2 \mathrm{I}$ & $.2 \mathrm{I}$ & $.3^{8}$ & .71 & 1.04 & 1.37 & 1.71 & 2.04 \\
\hline 18 & .14 & .22 & .22 & .40 & .75 & I.10 & 1.45 & $1.8 \mathrm{I}$ & 2.16 \\
\hline 19 & .14 & .23 & .23 & .42 & .79 & I.16 & 1.53 & 1.91 & 2.28 \\
\hline 20 & .15 & .24 & .24 & .44 & .83 & 1.22 & $1.6 \mathrm{I}$ & 2.01 & 2.40 \\
\hline 21 & .15 & .25 & .25 & & & & & & \\
\hline 22 & .16 & .26 & .26 & & & & & & \\
\hline 23 & .16 & .27 & .27 & & & & & & \\
\hline 24 & .17 & .28 & .28 & & & & & & \\
\hline 25 & .17 & .29 & .29 & & & & & & \\
\hline 26 & .18 & .30 & .30 & & & & & & \\
\hline 27 & .18 & .31 & $\cdot 3 I$ & \multirow{23}{*}{\multicolumn{6}{|c|}{$\begin{array}{l}\text { ZONES-PARCEL POST GUIDE AND MAPS.-For parcel } \\
\text { post purposes the United States is divided into units of } \\
\text { area thirty minutes square. To ascertain in which zone } \\
\text { a post office is located from the office of mailing, a } \\
\text { parcel post guide, costing } 55 \text { cents, and map, costing } 20 \\
\text { cents, are jointly used. The guide applies to all offices, } \\
\text { but a separate map is required for each unit. A zone } \\
\text { key is furnished with the guide for use in the units of } \\
\text { area in which some of the largest post offices are located, } \\
\text { and makes the map for those units unnecessary. The } \\
\text { guide and maps may be pur hased by sending a money } \\
\text { order to the Third Assistant Postmaster General, Wash- } \\
\text { ington, D. C. Stamps are not accepted. }\end{array}$}} \\
\hline 28 & .19 & .32 & .32 & & & & & & \\
\hline 29 & .19 & .33 & .33 & & & & & & \\
\hline 30 & .20 & .34 & .34 & & & & & & \\
\hline 31 & .20 & .35 & .35 & & & & & & \\
\hline 32 & $.2 \mathrm{I}$ & $\cdot 36$ & $\cdot 36$ & & & & & & \\
\hline 33 & .21 & $\cdot 37$ & .37 & & & & & & \\
\hline 34 & .22 & $.3^{8}$ & $\begin{array}{r}.38 \\
.39\end{array}$ & & & & & & \\
\hline 35 & .22 & .39 & $\cdot 39$ & & & & & & \\
\hline 36 & .23 & .40 & .40 & & & & & & \\
\hline 37 & .23 & .41 & $\begin{array}{r}.41 \\
42\end{array}$ & & & & & & \\
\hline $\begin{array}{l}38 \\
39\end{array}$ & $\begin{array}{l}.24 \\
.24\end{array}$ & .42 & .42 & & & & & & \\
\hline $\begin{array}{l}39 \\
40\end{array}$ & $\begin{array}{l}.24 \\
.25\end{array}$ & $\begin{array}{r}.43 \\
.44\end{array}$ & $\begin{array}{l}.43 \\
.44\end{array}$ & & & & & & \\
\hline $4 \mathrm{I}$ & .25 & .45 & .45 & & & & & & \\
\hline 42 & .26 & .46 & .46 & & & & & & \\
\hline 43 & .26 & .47 & .47 & & & & & & \\
\hline 44 & .27 & .48 & .48 & & & & & & \\
\hline 45 & .27 & .49 & .49 & & & & & & \\
\hline 46 & .28 & .50 & .50 & & & & & & \\
\hline 47 & .28 & $.5 \mathrm{I}$ & $.5 \mathrm{I}$ & & & & & & \\
\hline 48 & .29 & .52 & .52 & & & & & & \\
\hline 49 & .29 & .53 & .53 & & & & & & \\
\hline 50 & .30 & .54 & .54 & & & & & & \\
\hline
\end{tabular}




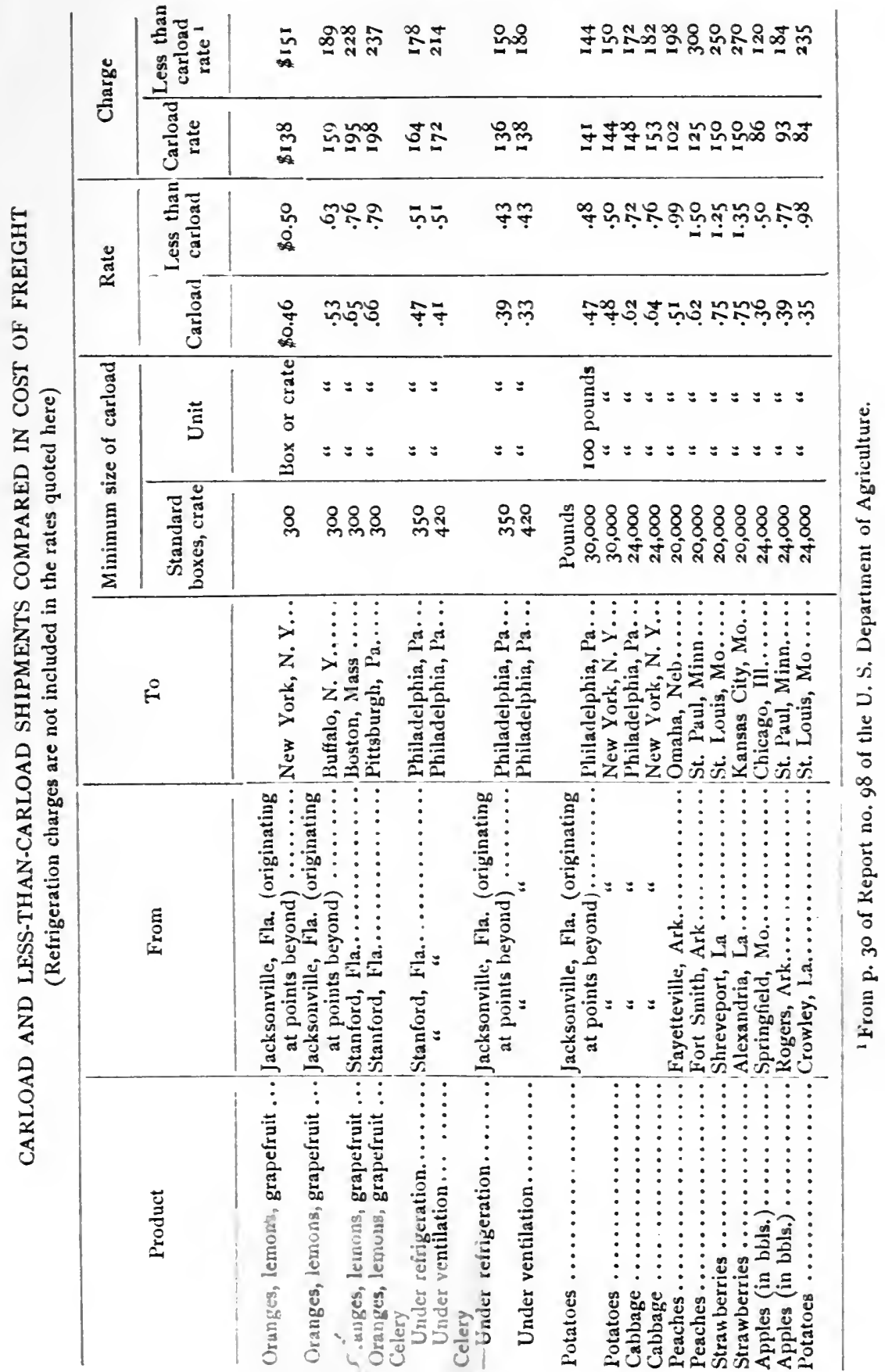




\section{CHAPTER III}

\section{Why the System is a Burden to Society}

IT was pointed out in Chapter I that the social costs connected with the marketing of perishables are to be found in the great fluctuation in prices, wide margins between prices in different sections, losses from decay of the goods, and the great average difference between what farmers receive per unit and what consumers pay per unit for the same products. The problem before us now is to determine why these factors are so large. In other words, we must locate the specific economic forces which will have to be dealt with in bringing about a constructive reform of marketing methods and practices.

I. REASONS FOR WIDE FLUCTUATIONS IN PRICES IN EACH

\section{MARKET}

The same fundamental economic forces govern the prices of perishables that govern the prices of all other commodities. So, in order to understand fully the extraordinarily great changes in the prices of perishables in a particular market it is first necessary for us to get clearly in mind the fundamental forces which control the prices of any commodity or all commodities.

\section{A. The Fundamental Economic Forces Which Regulate}

\section{Prices}

The price of a commodity in a particular market is controlled by two great forces. One of these forces originates on the side of supply, the other on that of demand. On the supply side the price-controlling force is the physical 
supply offered the market within the period considered. On the demand side it is the market schedule of demand prices. $^{1}$ A change in either of these iorces will affect the

1 At any one time each buyer has a schedule of demand prices for each good desired by him. E. g., A's schedule of demand prices for his week's supply of apples may be represented as follows: he would buy one-fourth of a dozen if he had to give 20 cents per dozen; threefourths of a dozen at $I_{5}$ cents per dozen; two dozen at ro cents; three dozen at 6 cents; four dozen at 5 cents; and not more than four dozen no matter how much lower the price might go. No matter what the price of apples may be, this is his purchase schedule for them, and he will not change his schedule because of a change in the price-though a change in the price will cause him to purchase a greater or a smaller amount according to this relatively fixed Schedule of Demand Prices. So an individual's Schedule of Demand Prices for a particular good is the number of its units he would buy in a given length of time (a week, a month, or a year) at different prices per unit. It is not the price he would pay for an additional unit of the good at a particular time; it is the average number of units of the good he would buy during each successive unit of time at each price in a scale of prices; it is the size of the continuous stream he is willing to take at different prices.

The number of units of a commodity which a buyer actually takes in a given length of time at a particular price shows exactly what his demand is at that price, but it does not show what his demand would be at any other price. What the demand would be at other prices is seldom consciously present in his own mind, but it may be approximately estimated from a knowledge of his habits and customs. A dormant, or potential, demand at a particular price becomes actively conscious, or effective, only when the market price changes to coincide with that particular price. It is conceivable that by a systematic shifting of the price of an article through a scale of prices a buyer's whole schedule of demand prices for that article could be secured by recording the amount which he bought in a given length of time at each price. But, as we shall see, a buyer's schedule of demand prices for each article constantly undergoes changes, so the record of past demands at different prices will not necessarily give the present schedule of demand prices for it. So, even though an individual's schedule of demand prices for an article were a very definite factor in every detail, it could not be quantitatively measured with absolute accuracy, because it exists as a potential force.

If the sums of the amount of the good which each buyer will take 
price, and, as we shall attempt to point out, they are the only forces which regulate the price. But before discussing how the physical supply offered the market and the market schedule of demand prices for a commodity regulate its price, let us first see how they themselves may be affected.

The physical supply of a good offered a market at a particular time may be changed by one of several factors, the principal ones of which are: the relation of the prevailing price per unit to the cost of production per unit; the nature and the character of the good; seasonal variation in production; and abundance or lack of information in regard to other markets. If the price is such as to offer producers great profits they will be tempted to increase their production for the market and thus increase the physical supply, or if the price offers no profit on production many of them will decrease their output and thus decrease the physical supply offered. Again, it may be that the peculiar character of the goods (perishable or subject to style changes) is such that the sellers are not able to hold a part of the physical quantity of the goods off the market even though the price does not suit them, so that the physical supply offered the market always varies directly with the production of the good. Seasonal variation in production (even though the goods are not subject to deterioration) may have a great deal to do with a change in the physical supply offered the market. During the season when production is

at a definite price could be obtained, it would give the market demand at that price, and so, by going through the whole scale of prices and adding the quantities all buyers will take at each, we would get the Market Schedule of Demand Prices for that market. Though the demand of each buyer at each price is a definite factor, the sum of their demands cannot be definitely stated because, as we have shown, the demand of each buyer at each price exists only within the buyers. Even though the market schedule of demand prices cannot be measured accurately, it is at any one time a definite force. 
heaviest a larger physical supply will be thrown on the market because many producers will not want to "hold", or can not hold the goods (for financial reasons). As the physical output becomes smaller the amount offered the market will also become smaller. Lack of information concerning prices in other markets, or, perhaps, the gaining of such information will sometimes cause sellers in a particular market to change the physical supply they are offering to that market; for if they find they can get more by transferring some of their goods to those other markets they will do so.

As a market's schedule of demand prices is dependent upon the schedule of demand prices of the individual buyers in the market anything which affects the individual buyer's schedule will affect the market schedule. The individual's schedule of demand prices for a particular commodity may be changed by any of the following factors: a change in money income; a change in the prices of other goods bought; or changes in customs and habits which affect his desire for the goods.

When a decrease in the money income of an individual occurs (granting that the prices of the goods he is buying remain the same) it will become necessary for him to buy fewer units of all goods, or a very much smaller number of units of one or more particular goods. If the particular good we have in mind is less of a necessity to him than any of the other goods which he is buying at that time he will greatly decrease his demand prices for that good ${ }^{1}-$ in short, he will buy a smaller quantity at the prevailing price. If this same thing happens to a great number of buyers the total amount of that product which will be sold

1 Because a smaller physical supply of it would not increase his marginal utility for additional units of it as much as his marginal utility for other goods would be increased by a smaller supply of them. 
at the prevailing price will be greatly reduced; in other words, the market schedule of demand prices will be reduced. On the other hand, an increase in the buyers' money income will have the opposite effect on the demand prices for this good.

Granting that the price of $A$, the particular commodity which we have in mind, remains the same, a change in the prices of other goods $(B, C$, and $D)$ taken by buyers will affect their demand prices for $A$. An increase in the prices of $B, C$, or $D$ (if they are necessities) will cause the buyer to spend a greater proportion of his money for them and leave less to spend for $A$ (if it is a luxury). Thus, his demand prices for $A$ are decreased. On the other hand, an increase in the prices of $B, C$, or $D$ (if they are luxuries) may cause the individual to spend less of his income for them and consequently have more to spend for $A$-which is another way of saying that his demand prices for $A$ rise. What is true of one buyer will probably be true of several buyers, so that a change in the prices of other commodities will affect the market schedule of demand prices for the particular good we have in mind-though a change in its own price will not affect the market schedule of demand prices for it.

A change in the habits and customs of an individual which affects his desire for a particular commodity will alter his schedule of demand prices for that commodity. If for social or psychological reasons he increases his desire for a certain number of units of the commodity in a given length of time he will consequently raise his demand prices for it. If his habits and desires change so that he decreases his want for it he accordingly decreases his demand prices. Any change in the fashions will illustrate this point.

No matter what factor brings about a change in the market schedule of demand prices for a good in a particu- 
lar market, the change will affect the price of that commodity. If this schedule rises, the price will likewise go up (granting that there is not a corresponding increase in the physical supply offered the market). This will be true because the amount of the good that buyers would take at the then prevailing price with their higher schedules of demand prices will more than equal the physical supply offered. As the physical supply begins to be reduced sellers will realize that buyers have increased their schedules of demand prices for the good, and they will accordingly raise the price. The theoretical limit to the rise would be the point in the market schedule of demand prices that would equal the physical supply offered, but the price may actually go higher than this, because sellers may put it high enough to prevent a complete exhaustion of the physical stock on hand. A fall in the market schedule of demand prices for the good would lower its price, because then buyers would not take as large a proportion of the physical supply as formerly. In order to get rid of their surplus goods competition between sellers would tend to make them lower their price-offers.

An increase in the physical supply offered the market will tend to reduce the price of the good; buyers are already taking as large quantities as their demands, at the prevailing price, will permit; a surplus will accumulate on the market, and, in order to get rid of, or reduce, this surplus, competition between sellers will again cause them to lower their price. The limit to the reduction in the price is controlled by two factors. First, the price will never go lower than the point where the demand price of the market will take the total physical supply available to the market-we have seen that it would seldom, if ever, reach that point. There is another important factor, called sellers' rescrvation prices, which tends to uphold falling prices. The seller's 
reservation price is the price at which he will refuse to put his goods on the market. The point at which sellers will fix their reservation prices will depend upon the character of the good (whether or not it deteriorates from being held off the market), the financial strength of the sellers (ability to hold), the cost of storage, and the sellers' estimation of the trend of future prices. So the reservation prices of some goods are necessarily very low and of others very high. In the case of low reservation prices, an increase in available physical supply will tend to reduce the price to the point where the market-demand price equals the physical supply available. But if the available physical supply happens to be greater than the maximum amount which will be taken by the market at the lowest prices (according to the market schedule of demand prices) there will be no limit to the fall in the price-this is called a "glut".

A reduction in the physical supply will have the opposite effect on the price-that is, will tend to raise it. Buyers will want to get the same stream of goods at the prevailing price and many of them will succeed in doing so at first. This will further decrease the physical supply available to the other buyers, who also want their accustomed stream of goods at the prevailing price. The sellers, perceiving this shortage of physical supply in relation to the demand prices of buyers, will raise the price per unit. We have already discussed the theoretical limit to the rise in the price in case of a discrepancy between the physical supply and the demand prices of buyers.

So the price of an article in a particular market constantly tends toward a point in the market schedule of demand at which the amount bought equals the total physical supply available for the market. Any change in the market schedule of demand prices for the article, or any change in 
the physical supply offered the market will influence the price. Unless one or the other of these factors does change there will be no fluctuation in the price.

\section{B. How These Forces Regulate the Prices of Perishables}

That the physical supply of perishables thrown on each market varies greatly from season to season is too well known to require much discussion. Table II ${ }^{1}$ shows that the New York wholesale market received a greater total quantity of eggs in the four months of March, April, May and June of I9I4 than in all the other eight months of the year. The receipts of butter in the summer months of June, July and August were nearly as great as the total receipts for the remainder of the twelve months. If it were possible to get the figures for fruits and vegetables they would show that the receipts for the summer months are even greater proportionately than for butter and eggs. The seasonal variation in the receipts of perishables in the New York market, as shown above, is very great; the variation in the receipts of smaller towns and cities is relatively much larger than for New York, because New York gets perishables from a much wider market than do the smaller cities.

If we study the changes in the physical supply received by any wholesale market from day to day or from week to week, we find that they are far greater than are the seasonal changes. It is not uncommon for the receipts on one day of a particular perishable in the New York market to be ten times larger than they were the preceding day. ${ }^{2}$ And it often happens that two or three times as much fruit or vegetables will be received one week as in the preceding or

${ }^{1}$ Cf. supra, p. 36.

2 See the current issues of the New York Price-Current Sheet. 
succeeding weeks. Again, this short-time fluctuation in physical supply in New York City is not as great relatively as it is for the smaller cities because the former receives a large enough quantity for the law of averages to make it more constant.

The seasonal changes in the physical supply received by each market are due largely to the following causes: (a) the seasonal production of the goods; (b) their natural perishableness.

(a) As matters stand to-day, the harvesting (or production) of each perishable either lasts only a part of the year or is much greater in some months than in others. Of course, the harvesting season for fruits and vegetables in any one section lasts only a few months-for strawberries the season is measured by weeks, but for peaches and beans it is longer. Because of our large area in the United States, the harvesting season for each widely-grown product is very much longer for the country as a whole than for any one particular section, so there is a new supply of some products for the general market over quite a long period of time-the potato harvest illustrates this point. But, notwithstanding the wide area over which many perishables are now produced, a far larger proportion of them is harvested from May to October than in the winter months. This is true of dairy and poultry products as well as of fruits and vegetables.

(b) Because they are subject to rapid decay, perishables are sent to the primary and wholesale markets as soon as possible after they are harvested. And, for the same reason, these markets generally offer them as quickly to the retail markets. Wheat, cotton and other staples are ordinarily sold by farmers pretty soon after they are produced, just as perishables are-but because staples do not deteriorate from one harvesting season to another the men who 
buy them from farmers (middlemen) do not immediately offer the total supply to the market, but hold a large part of it in reserve, anticipating a shorter future supply and higher prices. The risk of holding perishables for a considerable length of time is too great for middlemen, so they offer whatever supply of the goods they may have at any time at the prevailing price. Consequently, the physical supply of perishables offered the primary, wholesale and retail markets varies according to the harvesting season.

The short-time (daily and weekly) variations in the physical supply offered different markets is primarily due to the lack of accurate market information on the part of sellers. In the busy shipping seasons we often have the situation where one wholesale market will be getting extraordinarily large shipments of certain fruits or vegetables while at the same time other wholesale markets, just as close to the shippers, will be receiving an exceedingly small quantity of the same kind -of fruits and vegetables. This is due to the fact that shippers who are sending to the glutted market have little or no information in regard to the quantities of goods which are being shipped to either of these markets. In other words, there is no market information for this class of goods as there is for staples. Whatever information shippers get as to daily receipts, prices, etc., in the different markets is not only very inaccurate, but exceedingly costly as well. So most perishables are shipped to wholesale markets on faith or by guess.

When buying in wholesale markets the retailer's demand prices are regulated by his estimation of the demand prices of his customers. The wholesaler's demand prices are in turn determined by his estimation of the demand-price schedules of retailers. In other words, the schedule of demand prices of each middleman is determined by his estimate of the demand prices of those to whom he expects to 
sell the goods, and, in the last analysis, all demand-price schedules are based on those of the consumers.

Consumers' schedules of demand prices for perishables are relatively stable because the goods are food necessities and as such are the last goods to be affected by a change in the money income of consumers. For the same reason, a change in the prices of other goods will have little weight in influencing the consumers' demand prices for perishables, and a change in the habits of consumers is not likely to affect their demand prices for these goods. Therefore, consumers' schedules of demand prices for perishables as a class change very little.

But because of the opportunity for substitution between different commodities in this class of goods, a change in the price of one is very likely to upset the old schedule of demand prices for another. For example, if the price of oranges goes down the consumer may decide to buy a larger quantity of oranges instead of grapefruit (which remain at the same price). If cabbage goes up in price and beans do not, he may decide to buy a much larger quantity of beans to take the place of cabbage. On the other hand, if peaches go down in price the consumer may buy a much larger quantity of them and a smaller quantity of oranges which remain at the same price. The range of substitution between the various perishables is very great; but this factor may easily be overestimated as a disturber of the consumer's schedule of demand prices for the commodities as a class. Even the substitution between the different products in the class is limited by the desire for variety of flavors.

It is, then, changes in the physical supply available for the market and not changes in the market schedule of demand prices which is the primary cause of the great fluctuations in the prices of perishables. But why are the fluc- 
tuations so great and violent as they are? Of course, the principal reason is that sellers cannot have very definite reservation prices for these goods. When the physical supply in a market increases, sellers reduce their prices in order to get rid of the surplus goods on their hands. They cannot hold these goods off the market because the price does not suit them, but must continue to offer them at lower and lower prices until the price reaches the point in the market schedule of demand prices when the current purchases about equal the physical supply.

The character of consumers' schedules of demand prices for this class of goods must be taken into consideration in order to understand fully the cause of the extreme fluctuations. With perishables there is relatively little difference between the quantity (number of units of the goods) which will be taken at high or low prices per unit. For example, if cabbage are selling at $9 c$ per pound a consumer may take seven pounds per week; and at $6 \mathrm{c}$ he will take eight pounds; at $4 \mathrm{c}$ he might buy nine pounds, but he would hardly buy more than this even at $1 / 2 \mathrm{c}$ per pound. In other words, after a certain low price is reached consumers will buy enough of the good to satisfy all their desire for it and will want no more at any price. This, of course, is due to the fact that the satisfaction of the appetite is a prime necessity and after the amount needed fully to satisfy it is secured additional units of the good have no value. And, because the satisfaction of the appetite is a primary want, the consumer will buy nearly enough goods to satisfy it fully even at very high prices. ${ }^{1}$

1 When prices of perishables are low some urban housewives buy more than their families can immediately consume, and use this surplus for canning and preserving. This practice, of course, tends to increase the quantities purchased at low prices, but domestic canning and preserving is not carried on to a very great extent by city families, and is therefore a limited factor in increasing the physical quantities which would be purchased in the market at lower prices. 
That retailers recognize this peculiarity of consumers' schedules of demand prices for perishables is shown by the fact that they rarely reduce their prices below the point where consumers will buy the maximum quantities no matter how low the price might be in the wholesale market. On the other hand, because of the idea of " just prices" in the minds of consumers, retailers are restrained from raising their prices very much even when wholesale prices are highest. Rather than raise their prices to very high points and so get the ill-will of their consumers they often sell below prevailing wholesale prices or refuse altogether to handle the perishables. So, for these reasons, we have slight changes in retail prices as compared with the relatively very great changes in wholesale prices.

The customs and practices of retailers intensify the price fluctuations in the wholesale markets. When the physical quantity in the wholesale market increases, wholesale dealers reduce their prices to get rid of the surplus. But this induces retailers to increase the physical quantity of their purchases very little (because they can only slightly increase the physical quantity of their sales by lower price-offers). The wholesalers cannot have a reserve price; so they must make further reductions. Still the surplus is not taken by retailers; so the wholesale prices go down until much of the produce cannot be sold at any price. On the other hand, when the physical quantity in the wholesale market becomes very small, prices jump to a very high point because retailers will continue to buy about the same physical quantity at higher and higher prices as long as there is a margin between the wholesale prices and the maximum prices they will charge consumers. Of course, the prices that shippers and farmers will receive fluctuate in direct ratio with the changes in wholesale prices. 
II. SECTIONAL MARGINS IN PRICES: CAUSES

The fact that the farm price of tomatoes in Delaware was $29 \mathrm{c}$ per bushel and in Georgia \$1.25 per bushel on the same day ${ }^{1}$ may have been due to either or both of two factors: The Georgia growers or shippers may have been able to find a market (or markets) which the Delaware growers or shippers were unable to find. Or, because of peculiar circumstances, the cost of getting the Georgia tomatoes from farmers to the consumers may have been much less than the cost of marketing the Delaware tomatoes.

(a) In our discussion of price fluctuations we saw that, because of the lack of market information, it often happens that many sellers do not ship to markets which are in great need of the goods they have to sell, but instead ship to other markets which do not demand their goods. This lack of market information is so complete that sometimes all the shippers of a particular product in a whole state fail to find the best markets, but send to glutted ones instead. It is certain that much of the sectional differences in prices of particular products at any time is due to this fact, and it is very likely that it was a large factor in accounting for the difference between the prices of tomatoes in Georgia and Delaware. In so far as sectional differences in prices are due to lack of market information they are a part of the phenomena of short-time price fluctuations.

(b) There is no doubt that this margin between the farmprice of tomatoes in the two states referred to above existed partly because the products of Georgia growers could be marketed more cheaply than could those of the Delaware growers. Very likely the Georgia tomatoes, on the average, were marketed more directly than those of Delawarethey passed through the hands of a fewer number of mid-

1 See table iv, p. 39. 
dlemen and so there was less difference between what the producers received and what the consumers paid for them.

The above conclusions are based on the following facts: In October, at the time these prices prevailed, the tomato season in Georgia was practically over. The greater part of the crop had been harvested in August and September, whereas, in October the harvesting of this crop in Delaware was in full swing. There was, at that time, a much greater local physical supply in Delaware than was demanded by the local consumers, but the local physical supply in Georgia was far below the local demand. In order to get rid of the great surplus a large part of the Delaware tomatoes had to be shipped to distant markets, while there was a strong local demand for the few Georgia tomatoes. Georgia being a state of many small towns, most of the growers who had tomatoes to sell disposed of them either directly to the local consumers or to the retailers. Under such circumstances, the Georgia growers did not count the expense of finding a market for their goods as "cost of marketing" (though the work may have been very expensive), but counted the total receipts as "farm-price." On the other hand the Delaware growers were selling largely to country shippers who sent the produce to different wholesale markets to be distributed by the usual middleman methods. ${ }^{1}$ Owing to the expense of passing goods through such a complicated system and to the great deterioration of the goods before they reach the individual consumers, there was a great

${ }^{1}$ Because of the shortage of the local supply of tomatoes in Georgia there is little doubt that Delaware tomatoes were, to some extent, shipped to Georgia through the middleman system and sold to Georgia consumers at the same prices they were paying nearby farmers for local tomatoes. In this case, the difference between what the Georgia farmer received for tomatoes and what the Delaware farmer received exactly equaled the cost of getting Delaware tomatoes to Georgia consumers through the marketing system. 
difference between the prices consumers paid for Delaware tomatoes and the prices received for them by growers.

An examination of the sectional differences of farm prices of every perishable farm product will show, as in the case of tomatoes, that the price will be comparatively high when the amount being harvested will supply only a small proportion of the local consumption and comparatively low where the local harvest exceeds the local demand for inmediate consumption. We find, then, that generally the farm prices of all perishables in each producing section are lowest during the period of greatest harvest, and highest during the season of smallest harvest ${ }^{1}$ the low prices being due to the cost of disposing of a surplus to distant consumers, and the high prices to the cost of supplying a deficit to local consumers. As the harvesting seasons are not the same for different producing sections there is always a considerable margin between the prices in different localities. The wholesale and, to some extent, the retail prices for each perishable in the consuming centers move up and down directly with the farm prices of the nearby farms. Sectional price differences, then, can be lessened considerably by getting goods from farmers to distant consumers.

\section{CAUSES OF LOSSES FROM DETERIORATION}

We have seen that deterioration is one of the fundamental causes of fluctuations in the physical supply offered different markets. It is hardly necessary to state that the primary reason for the losses from decay of from thirty-five to forty per cent of perishables raised for the market is the natural perishability of the goods. For this reason the name "perishables" was chosen for this class of goods. But,

${ }^{1}$ This is not always true of farm prices near very large cities where the local supply only constitutes a fraction of the local demand and where farmers rarely sell directly to consumers at any season. 
aside from the inherent characteristics of the goods, there are two further reasons why these losses are so great under the present system of marketing. The first reason is the comparatively long time it takes to get goods from producers to consumers (time means deterioration with perishables); and the second, the poor care which is given the goods from the time they are produced until they can be put in the hands of consumers.

I. The average length of time it takes perishables to pass through the marketing system is prolonged by three factors : (a) seasonal production of the goods; (b) the average great physical distance between producers and consumers; and (c) inability of the marketing system to distribute the available goods to the markets where they are most in demand.

(a) As has been pointed out, the bulk of perishables in the United States as a whole is harvested in the summer months, while the demand for them is fairly constant throughout the year. The physical surplus of one season must be kept in reserve for some time if it is to be consumed at all. This, of course, prolongs the average time between production and consumption. The only way this time can be shortened is by making the harvesting season more constant for the country as a whole-a problem which we shall discuss in another chapter.

(b) The fact has been mentioned that, on the average, the consumers of New York City receive their perishables from producing districts more than I,O00 miles away, or a distance of more than four days of fast freight, and that the goods consumed by other large cities come from sections very little closer. ${ }^{1}$ Though our transportation facilities are unsurpassed by those of other countries, and though we are constantly accelerating the speed at which all goods move,

\section{Page I5.}


the physical distances perishables have to travel bring in a considerable time element. Because of this distance between producer and consumer the present complicated marketing system has been built up. The extreme complexity of the machinery prevents the rapid passage of goods "from farm to family." There is only one way completely to eliminate losses from this cause, and that is to limit the area of the market so that each section of the country must produce all the goods that it consumes.

(c) The fact that at the same time one market will be glutted with certain perishables and another will be experiencing a great scarcity of the same products shows that the general available physical supply is not distributed so as to equalize demand in the different markets. Such a condition causes many products to stay in the glutted markets until they decay, whereas, if they had been sent to the other markets they would have been consumed. Again, it often happens that farmers in certain sections will be compelled to let their goods rot on their hands because they can not find a market, while consumers will be paying very high prices in not far-distant markets for the same goods because there is not an adequate supply. Such prolonging of the time between production and consumption is due largely to the lack of reliable market information.

2. Many perishables decay because they do not receive the proper care before and after they enter the market. They are unduly exposed to heat and cold, to moist and dry winds, and decay much more rapidly than they would under proper temperature and atmospheric conditions. They are not properly graded; the storage and refrigeration given them is inadequate; and they are moved from place to place under unfavorable conditions. These facts can be brought out more clearly by a description of the way perishables are handled before they reach the consumer. 
As a rule, farmers take few precautions to protect their perishables from decay. In harvesting they unduly expose the produce to unfavorable weather conditions. In . many cases they allow their fruits and vegetables to remain in the fields several days after they are ready for harvesting. The result is that when they are harvested much has fallen to the ground and is greatly damaged by wind, rain, and sun or by birds and insects. So when they are brought from the fields, a large proportion is already unfit for human consumption. As was shown by the quotation on page 35 , eggs receive little more care in gathering than do fruits and vegetables. After the crops are gathered farmers provide few facilities for properly caring for them until they are hauled to the market. The butter is not put on ice, eggs are left in hot pantries, fruits and vegetables are not placed away from germs and insects in storage houses of cool and even temperature. In many cases they do not even separate the decayed produce from the sound, but allow the rot to infect the whole. After subjecting the produce to such treatment for several days, the ordinary farmer hauls it to market in an open wagon where it is exposed to the natural elements for several hours. So there is little wonder that much of the produce arrives at the primary markets in a very unsound condition.

It is not possible to say just what percentage of decay occurs while the goods are in the hands of country shippers, but it is known to be considerable. Of course, one of the reasons for decay here is the treatment the goods have received previously at the hands of the farmers. But inadequate facilities and lack of expert training on the part of many shippers are other reasons for decay. Some of these men possess insufficient capital to provide proper storage and refrigeration, and the scale of business of others is too small to justify adequate expenditures for these facilities. 
Again, many shippers have gone into the business with little or no knowledge of how to take care of the goods; in some cases, as country store-keepers, they have been forced to take up this work in order to hold the trade of the surrounding farmers; in other instances, they have gone into the business because, considering their capital and training, it looked more attractive to them than any other. So the result is that often while the goods are waiting at the shipping point to be sent to the wholesale market they are neither cared for by proper storage, pre-cooling, or refrigeration, nor are they graded and packed properly, but are started on their way to market in a wretched condition.

In discussing transportation we saw that there were two reasons why goods deteriorate greatly while in the hands of transportation companies. First, the methods by which they are shipped: The small shipments (by parcel-post, express or freight) heretofore have received little protection from heat or cold and consequently have a high percentage of decay. Many car-lot shipments perish on the road from being sent without ventilation or refrigeration (either because the sender could not get better facilities or because he was not willing to pay for them). The second contributing factor is undue delay while en route: slow travel and traffic tie-ups through some fault of the transporting companies cause no small amount of losses.

The improper handling of perishables at wholesale centers consists of inadequate terminal facilities, excessive and careless cartage over the cities, and faulty re-grading and re-packing. There are few American cities which have adequate terminal facilities for perishable produce. Each railroad and steamboat company has its separate freight terminal, instead of there being one large terminal for all. There are few, if any, facilities connected with these many terminals for loading and unloading perishables. Instead 
of being run into a large storage house or shed provided with refrigeration, the cars or boats are unloaded, in the open, onto trucks which carry the produce through the streets to public or private warehouses, sometimes quite distant. When traffic at these terminals is congested the trucks have to stand for several hours with their produce in the open. The goods are thus subjected to all kinds of temperature and weather; they may be taken from an ice-cold car and allowed to lie on an open truck in the broiling sun for several hours, or they may be taken from a fairly warm car out into freezing weather. Naturally, such exposure causes very decided deterioration in the produce.

It often happens that, as produce changes from the hands of one wholesale dealer to another, it is carted several times from various public or private warehouses to others across the city,-each haul further exposing the produce to decay. Many wholesale dealers do not have their own storage and refrigeration facilities, but depend on the public warehouse companies for them. Owing to the general inadequacy of public warehouse service, much of the goods cannot be placed in proper storage at all when there is a slight surplus of the goods in the market.

A further loss is brought about by improper re-grading of the goods by the wholesale dealers. If that part which is sound is not quickly and thoroughly separated from the decayed produce on arrival the decay will spread. Because they feel that they can sell the decayed produce to some one else, some dealers do not thoroughly re-grade and re-pack the goods when received.

Perishables are often further ill-treated after they reach retailers. They are placed in hot store-rooms or on the open streets; roughly handled by prospective customers; and exposed and bruised while being delivered to the customers. 
IV. CAUSES FOR WIDE MARGINS BETWEEN FARM-PRICES AND CONSUMERS' PRICES

The main reasons why the average margin between what farmers receive for perishables per unit and the prices consumers pay for them per unit is so wide are: (a) losses from decay; (b) fluctuations in prices; (c) the heavy expense per unit for goods passing through the marketing process; and (d) inefficient methods and dishonest business practices of middlemen.

(a) From 30 to 40 per cent of the margin between farm prices and retail prices of the goods which pass through the middleman system is due to the great losses from decaythat is, this percentage of the margin goes to pay for goods which are bought from farmers but never reach consumers. Some one must stand the loss, so it is added to the price of the goods which do not decay. Any improvement in the products or in methods of preventing decay will greatly lessen the margin between producers' and consumers' prices.

(b) The uncertainty of the price which each middleman will receive causes each when buying goods to allow a large enough margin between the price he pays and the one he expects to receive to insure him against this uncertainty. That is, he will not buy the goods unless he can get them at a low enough price to make him safe, even if the price at which he will be able to sell is far below what he expects. This insurance charge will be reduced in proportion to the reduction in price fluctuations.

(c) In Chapter II we gave a detailed analysis of the actual expenses of those middlemen who handle perishables. We saw that the average expense per unit for handling these goods was not very great for any except the retailers, but, owing to the fact that the products pass through the hands of several different middlemen on their way to consumers, 
the total expense per unit is considerable. We have often been told that the reason for the great total expense of carrying a perishable through the marketing process is that the system of marketing is too complicated and that there are too many middlemen. In some cases an excessive number of middlemen does, in fact, add to the expense of getting the goods to consumers, but this is not the main reason. ${ }^{1}$ Whether the goods pass through the hands of a-dozen middlemen or only one there are three important economic reasons why the expense of getting them from producers to consumers is necessarily high under the present breadth of the market. They are : first, the great average distance between the producers of these products and the consumers; second, the fact that they are produced by a small business unit (the farm) and consumed by a smaller business unit (the family); and third, the relatively high expense of caring for the goods.

The greater the distance between the producer and the consumer of any article, the greater the cost of getting the article from one to the other. The expenses of salesmanship are necessarily much heavier when great distances must be covered to find buyers. The preparation for shipment, the cost of transportation, and the expenses of making collections are likewise much greater under such circumstances. As the market for perishables has recently widened from a local market to a national one, the necessary expenses which go with a wide market must be borne or the breadth of the market lessened.

In discussing the reasons for the high expense of getting perishables from producers to consumers the fact is ordinarily overlooked that these goods must either be handled

1 We shall discuss the possibilities of simplifying the marketing processes and eliminating middlemen in the next two chapters. 
in very small packages ${ }^{1}$ by one market man or several times by many middlemen. Even the large individual grower rarely sells more than two or three car lots of a particular perishable in a whole season-and each separate sale is much less. The average family seldom buys more than three or four pounds of a particular perishable at a time. So for one man (the producer) to get a given quantity of perishables to consumers (granting that the market can be found easily) it is necessary to grade, pack and ship the goods in very small packages. If the goods are marketed by several middlemen through a "system" they must be gathered in comparatively small quantities from producers, made into large shipments, and then broken up into small packages for distribution to consumers. This requires, as we have seen in our study of the work of the middlemen, a good deal of expense-particularly is this true at the retail end where the goods are broken up into very small lots. The expense per unit of getting iron ore from producer to consumers is not so large because it is produced by large business units (the mines) and sold to large business units (the mills) - it is never broken up into small lots.

The expense of taking care of perishables while they are being marketed is great, for they must have storage and refrigeration and must be carefully graded by hand and packed in small packages. As it is to-day, not enough care is given these goods and the expense is not as great as it would otherwise be, but nevertheless, the cost of getting perishables from producers to consumers is much heavier than for goods which do not require such tender care and handling. If pig iron were produced by farmers and con-

1 Packages which contain the quantity of perishables which are ordinarily purchased at one time by the average family. 
sumed by families and marketed by the same marketing machinery as are perishables, the expense of passing it through the system would be much less because there would be little or no charge for taking care of it.

(d) Because of the ignorance of many shippers as to the best methods of grading and packing, their goods have to be re-graded and re-packed by the wholesalers. The absolute lack of uniformity in grades and packages causes untold work in the wholesale centers in reducing the goods to uniformity in grades and packages. The failure of many shippers to follow recognized business methods in finding a market for their goods is another factor which adds to the expense of moving the goods. The amount of business carried on by many shippers and wholesalers is so small that their cost of doing business is very large, per unit of goods handled. Of course, it has long been recognized that the average corner grocer, who retails the bulk of the perishables in the United States, has a far too high cost of doing business, owing to his lack of business methods and the small size of his business unit. There is little doubt that if each middleman had a thorough knowledge of how best to run his business, or if efficient business men were substituted for those of the middlemen who are incompetent, the total expense of the whole middleman machinery would be greatly reduced.

The deliberately dishonest business practices of many middlemen swell their receipts and add to the margin between producers' and consumers' prices. There is little government regulation or inspection of the business practices of middlemen engaged in marketing perishables. Some country shippers get a monopoly of the shipping business in their section and pay the farmers ruinously low prices for produce in order to swell their own profits. Commission men charge commissions varying from two to twenty-five per 
cent. They often return to shippers " account of sales" at far below the figure they actually received for the goods, and "pocket" the difference. And occasionally they report sales (at low figures) before they have actually sold the goods-expecting to receive higher prices for them. It is possible for wholesale men willingly to give out inaccurate price quotations to induce shippers to send to their market, that they themselves might buy at very low prices. Because shippers are not represented in the wholesale markets, those who inspect and buy their goods often give false reports in regard to the extent of decay of the shipments in order to get the goods at prices below their market values. Other forms of price manipulations and "corners" have been occasionally practised in the wholesale markets. ${ }^{1}$ It is not possible to say just how much effect these different dishonest practices on the part of wholesale men have in adding to the margin between producers' and consumers' prices, though it is certain that they are, in particular instances, of exceedingly great importance.

v. SUMMARY OF FACTORS TO BE DEALT WITH IN REDUCING

THE SOCIAL COSTS OF MARKETING PERISHABLES

The social burdens incident to the marketing of perishables are due to two main causes : First, to the inherent characteristics of the goods themselves; Second, to the imperfections in the methods and processes by which they are marketed.

Because of the natural perishability of the goods, many of them become unfit for consumption before they can be offered to consumers. The natural seasonal production of

${ }_{1}^{1}$ These are accusations which are commonly brought against all middlemen who deal in perishables. Certainly, under the present system their opportunities to engage in "sharp practices" without being "caught" are very great. 
the goods creates temporary surpluses in the available physical supply which adds greatly to the decay of the goods by lengthening the average time between their harvest and consumption. The burden of marketing them is further increased because they are goods which must be produced by a small business unit (the farm) and consumed by a smaller one (the family). No matter what marketing system or marketing processes or practices might be used, these natural characteristics of the goods would make the marketing of them expensive and burdensome.

After taking into consideration the natural characteristics of the goods we have found the following main defects in the marketing methods and processes: very poor care is given the commodities before and after they enter the market; market information which is available is so inadequate and the cost of assembling it so great that those who are engaged in marketing the goods are unable to adjust, in the general market, immediate physical supply and actual demand; the complicated marketing machinery seems to be too expensively run, either because it is too complicated or because the operators are not efficient; and the middlemen (or operators) are not always honest and fair in their dealings.

The last chapter (Chapter VI) of this book will be taken up with a brief discussion of the possibilities of changing the natural characteristics of perishables. But the principal question with which we are concerned in this study is: How can the marketing methods and processes be reformed, or the marketing system changed so that the costs of marketing the goods will be reduced? Let us now turn to this task. In pursuing it we shall assume that the nature of the goods is in every way unchangeable. 


\section{CHAPTER IV}

Reform of thp Marketing Processes or Machinery

I. SUGGESTED PROGRAMS OF REFORM

No question has aroused a more widespread discussion than that of the economic value and functions of the whole middleman system, through which perishables are now almost exclusively marketed. It is clear from most of the discussion that there is no problem on which there is wider diversity of opinion, or one which is more generally misunderstood. ${ }^{1}$

The critics of the middleman system may be divided into three classes: Those who would abolish the whole systemboth the middleman and the machinery; those who would retain the essential features of the machinery or methods of the system, but would abolish all private middlemen; those who would retain both the machinery and the private middlemen, but would reform the machinery in many respects, eliminate some private middlemen, add others (either private or coöperative) according to the circumstances, and regulate the practices of all middlemen of whatever character. ${ }^{2}$

The critics of the first class would institute direct marketing between all producers and consumers. They believe that the entire system is, at present, a burden to society;

1 "Not fully understood by any of us." Stillman, Annals of Amer. Acad. of Pol. and Soc. Sci., vol. lix, p. 65.

2 Classification made from general criticism of various writers. 465] 
that all middlemen are parasites who collect a heavy toll from both producers and consumers; that the machinery of the system is worse than useless; and that all perishables could be marketed more efficiently and cheaply by direct dealings between producers and consumers.

Those of the second class also see quite a useless complication in the whole marketing system, but they hold private middlemen responsible for most of its shortcomings. They would, therefore, eliminate all these and have the work they now perform carried on by coöperative associations with less machinery. Those who hold this view either believe that private middlemen, as a class, are irredeemably dishonest and inefficient, or that there is something inherently good in coöperative marketing associations which would make them far superior to private middlemen as marketing agents.

The third class of critics are more conservative. They see something good in both the complicated machinery of the system and in the private middlemen. They recognize that in many cases the methods or processes of marketing can be improved-that in some instances the processes are too complicated, while in others too simple, to be efficient. They do not hold the private middlemen directly responsible for all the defects that are found in the present system of marketing, but recognize that there are some dishonest men in the trade together with a great many others who do not efficiently do their work. Neither do they believe that there is anything inherently superior in coöperative marketing. They would advocate both coöperative marketing and municipal markets (and even direct marketing) in certain cases and under certain circumstances, while in other instances they would prefer to have the work performed by private middlemen. They advocate a program neither for the abolition of the present marketing machinery nor for the doing 
away with all private middlemen; but one for reform and regulation of the present system.

Each of these suggested programs aims to accomplish either one or both of two things: (I) the reduction of the costs of marketing perishables by the establishment of less complicated machinery or processes; (2) the reduction of the costs of marketing them by reducing the costs of performing the marketing processes-or of running the marketing machinery. Before accepting or rejecting any of the proposed programs let us see, first, under what conditions, and how, the marketing processes can be reformed; second, how the costs of performing the necessary marketing processes can be reduced. This chapter will be taken up with a discussion of the simplification of the marketing processes.

\section{LIMITATIONS OF DIRECT MARKETING}

Whether a particular good is marked through a "system" where the work of getting it to the consumer is divided between several men, or whether the total process is performed by only one man without the aid of a "system", the work itself consists (a) of finding a consumer who will buy the good, and (b) of delivering it to the consumer and receiving payment. We have already seen that if perishables are to be marketed efficiently they must be sold to consumers at reasonable, uniform prices pretty quickly after they are harvested, and the cost of performing the operation must be reasonable. Under present industrial conditions, how efficiently and cheaply can consumers be found for these goods by using direct marketing methods? What if any are the limitations of direct marketing?

\section{A. Finding Consumers}

There are three modern ways of finding buyers for 
goods: ${ }^{1}$ (I) The seller may display his goods before the eyes of the prospective buyers and thus induce them to take the goods-the ordinary retailer sells by this method. (2) Goods may be sold through samples either by the owner or by his agent-selling through "drummers" or solicitors is a good example of this method of finding buyers. (3) Goods may be sold through advertisement either in newspapers and magazines or in catalogues-the mail-order business illustrates this type of sale. Whichever method is used in finding buyers, the following conditions must be satisfied before the sale can be consummated: The seller must find an individual who is not only able, but desires, to buy the particular article he has to sell. The prospective buyer must know something of the quality and quantity of the good offered him, as well as at what price other sellers are offering the same grade of good. The seller also must know something of the competitive offerings in order to be able to set the price on his goods to his advantage.

By which of these methods of sale are the individual peach growers of Georgia or the poultry raisers of Oklahoma to sell their produce to individual consumers in St. Louis, Philadelphia, New York and other cities? How are the fruit and vegetable producers of California, Oregon, Louisiana and Texas to find individual consumers who will buy their goods in Washington, Pittsburgh, Atlanta and New Orleans? It is certain they cannot meet these city dwellers face to face and display their goods as does the local retailer-distance alone would prohibit the employment of such a method. The second practice of selling by sample through house-to-house canvassers or agents may be a little less expensive than the first method, but hardly more practical. The agent's commissions would about

${ }^{1}$ Shaw, A. W., Quart. Jour. of Econ., vol. xxvi, pp. 72I-75r. 
equal the total cost of marketing through the middleman system, to say nothing of the losses from lack of adequate market demand, decay of goods and cost of grading, packing and shipping. However, many believe that it is practicable for farmers to find a market with distant individual consumers through the third method-that of advertising. Doubtless this method is more feasible than either of the other two, but there are many drawbacks to its extensive application to perishables: (a) perishables are not generally bought by consumers until desired for immediate use; (b) the goods are not sufficiently standardized to be sold extensively by advertisement: (c) the expense of advertising would be too great; and, (d) customers could not be helil because of the seasonal supply of each farmer.

Individual families do not generally keep a large supply of food on hand. Few have storage room to do so if they desired, so practically all of them buy food from day to day according to their immediate desires or appetites. They buy perishables in smaller quantities because of rapid deterioration, and keep on hand a smaller supply of these than of any other class of food products. To "order" such goods from distant producers would necessitate buying at least several days ahead, and in larger quantities. In other words, they would have to estimate what their future appetites would desire, invest money for future consumption, and run greater risks of losses from decay. In order to induce them to go to this great trouble the price would certainly have to be much lower than it is under the present system.

To buy on the basis of an advertisement or a catalogue is like buying "a pig in a bag". There is little objection to this with well-known, standardized manufactured goods. In such cases if you have seen one article you know what you are buying, because all of them are alike-made from 
the same raw materials, by the same processes, machines or moulds, and by the same producers. Few producers of standardized goods would willingly sell an inferior article or misrepresent it because their success depends on keeping their goods up to standard and telling the truth about them. But, as has been pointed out, there are practically no standards for perishables. And, with all due respect to farmers as a class, they have not yet seen the advantage of truthfully representing their goods or giving the quality and quantity they contract to give. ${ }^{1}$ Until the farmer gets to the point of representing his goods as they are and giving full measure he will have little chance to sell upon his representation of the goods. As yet so little progress has been made in standardizing perishables that selling by advertising is seriously handicapped.

Even if this were not so, the cost of advertising would be too great for the individual farmer. The cost of advertising a particular commodity is measured by the number of dollars worth sold through each dollar spent in advertising it. Whether advertising pays or not depends upon the relation of the money spent for it and the resultant gross sales. As the scale of the business increases, advertising, like manufacturing, is, up to a certain point, subject to a decreasing cost of production. The modern large shoe factory can make shoes at a much smaller cost per pair than can the individual shoe-maker or the very small factory. ${ }^{2}$ The large seller of a widely-used, standardized commodity, like typewriters or smoking tobacco, will get greater proportionate results by spending thousands of dollars for advertising than he would by spending a much smaller amount. The

1 The difference in business integrity between the farmer and the manufacturer is not a difference in inherent honesty or dishonesty, but a difference in business experience and education.

2 Van Hise, Concentration and Control, pp. 8-9. 
money spent by the extensive advertiser gives much greater returns proportionately than that spent by the small oneafter a certain point is reached the smaller the advertising the smaller the returns per dollar spent for it. The amount of perishables each farmer has to sell is too small and the supply too seasonal to permit him to advertise constantly and extensively. So the advertisement of the producer of this class of goods would be as costly when compared with the large seller's advertisement as is the shoe-maker's cost of producton compared with that of the large shoe factory.'

A seller who cannot hold customers after he has gone to the initial expense of getting them has little chance to succeed. The seasonable supply of perishables would make it practically impossible for the individual farmer to keep customers. A producer of tomatoes, or any other perishable would be able to supply a particular family with them for only a few weeks or months in the year, then this family would have to find another farmer who could supply the commodity for another period. and so it would go until each family would have to deal with three or four farmers during the year in order to get its supply of tomatoes. The same would be true with all other perishables consumed. This constant shifting of trade relations between farmers and consumers would make it very hard for a farmer to get back his old customers at the beginning of each season -they would have forgotten about him in the meantime

1 The U. S. Post Office Department has realized the impracticability of farmers' advertising for customers, so, in order to increase the use of parcel-post, it has offered to advertise for farmers free of charge. This Department gets the names and addresses of farmers who have perishables to sell (with a description of the goods offered) and gives out this information to consumers in the towns and cities. What results this free advertising has had, and the extent to which it has been used, is unknown to the writer, but doubtless it has resulted in some direct selling. It is extremely doubtful, however, if the public benefit equals the cost to the Government. 
or have been attracted by the advertisements of some other farmer. In order to keep customers the seller must be able to supply goods at all the times and seasons they are desired.

In spite of the many difficulties which stand in the way, it is not to be maintained that in all cases it is impossible or even impracticable for producers to find distant consumers who will buy their produce. In cases where farmers raise a good of special quality and flavor which has gained a reputation among a few select consumers they may be able to sell to such consumers without paying dearly for finding the market. The Albemarle Apple Growers of Virginia sell some of their apples direct to large hotels and restaurants in distant cities; some of the Long Island vegetables are sold by the producers direct to families in New York City. ${ }^{1}$ It is possible to enumerate several individual cases where eggs, chickens, butter, fruits, and vegetables are being sold direct to consumers 100,200 , or 500 miles away. These are all exceptional cases, where, for some special reasons, the buyers and sellers have been brought together. It should be clear, however, from our discussion of the difficulties in the way of finding such a market that these exceptions can never become the rule.

We have not yet considered the possibilities of direct trade relations between farmers and nearby consumers. What, if any, are the difficulties in the wav of farmers selling their perishables directly to families in the nearby cities? Why should not the city consumers be directly supplied by them with perishables? The answer is that there is already a considerable direct trade carried on between urban families and nearby farmers, especially in the smaller towns and cities, but that there are many very serious obstacles in the way of developing this trade to very much larger proportions.

${ }^{1}$ Fuller, Annals of Amer. Acad. of Pol. and Soc. Sci., vol. L, pp. I66-70. 
The farmers who live on farms near large cities, like New York, Chicago, Philadelphia, or even smaller cities the size of Atlanta, Oklahoma City, or Denver, have little better chances of coming in trade relations with the individual consumers in those cities than do farmers living hundreds of miles from them. The social and economic habits and customs of city families stand as barriers to neighboring farmers selling goods directly to them. City people perform most of their economic functions in machine-like, uniform fashion through systems and would not take the time and energy to deviate from this way of doing things. They pay their rents to agents of the landlords without, in many cases, ever seeing or hearing of the man who actually owns the house they live in. They buy their groceries from stores conveniently near them either by telephone or by visit to the store-and their other economic activities are just as uniform and systematic. Economic relations in the cities are so complex and the whole social fabric is so dependent on each doing his work efficiently and constantly that "systems" with complicated machinery must be organized to handle their economic wants and activities. The middleman machinery with its permanent wholesalers and retailers is the system on which they depend for their perishables. In this way they can get any kind or grade of these goods at any time and, at the same time, buy other necessary groceries. This takes little energy or thought on their part, while to buy from "peddling" farmers would require much time and trouble.

Nevertheless, many farmers sell some perishables to consumers in the small towns by house-to-house peddling. But this is a very expensive way of finding customers. If all suburban farmers attempted to peddle their goods there would be a useless competition between them and an unnecessary duplication of work-farmers having the same pro- 
ducts to sell would travel over the same streets and try to sell to the same customers. Such peddling is generally carried on in the busy seasons when the farmer's time is greatly needed on the farm.

If we count the time of a farmer and that of the wagon and team necessary for the peddling at only $\$ 3.50$ per day, the expense of delivery alone (to say nothing of that of getting the goods ready for market) would be as follows: if he sold only $\$ 3.50$ worth of goods in a day the cost would be Ioo per cent of what he received for the goods; if he sold $\$ 6.00$ worth the expense of delivery would be over 59 per cent of what he received for the goods; if he sold \$12.00 per day the expenses would be over 29 per cent. Those acquainted with house-to-house peddling will realize that few farmers will sell, on the average, more than $\$ 12.00$ worth per day. So the net price received by the peddling farmer for his goods (even when he can find a ready demand among consumers and loses nothing from decay) is hardly above the average price received by the neighboring farmer who sells through the middleman system.

In a few exceptional cases where suburban farmers are producing perishables which have a fairly continuous harvest-like butter, eggs, and chickens-and have established such trade relations that they have regular customers to whom they deliver the goods according to a prearranged schedule, direct dealing may be profitable to both producers and consumers. This kind of trade is not suited to fruits and vegetables however and only a few suburban farmers can secure such a line of regular customers for dairy and poultry products. The only reason that general peddling is now so common in the small towns is that there are no professional shippers who will buy the surplus goods after the local retailers have taken all they can handle. So it is generally the local surplus which is peddled, and the prices 
have necessarily been very low to the consumers. This is why many have gotten the idea this is really an economical method of marketing the goods. It may occasionally benefit the consumer who will take the trouble to buy from the farmers, but it is very expensive to the farmer.

In recent years there has been a movement in many of our American cities to have the municipal government establish market places where the farmers could drive in with their wagons and sell their perishables directly to consumers who come to the market. ${ }^{1}$ Such markets, to distinguish them from the municipal retail markets, are generally called "curb-markets." Sometimes towns provide sheds and stalls which farmers can rent for the purpose of displaying their goods and where the goods will be protected from the weather, but generally these markets are held on streets which are set aside for that purpose and the farmers drive in and sell their goods "from the tail ends of their wagons." These markets are intended to eliminate the unnecessary work of peddling and to encourage a larger amount of direct dealings between consumers and nearby farmers than has been carried on in the past. There are many very serious obstacles in the way of the wide success of such curbmarkets.

It is very hard to induce consumers to go to such markets to buy their perishables even when the price-offers are much lower than the prices for the same goods at the corner grocery or fruit stand. In the small towns there can be only one curb market, and in the very large cities only two or three, so the great majority of the consumers necessarily live a considerable distance from them. The time taken up in going to and from such markets and the cost of the trip prevent most consumers from becoming regular cus-

${ }^{1}$ Report of Mayor's Market Commission of New York City, pp. 67-84. 
tomers-the housewife will not take up an hour or so of her time each day in making the trips to these markets. It is so much easier and more convenient to telephone the order to the nearby store and have the goods delivered to her kitchen.

Where these markets are successful-that is, where farmers drive in and offer their goods for sale and where consumers patronize them-the success generally lasts for but one harvesting season. They must die during the winter months when the farmers have no perishables to sell. So by the next harvesting season consumers have gotten out of the habit of going to the market and they are less enthusiastic over the idea. ${ }^{1}$

In a great number of these markets, which have been recently established in the various cities, farmers have been replaced as sellers by professional retailers who buy the goods from the farmers or from wholesalers. ${ }^{2}$ The reason for this is not hard to find: It is because professional retailers can sell the goods at a less cost than can the farmers themselves. The individual farmer offering his goods in one of these markets is greatly handicapped because of the small variety he can offer. The professional retailer who buys a wide variety of perishables from several farmers and wholesalers is enabled to make a very much greater number of sales in a given time than can an individual farmer who is offering only the few products that he has for market. Again, the farmer loses very valuable time from his farm in trying to sell his goods at these markets. He soon realizes that he can make more by selling his pro-

1 This is certainly true with many of the curb markets of the MiddleWestern towns, and, as far as can be learned, of Eastern towns.

2 This fact is recognized by most of the advocates of curb markets, but few such advocates know the economic reason. (See King, Lower Living Costs in Cities, p. 26.) 
duce to the professional retailer, whose expense per sale is much less than his own, than by trying to sell to consumers in competition with the professional. So, the curb market, instead of being a market where consumers can buy directly from farmers generally becomes a market where consumers buy from professional retailers.

While the possibilities of establishing direct trade relations between nearby producers and consumers are usually greater than where they are widely separated, the cost of bringing them together is, on the average, as great or greater than the total cost of marketing the same goods through the middleman system. Because of this fact such marketing will not develop to a very great extent in the future. About the only good it can ever accomplish is to limit some of the occasional unfair practices of private middlemen, and, as we hope to show, such unfairness could be eliminated by less expensive remedies.

\section{B. Transferring the Goods to Consumers: Direct is. Middleman Methods}

In the exceptional cases where it is possible for farmers to find distant consumers who will buy their goods the expenses connected with completing the transactions are very heavy. It is necessary for them to grade and pack the commodities in small individual packages; to address and deliver each package to the transporting agencies; to pay the enormously high rate for transportation-which, in many cases, equals the total cost of marketing through the middleman system; ${ }^{1}$ - to stand the heavy losses from deterioration while the goods are on the way: and to carry on a correspondence by mail in regard to financial settlement. So, even if it were possible to establish direct trade

${ }^{1}$ See Discussion of Express and Parcel-Post Rates, pp. 63-64. 
relations with distant consumers easily, the costs of carrying on the trade would generally be prohibitive.

In the case of direct trade between consumers and suburban farmers, it is not possible to separate sharply the expenses of finding the market and those of transferring the goods to the consumers because the deliveries are made in person by the farmers. However, in this case there are few expenses of grading and packing (as the trade is now carried on) and no expenses of collection, though the losses from decay are generally heavy because of the exposure of the goods and the lack of ready buyers. The time taken to find the market and to make the deliveries, as we have seen, makes this method of marketing very expensive.

If it were possible to institute direct marketing on a large scale different prices would have to be set for each separate transaction. The fluctuations in the prices which each farmer would receive and the prices each consumer would have to pay would be much wider and more violent than they are to-day. ${ }^{1}$ The losses from decay would also be much heavier because of the difficulty of quickly bringing together immediate physical supply and actual demand, and lack of storage facilities for caring for the goods.

\section{Economic Value of. Marketing Machinery for Perishables}

If all marketing can not be carried on directly, it follows that we must have some kind of marketing machinery or system to perform this work. Those who have so strenuously advocated the abolition of the present complicated machinery have overlooked the great advantages of division of labor in large-scale production. ${ }^{2}$ Just as shoes can be

1 The changes in prices of perishables in the country town to-day will illustrate this point.

y "There appears to be no reason why this specialization argument 
produced more cheaply through the factory system where there is minute division of labor than by the individual cobbler, perishables can be marketed more cheaply through a marketing system which has minute division of labor than through direct marketing. Division of labor in marketing affords constant and specialized occupation for those engaged in the work, the continuous use of the capital invested, and a consequent low expense per unit of goods handled. When a farmer attempts to market all his perishables directly he is fighting against the "factory system of marketing" just as the individual shoe-maker for a long time fought against the factory system of manufacturing shoes.

In order so to widen the market that the immediate physical surplus of one section can be moved to fill a deficiency in supply in other sections, the present marketing system with its primary, wholesale and retail markets has been built up. This machinery is now largely in the hands of private middlemen, and that is why we speak of the " middleman system". Whether we retain this machinery or adopt some other; whether we have the machinery run by private middlemen or by agents of coöperative associations, we must have some kind of marketing machinery run by some kind of marketing operators. It is pretty certain that we shall find it the best policy to retain the essential features of the present machinery because, as has been well said, "The present distributive machinery, with all its strong points and its weaknesses, has been created of necessity, and it has weathered the storm of much adverse criticism, because every part of the country is now enjoying the perishable products of the most remote districts." 1

should not apply to the creation of time, place, and possession utilities in the marketing process as well as to the creation of form utilities." Weld, Minnesota University Bulletin No. 4, p. 4.

${ }^{1}$ U. S. Dept. of Agri., Bul. No. 267, p. 3. 
III. REDUCTION OF THE COST OF MARKETING THROUGH SIMPLIFICATION OF THE PROCESSES

We now find it advantageous to market some goods more directly than others-that is, to pass them through a fewer number of markets, or through the hands of a fewer number of operators-and there is no reason why we should not continue to market different goods by different routes. It is also probable that we shall discover that certain marketing operations which are now carried on can be dispensed with in some cases-for example, commission merchants and brokers might be replaced in small markets, by having carlot dealers combine this work with their own. However, much of the talk that we so often hear advocating " shorter marketing routes" or " more direct marketing" has little economic justification. ${ }^{1}$ An examination of the difficulties to be faced in establishing some of these " shorter routes" will make this evident.

\section{A. Sales by Producers}

I. To Local Retailers. Many farmers living near towns sell directly to the retail merchants in those towns. In such cases the farmer delivers the goods by wagon directly to the store of the retailer or the retailer sends his wagon out to the farm, buys the produce and hauls it in. Why cannot this kind of trade be developed to greater proportions?

Where it is easy and convenient for merchants to buy their perishables from wholesale dealers (that is, where wholesale markets are accessible to them) they generally will not buy direct from farmers unless they can get the produce at far below wholesale prices. This is true because

'See ch. viii, "A Shorter Route from Producer to Consumer," of King's Lower Living Costs in Cities, as an example of some of these proposals. 
such trade is very troublesome and unsatisfactory to the retail merchants. The quality of goods raised by each farmer varies greatly; for example, in one day's gathering of tomatoes every grade from culls to AI may be found. The trade of the retailer demands one or two fairly definite grades, and, as few farmers ever grade their goods before selling, the retailer who buys must grade them-which means that he will be able to sell only a part of the goods he buys. Again, the merchant who buys his supply of perishables from farmers necessarily has to deal with many different ones to get the various kinds of goods which he handles. This entails many small, individual business transactions for him, whereas he can go to the wholesale trade and buy just what he wants in one deal. Consequently, retailers are averse, as a rule, to buying from local farmers -except at bargain prices.

In many other respects such trade is very unsatisfactory to both retailers and farmers. In the small towns, where it is carried on to the greatest extent, when the local supply is greater than the local demand the competition between farmers so depresses prices that the trade proves very unprofitable to them. Trade relations, when once established, are not permanent, but must be re-established each season, because between the local harvesting times the merchants have to look elsewhere for their supply. So at the beginning of each season the farmers must form new business connections or re-establish the old ones.

To-day there are only three conditions under which this kind of trade is carried on to any great extent. First, in the small towns where the farmers have no primary markets for shipping their goods and where there is no wholesale market, or at best a very poor one, on which merchants can depend for their supply of perishables, this trade is tolerated Decause they have nothing better. It is unsatisfactory to 
both merchants and farmers. ${ }^{1}$ Second, where there are very large retail stores, and chain-stores which have a diversified trade so that they can afford to buy the ungraded goods from farmers, grade and sell them in the many stores. This kind of trade is generally profitable to farmers, merchants and consumers. Third, where farmers sell to retailers in municipal retail markets-the profitableness of which depends on the success of the retail markets.

2. To Distant Retailers. In addition to having to face most of the difficulties of selling to nearby retailers, the farmer who attempts to sell his goods to distant retailers is confronted with several other problems which make this kind of trade practically impossible. He has no better way of forming trade relations with them than with distant consumers; even if he does get in communication with them they will not buy his goods without first seeing them-so he must ship the goods and have a representative at the destination to look after his interest. Where he is not represented in such transactions he must accept the merchants' statements as to the condition of the goods on arrival. He can not ship in car-lots because very few retailers handle perishables in such quantities. If he sends smaller quantities he has to pay much higher transportation rates. And lastly, the farmer who attempts to sell to distant retailers must have expert knowledge of the shipping business; he must know how to deal with the transportation companies in getting adequate accommodations; he must grade and pack his produce for shipment; and, finally, he must attend to making sales and collections. Under such conditions, this trade can never develop to any considerable extent.

- Price fluctuations are more violent than for the goods which pass through wholesale markets. 
3. To Wholesale Markets. Many individual farmers to-day sell their own goods in the wholesale markets without the aid of country shippers or shipping organizations. Such sales are generally made by large producers who can ship in car-lots. If an individual farmer can not ship in carlots, in most cases it will be to his advantage to turn his goods over to professional shippers or shipping organizations who will send his produce, along with that of other farmers, in car-lots to the wholesale markets. When these sales are made the goods are generally sent to commission men or to brokers who sell for the shipping farmers. Occasionally they ship to car-lot dealers under contracts where the price is fixed after the goods arrive at the wholesale market and have been inspected by the dealers. In this case the farmer is compelled to accept the price prevailing in the market upon the arrival of his goods and take the risk of the dealer's making a false report to him as to the current price or the condition of the goods upon arrival. In most cases such risks are too great, so farmers generally ship to brokers or to commission men who act as their representatives in making the sales. It occasionally happens that car-lot dealers send out their own representatives to buy the goods from farmers, delivered on track at the shipping point. In this case the price is certain and the farmer gets his money immediately without assuming any more risks. However, selling to representatives of wholesale men at the shipping point is limited to a few commodities, like apples and potatoes, and is only possible for farmers living in the principal producing sections-wholesalers can not afford to send representatives to districts that do not ship several cars per season.

There can be no question of the great economic value to each producing section of efficient country shipping agencies, to which the majority of the farmers in the community 
can turn over their goods for marketing. These agencies, by handling most of the goods of the community, can employ specialists for grading and packing; they can supply adequate storage facilities; keep in touch with the market situation; ship in car-lots and deal more advantageously with the railroads and wholesale dealers. When the farmer attempts to sell his goods in the wholesale markets he assumes all the functions and risks of the professional country shipper. He generally knows little about this work and his scale of business is so small that the expense per unit of business is very great, consequently he usually finds that his time can be more profitably employed by turning the marketing over to the professional shipper and devoting himself to production.

4. To "Wholesalers" in Small Towns. There are comparatively few farmers, or shippers either, for that matter, who sell any perishables to the wholesale dealers in the small towns. These wholesalers, like the jobbers in the large wholesale centers, buy most of the perishables they handle from the car-lot dealers in the larger cities. To many it looks like a useless complication and duplication of work to have the produce shipped from the primary markets to the large wholesale markets and then back to some wholesalers in a nearby town. But there are several reasons why this seemingly useless, roundabout method is more economical for the shipping farmers or the professional shippers than selling directly to such wholesalers.

The special business of the small-town wholesaler is to sell goods to retailers just as does the jobber in the large city. He can make more through buying all his perishables from a few car-lot dealers in the large centers and devoting most of his time to the selling end of his business than by taking up his time to carry on business relations with many shippers and farmers in many different sections of the coun- 
try. He can always buy just the grade of goods and in the quantities he wants at the particular time he wants them from the large wholesale markets, while if he bought from farmers he would have to take the goods at irregular intervals and would be uncertain of the grade he would get. Few farmers or shippers could furnish cars of perishables containing the different kinds of perishables demanded by the small wholesalers, and few such wholesalers could handle solid cars of any one perishable-as a care of cabbage, of peaches, etc. To ship to them in less than car-lots would be too expensive.

The larger the wholesale market the more constant will be the prices-because of the law of average. The markets of the small towns are so limited in size that, under our present meager marketing information, if shippers attempted to supply them directly they would be in a constant state of glut or scarcity and the price uncertainty would make the business very unsatisfactory.

\section{B. Sales by Professional Shippers}

Country shipping agencies would find the same difficulties in selling and shipping their goods direct to retailers as do individual farmers. Seasonal supply and variability in quality of goods handled by shippers, economy of car-lot shipments, the difficulties in the way of establishing business relations with retailers, and many other business factors will keep this kind of trade from being satisfactory to either shipper or retail merchant. They would also find the same difficulties in selling to country-town wholesalers. In cases where shippers are doing a business sufficient to enable them to have their own representatives in wholesale markets it might happen occasionally that those representatives would be able to sell directly to retailers. On the whole, however, it is more economic for shippers to sell their produce in the wholesale markets. 
A larger proportion of shippers to-day are selling their goods to car-lot dealers without the intermediation of brokers and commission men than ever before. This has been made possible for two reasons: First, several perishables like butter, poultry, eggs, potatoes and apples have become standardized to the degree that there can be little question as to their condition and grade when they enter the wholesale market and their price quotations are fairly definite and easily ascertained by the shipper. Under such conditions there is little chance for car-lot dealers to make false statements to the shippers as to condition of goods upon arrival or as to the current price quotations in order to get the goods at a sacrifice price. Second, many shipping agencies have become so large that they are enabled to station their own representatives at the wholesale markets to look after their own interests when they make sales to carlot dealers. However, the great majority of perishables are far from being standardized and only a few shipping agencies are large enough to station their own representative in the wholesale markets, so it is still necessary for many of them to continue to sell through brokers and commission men who are supposed to represent their interest.

The not infrequent failure of commission men actually to represent the interest of shippers (by making fictitious sales, giving false returns as to prices received, and padding expense accounts) has been a large factor in decreasing the amount of business done through them. The organization of public auction markets where shippers send fruits and vegetables to be sold under licensed auctioneers has also had some weight in supplanting commission men and brokers. Nevertheless, a very large proportion of shippers still need some one to represent them in the wholesale markets and the commission men, unsatisfactory as they often are, are the best representatives now available. 
Besides representing the interests of shippers, brokers and commission men perform the additional economic service of receiving mixed and less-than-car-lot shipments of perishables. They separate these goods from each other and sell each kind to the car-lot dealer who specializes in that particular produce. Many producers make such shipments, as they do not have enough of any one commodity for a car load, but they can not send these to car-lot dealers because each dealer only handles certain perishables.

\section{Purchases by Retailers}

We have seen that only in special cases is it possible for farmers to sell directly to retailers and that when such trade is carried on it is generally unprofitable to either one or both of them. It was also shown, that, for the same reason, trade between professional shippers and retailers can never develop to great proportions. As to whether it would be more economical for retailers to buy their perishables from auctioneers, commission men, car-lot dealers, or jobbers will depend (I) on the character and size of the business of the retailer, (2) on the size of the town in which he is doing business.

I. From Auctioneers. Of course, merchants in small towns cannot buy from auctioneers because such markets exist only in the large wholesale centers. In these markets the goods are generally sold in very large lots (car-lots, roo bbls., cartons, or cases, I,000 lbs., etc.) so that only the big retailers can afford to buy goods in such quantities. Where goods are sold in smaller lots it is hard for merchants to be sure that they are buying the grade of goods demanded by their trade-much of the perishables auctioned off in small lots are damaged goods which large wholesale dealers do not care to handle. Again, visiting auction markets (which are generally a considerable distance away) requires a great 
deal of the retailer's time which could be spent profitably at his store-unless the auction is held before the opening hours of the stores, as most fruit auctions are now held. So there are only three classes of merchants in the large cities who find it profitable to buy from auctioneers. First, the large chain-stores which can afford to buy in great quantities, re-grade and sell the different grades, in the stores which handle such. Second, the fruit and vegetable hucksters who handle only a few unclassified perishables and whose time is not needed at an established place of business. Third, the dealers in the municipal retail markets which are situated in close proximity to the auction markets. Most other merchants find it more economical to buy from the jobbers or other wholesale men.

2. From Commission Men and Car-lot Dealers. The merchant in the large city who buys from commission men or car-lot dealers must buy in large quantities (because these dealers sell only in large lots) ; and he must buy from several different dealers (because they specialize in the variety of goods they handle). Few retailers have time, or a large enough business to form trade relations with more than a half-dozen different dealers. They can buy from the jobbers, who solicit their business, not only the exact amount and grade of each product they desire, but in one transaction with one jobber they can buy all the different kinds of perishables they handle. Most retailers buy on a credit and in buying from one or two jobbers they find it easier to arrange for this than they would if they bought from a dozen or so commission men and car-lot dealers.

Of course, it is even harder for retailers in the small towns to buy from car-lot dealers than for those in cities, because they are so far removed from the large wholesale centers. Therefore, most country retailers must buy from local wholesalers just as city retailers buy from jobbers. 
IV. SIMPLIFICATION OF MARKETING PROCESSES THROUGH CO-OPERATION AND MUNICIPAL MARKETS

\section{A. Farmers' Co-operative Marketing Associations}

Many enthusiastic advocates of farmers' coöperative marketing associations have the impression that marketing processes can be greatly simplified and goods made to pass much more directly between producers and consumers through these associations. A little analysis of the proposition in the light of the immediately preceding discussion will show that such associations can do little to simplify marketing processes or to bring the producers much nearer consumers.

If we think of direct marketing in terms of the number of "middlemen" through whose hands the goods pass on tneir way to consumers, instead of the number of marketing processes through which they pass, it is clearly evident that marketing through farmers' coöperative associations is one step toward direct marketing because it eliminates the private country shipper. But it does not do away with the work which is now performed by the private shipper; it only transfers those processes to a different agency. In other words, the coöperative association carries on the work of the private shipper-that of disposing of the farmers' products at the highest net price possible.

There is no reason to believe that a farmers' coöperative marketing association handling the same amount of perishables as a private country shipper, would be able to sell its goods more directly to consumers than would the private shipper. The same markets and the same market facilities are equally available to both, and if it would be advantageous for the coöperative association to market its goods in a direct fashion it certainly would be just as advantageous for the private shipper to market by similar pro- 
cesses. We have seen that in a great majority of cases the shipping agencies find it more economical to sell their goods in the wholesale markets-this principle will apply regardless of the character of the shipper.

We have seen that shipping agencies which do a very large business are enabled to dispense with the employment of private brokers and commission men because they can sell through their own representatives in the large wholesale markets. The California Fruit Growers' Exchange and several other large coöperative shipping associations now sell through their own representatives in New York, Chicago and other large markets. ${ }^{1}$ This, of course, is not a simplification of the marketing processes, it is only substituting one agency for the other in performing the same work. And such substitutions can be made only when very large coöperative associations are organized to take over the work now performed by several small private country shippers. So, on the whole, we find that farmers' cooperative marketing associations can do little or nothing in the way of simplifying the marketing processes-they find it more economical to adopt the same methods as are used by the private middlemen.

\section{B. Consumers' Coöperative Stores}

It is easy to see that if consumers' coöperative stores could be developed to the extent to which they have been in England and in Scotland they would be able to organize their own wholesale associations and thus eliminate the private wholesalers. ${ }^{2}$ Even if they did not organize their own wholesale markets the very large coöperative associations would, like the large private chain-stores at present, be able to buy more directly-either from farmers, shippers,

1 Proceedings of U.S. Dept. of Agri. Marketing Conference, p. 5.

${ }^{2}$ Senate Doc. No. 214, 63d Cong., Ist ses., pp. 787-9o. 
or car-lot dealers. But they could affect the marketing processes only in proportion to their ability to become larger business units than are the present private retail stores. There is no reason to believe that a coöperative store the same size as a private store would be able to buy any more directly. Even in the cases where the large coöperative stores would be able to buy more directly, they would not simplify the marketing processes, but would only substitute their own agents for the present private agents. So, granting that there are no difficulties in the way of organizing such associations, it is hard to see that they would be able to do much to simplify marketing.

\section{Municipal Markets}

In discussing the limitations of direct dealings between producers and consumers we pointed out the serious limitations which confront the municipal curb-stone market as an institution for shortening the route between the producers and consumers. In the ordinary municipal retail market where professional retailers are licensed to carry on business, they will generally buy their goods in the same ways as the ordinary corner grocer does to-day-from jobbers, principally. The wholesale municipal markets are not even intended to shorten the route between producer and consumer, their object is to regulate the methods of performing the ordinary marketing processes.

\section{SUMMARY}

The present division of labor and complicated processes of marketing perishables have developed because, as the trade in these commodities grew and as the market expanded, it was found that the goods could be marketed more cheaply and efficiently by division of labor and specialization than by the simpler and more direct methods which 
were used when the trade was seasonal and local. On the whole, we find that these processes cannot now be very much simplified either by producers, consumers, private middlemen or coöperative associations-that is, simplification of the processes will not lessen the social burden entailed in marketing the goods.

If we are to reduce the social costs of marketing perishables through a reform in the system of marketing, it must be done by finding cheaper and more efficient ways of performing the complicated processes-not by reducing the number of those processes. The next chapter will deal with the possibilities of this reform-that is, with other methods of running the marketing machinery. 


\section{CHAPTER V}

Reduction of the Costs of Performing the Marketing Processes

Even though we do not find it possible to greatly reduce the social costs of marketing perishables by reducing the processes or simplifying the machinery, we may find that the desired results can be accomplished by the adoption of cheaper and more efficient ways of carrying on the complicated marketing processes. In attempting to accomplish these results there are three general lines of action which may be followed. First, the national, state and municipal governments may, through marketing departments or bureaus, coöperate with, and regulate the methods and practices of, those engaged in the marketing business. Second, private middlemen may be supplanted by coöperative associations which carry on the work at less cost. Third, the costs may be reduced by the elimination of inefficient practices through competition between the marketing agencies. Let us see to what extent the costs of marketing perishables may be reduced by the adoption of each of these lines of action.

I. THROUGH GOVERNMENT MARKET DEPARTMENTS OR BUREAUS

We will suppose that the powers of the present Office of Markets of the Department of Agriculture are extended over the interstate commerce in perishables so that this office will have somewhat the same powers over trade in 493] 
these goods that the Interstate Commerce Commission now has over the interstate transportation business. Let us suppose further that each state and each municipality has established a department of markets to regulate the local and the state trade in these goods, just as the public service commissions regulate the public service corporations. What could, or what should, such government agencies do to improve marketing and reduce its costs? This question can be answered only by a discussion of the influence of government regulation on some of the present defective business methods and practices of the trade.

\section{A. Standardization of. Grades and Packages}

It has been shown that if we had more uniform grades for different perishables and that if they were shipped in more uniform-sized containers much of the loss from decay would be eliminated and the expense of re-grading and repacking would be greatly reduced. Again, as has been pointed out, we can never get accurate market information from the different wholesale markets as to receipts and prices until we reduce these commodities to uniform units of commerce-at present it is not possible to get the information as to the daily receipts of most perishables in the wholesale markets because they arrive in so many different-sized packages and grades. It goes without saying that we can never hope to get much uniformity in grades and packages unless it is forced on the trade by government action. So the only question which faces us in this regard is the possibility of establishing national uniform grades and packages for these goods, that is, whether the government experts would be able to prescribe uniform standards which would be of much service.

There is no reason why uniform-sized packages can not be made for each perishable which enters commerce. At 
the present time we have a national law which requires a standard barrel for all apples which enter interstate commerce. $^{1}$ Five or six of our states have regulations concerning uniform packages for some perishables. ${ }^{2}$ These state regulations are of some service within the state, but, as the packages of one state differ from those of the others, they do little to bring about uniformity in packages of interstate commerce. After investigating the subject of the most desirable size of package for each perishable, it would be easy for the Office of Markets, if given the power to do so, to formulate and enforce the use of a national standard package for each perishable-in some cases it would be best to make the unit a quart, in others a bushel, or 100 or I000 pounds. The standard packages which are prescribed by the Office of Markets for interstate commerce should then be adopted by the state and municipal departments of markets and enforced for state and local trade.

It would not be as easy to establish uniform grades for all perishables as it would be to establish uniform-sized packages for them. Still we have many perishables, such as butter, milk, eggs, chickens, potatoes, apples, oranges and some others, which can be divided into fairly definite grades. As a matter of fact, each wholesale market now has its own grades for these goods and many shippers have their grades for them. The difficulty is that there is little or no uniformity among the grades adopted by different shippers and wholesale markets. ${ }^{3}$ We need a national schedule of grades for each of these products so that re-grading will

1 A copy of the law is to be found in Appendix A.

${ }^{2}$ Washington, Oregon, California, Illinois, Texas and Virginia all provide that the Secretary of Agriculture or Horticulture shall formulate standard packages for certain perishables.

${ }^{3}$ Some of the Pacific States have adopted uniform state grades for a few articles-this is true of Washington and Oregon. 
not be necessary as they pass from one market to another or from one middleman to another. If the Office of Markets were given the power to prescribe and enforce standard grades for all these goods which enter interstate commerce and if the national grades were accepted and enforced by the state and municipal departments of markets for local commerce, their marketing would be much improved and millions of dollars would be saved in re-grading.

When we come to such fruits and vegetables as peaches, celery, watermelons and many other highly perishable commodities the question of uniform grades is a much more difficult one. There are so many varieties of each of these goods, their quality varies so greatly from season to season and from section to section, and they are so highly perishable that it would be very hard to establish exact grades for any one of them. However, this does not mean that much progress can not be made along this line. Each can be graded at the shipping point according to size, soundness, color, variety and so on, so that fairly definite grades for each will be recognized in the markets. These grades could be worked out by the Office of Markets in coöperation with state and municipal departments of markets and the men engaged in the marketing business. Like the grades for eggs, butter and the other goods already discussed these national grades should be adopted by the state and municipal departments of markets.

It might be argued that the establishment of standard grades for such highly perishable goods would be of little practical value because their deterioration is so rapid that they must continue to be re-graded as they pass from one market to another. No one package would have to be regraded more than once-whereas now they are sometimes re-graded two or three times by various wholesalers. The only question for dispute between shipper and wholesale 
receiver which could arise in regard to the goods, would be as to the amount of deterioration; and this question would not prove a difficult one with the proper regulation and inspection of middlemen by the Office of Markets and departments of markets.

\section{B. Elimination of Unfair Business Practices}

There has been a recent tendency in a few states to pass laws to regulate the business practices of middlemen engaged in marketing perishables. Washington, Oregon, California, Ohio, Virginia, Illinois, New York, and Texas have passed laws providing for either the bonding or the licensing of commission men and jobbing houses. Most of these laws contain provisions which are intended to eliminate certain abuses practised by these middlemen. The main points of these state regulations have been summarized by Professor King as follows: ${ }^{1}$

I. Specific definitions as to embezzlement and fraud with definite punishments therefor.

2. A provision that all persons, firms and corporations engaged in selling agricultural produce on commission should take out a license from the secretary of agriculture or some other specific state official.

3. A stipulation that each of these persons, firms or corporations so licensed should file a bond for a stated sum conditioned upon the payment of all moneys owing to farmers who have consigned agricultural produce to them.

4. Provisions prescribing the forms for the books to be kept by such commission merchants, and requiring these books to be open for inspection both by the shipper and by a particular state official such as the secretary of agriculture, or his duly authorized agent.

5. Provisions requiring detailed reports to be submitted to

${ }^{1}$ Lower Living Costs in Cities, p. 64. 
farmers and to the secretary of agriculture covering the condition in which the produce was received, the state of the market, price received, etc.

6. An informal and inexpensive means by which the farmer can investigate any complaints as to services or prices and secure redress when neglect or fraud seems evident.

These laws provide heavy penalties for those who violate any of their provisions.

Such laws are very beneficial as far as they go, but they are defective because of their limitations. These laws do not affect the business practices of car-lot dealers, jobbers and retailers, but apply only to one class of middlemen. They also apply only to transactions of brokers or commission men with farmers or shippers within the state and not to transactions between parties in different stateswhereas the larger part of such business is interstate.

In order to eliminate the present dishonest dealings in the trade and to reduce the business practices and customs to uniformity throughout the country, effective government regulation must be applied to all classes of middlemen from shipper to retailer. The Office of Markets should be given regulative power over all kinds of interstate transactions in perishables similar to those given the state secretary of agriculture over the intrastate transactions of brokers and commission men in the laws outlined above. The state departments of markets (or the state secretary of agriculture) should not only exercise regulation over the intrastate business of brokers and commission men, but they should have the same control over the business of car-lot dealers and jobbers. The municipal departments of markets should have regulative control over the business of retailers in regard to weights, measures and the soundness of the goods sold. These municipal markets should publish 
the wholesale prices from day to day to let the people know what the retailers are paying for the goods they are selling.

The Office of Markets and each state and municipal department of markets must have sufficient appropriations and assistants properly to enforce the regulative powers which are given them. Each state and local department should work in harmony with the Office of Markets-their work should be complementary, not conflicting. The powers of the different state departments should be the same in each state, and so should those of the municipal departments.

With such regulation the misquoting of prices, false reports as to condition of goods upon receipt, bogus sales, cornering of the market and other unfair practices would become negligible. The middlemen would gain greater confidence of both farmers and consumers, while, not least of all, the business practices and customs of the trade would be reduced to uniformity-and uniformity generally means efficiency.

As a rule, middlemen object to government regulation of their business just as the railroads objected to being controlled by the Interstate Commerce Commission. It is almost inevitable that when a man is making money in a business under certain conditions (no matter how bad those conditions may be) he objects to any interference or regulation which will affect that business. The action of the country bankers in convention at Boston, just prior to the passage of the present Federal Reserve Act, in passing a resolution condemning the provisions of that act, is a good illustration of the attitude business men take toward any legislation affecting their business, even though the legislation may be very helpful to the business. In the states where regulation has been applied to commission men and jobbers, they agree that, as a whole, it has been 
helpful to the trade. ${ }^{1}$ There is little reason to believe that a more comprehensive regulation of the practices of all middlemen will not be beneficial to the whole trade in perishables just as regulation has been helpful to the transportation business.

\section{Organizing Market Information}

At the conference on markets held by the Secretary of Agriculture in Washington on April 29, I9I3, the question of a market reporting system for perishables being organized by the Department of Agriculture received much discussion. Again, in Report 98 of the Secretary's Office the question is taken up in more detail. It was the prevailing opinion at the conference that the problem was too great for the department to tackle at that time, and some doubts were expressed as to whether such a reporting system would be of great value to the trade. Upon the cost of organizing and maintaining a thorough reporting system Report 98 says: ${ }^{2}$

If the Department were to take charge of any feature of the marketing of farm products, if it were to perform the duty of finding customers or markets, if it were to perform the duty of ascertaining market conditions and prices every day in all principal markets and undertake to make the information serviceable to farmers throughout the country, the expense of such undertakings would be practically prohibitive.

Take the matter of trade news at trade centers. To maintain a service of this sort it would be necessary to employ men at trade centers to be in constant touch with their markets and to report by telegraph daily or oftener the prices of farm products and the state of the market with regard to supplies.

${ }^{1}$ King, Lower Living Costs in Cities, p. 69.

2 Page I9. 
The cost of this service would be enormous. There is a farmers' coöperative association for marketing vegetables on the eastern shore of Virginia that expends $\$ 25,000$ a year for telegraphing, and yet this association covers only two counties of ordinary size. The great association of California citrus fruit growers for marketing oranges and lemons spends $\$ 75,-$

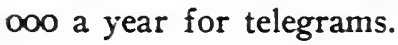

\section{Telegraphic Service}

If a Division of Markets were to do telegraphic service for principal farm products and for the whole country, it seems certain that the cost would be a million dollars or more yearly. This is the conclusion that is indicated by the experience of the two associations just mentioned.

In regard to the practicability of such a reporting system the same report continues: ${ }^{1}$

The matter of performing a telegraphic service has consequences which must inevitably follow. Suppose, for instance, that a Division of Markets were collecting information by telegraph concerning prices and market conditions at trade centers and were to publish the report that there was a scarcity of a certain product in a certain market and that prices were high enough to be extremely profitable to producers. It is likely that producers having no market associations, who were able to reach the market reported as being in a state of scarcity and high prices, would send to that market quantities of the products sufficient to create a state of glut.

The individual producers and shippers would not be under the control of any coördinating power, and in order that news supplied to them by the Department might be made useful it would be necessary for the Department to perform the duties of a director of shipments in order that markets might not be glutted.

As will be observed in reading the descriptions of the systems

1 Page 19. 
of marketing by coöperative associations on subsequent pages, these associations are in no need of a telegraphic service performed by the government.

The above statements would indicate that the writer did not have a correct conception of how marketing is carried on at the shipping points at present. He speaks as if most of the goods are shipped by individual farmers, but as a matter of fact, only a very small percentage of them are thus shipped-at least 90 per cent of the perishables which arrive at the wholesale markets are sent by private shippers or cooperative associations. He seems to think that because these large associations and private shippers taken together spend hundreds of thousands of dollars to get their present meager and inaccurate market information, they do not need any better and cheaper service along this line-that only the individual farmer, who rarely ships for himself, needs the information. If the government can furnish better and cheaper service to the shippers than they now get, there is little reason why it should not do so.

He further assumes that government information of receipts, prices and market conditions at wholesale centers would only tend to cause those markets reported favorably to be glutted by the shipping farmers, and that the government would have to direct shipments in order to make the information serviceable. If the government report furnished only information as to wholesale markets and did not give an account of the shipments and intended destination of goods sent from the shipping points, there might at first be a tendency, as he suggests, to over-supply the favorably reported markets. But if the report is complete (giving daily receipts, prices and shipments made to each market) there is little reason why the government would have to direct shipments, or why the report would not be very valuable to the trade as a whole. 
In spite of the previous official mistrust of the advisableness and practicability of the department's furnishing any market information, the Office of Markets last year organized a market-information service for strawberries, cantaloups and peaches. In Appendix B is given a copy of one of the daily reports issued by this Office on peach movements for one day. On the whole this experiment on the part of the Office was successful, but it was very much hampered because of its newness and lack of sufficient funds. A few wholesale men in the large centers were displeased with the service because it upset some of their established practices, but the majority of producers and shippers were well pleased with the results.

There is, however, one very serious problem in regard to furnishing a complete market-reporting service for all perishables-such service, as has been suggested, would be quite expensive and hard to organize. But, through the coöperation of the Office of Markets with the state and municipal departments of markets, it would be possible to furnish complete market information, in regard to this class of goods, at a reasonable cost. It might be done somewhat as follows:

The information as to prices and receipts in the wholesale markets could be gathered by the combined work of the representatives of the Office of Markets, and of the state and municipal market departments. At the shipping centers the daily amount of shipments and their intended destination could be reported through the coöperation of state departments and the Office of Markets. For its part, the Office of Markets might use the county farm demonstrator whom the Department of Agriculture now keeps in practically every county in the United States. These men could gather this information in addition to performing their regular work. After the information is gathered it should not be neces- 
sary for the reporters at the various markets to telegraph it directly to Washington. All reporters in each state should send their information to a central market in that stateeither to the office of the state department of agriculture or, in case the state does not have such a department, to the state agricultural college. At this office the information should be tabulated and telegraphed to the Office of Markets at Washington. Here the report for the nation would be made-up and a copy sent by wire to the different state offices. From these state offices the information could be distributed to the shipping, wholesale and retail markets.

Representatives of the Office of Markets and of the state and municipal market departments (where such departments exist) should be kept at the wholesale markets as inspectors and administrators, as has already been mentioned, and it would add no extra expense to have these men gather the material for the market report. As far as the primary markets are concerned, it would cost little or nothing extra to have the county demonstrators gather the market information there. The reports from the different markets could be transmitted to the central state offices by telephone, mail and, occasionally, telegraph, according to the distance and circumstances. Only forty-eight telegrams would need to be sent to Washington-one from each state office-and Washington would have to send only one telegram to each of those offices. The problem of distributing the market reports from the different state offices to those engaged in the trade would not be very difficult. It would be given to the daily press of the state for publication, many of the different markets could be reached quickly by mail and, in some cases, the telephone and telegraph would have to be used. As a whole, the service should not cost much more than one and one-half millions per year.

It may be maintained that the above outline of a market 
reporting system is visionary because it depends upon the coöperation of state and municipal market departments which are not yet established; and further, that if such market departments were established, they probably would not coopperate along this line with the Office of Markets at Washington. It is true it would take some time to establish such governmental machinery, but, for other reasons than market reporting, we should have a department of markets for each state and a municipal department for all large cities. The laws creating them should be uniform in all states and should be drawn in such a way that they would not only have to coopperate with the Office of Markets in getting up the market reports, but in many other ways. In the meantime, before these state and municipal departments are established, the Office of Markets should be given the power and funds to furnish the best market-reporting services it can devise. With the help of county demonstrators and by the addition of a few more representatives in the wholesale markets, it can furnish complete market information from day to day for the principal perishables. At present it could use the state agricultural colleges as the main state offices for the gathering and dissemination of the information.

\section{Regulation of Transportation, Refrigeration, and Terminal Facilities}

The Interstate Commerce Commission and the different state railway commissions now have regulative power over the refrigerated and ventilated car service as well as over rates and other services furnished by transportation companies. This control should stay in the hands of the railway commissions, but the Office of Markets and state departments of markets should be given the power to represent before the railway commissions all shippers who have complaints 
against the railroads in regard to the shipment of perishables or other agricultural products. Then, all a shipper would have to do if he thought that a railroad had treated him unfairly in regard to car service, rates, damages for exposing the goods, etc., would be to turn his case over to the market department. If, after investigation, this department found that the shipper had a just complaint it would, without cost to the shipper, represent him before the railroad commission, or in the courts, if the case went that far. At the present time the small shippers find it too much trouble and too expensive to carry their cases against the railroads to the railway commissions, whereas under the above plan all they would have to do would be to turn the matter over to the local representative of the market department or Office of Markets. This plan would cause the railroads to be more careful in handling this class of goods and to treat the shippers with greater consideration.

All individuals and companies furnishing commercial storage or refrigeration should be licensed by the state department of markets and should have their business practices regulated just as the business of the commission man should be regulated. They should be subject to frequent inspection by the officials of the department of markets, and should furnish regular reports of amounts of goods in their care, rates charged, etc. In this way the storage and refrigeration business could be standardized and fair treatment insured to all.

We have already pointed out that perishables are greatly exposed after they reach our wholesale markets because of inadequate and decentralized terminal and wholesale market facilities. Municipal market departments could be of great service if they were given the powers to force the railroads to furnish better and more centralized terminal facilities for these goods and to establish municipal wholesale market buildings in connection with these railroad terminals. 
All the railroads entering each wholesale market should be compelled to come together and furnish one central terminal (possibly two or three for New York City) for unloading all the perishables which enter those markets. These terminals should be equipped with large refrigerated sheds into which the cars should be run for unloading. In connection with them the cities should build modern wholesale market buildings on plans similar to those of the wholesale market buildings of Paris, Berlin and other European cities. ${ }^{1}$ Where such a market building is constructed all the wholesale dealers in the city should be compelled to transact their business in it, and the renting of the quarters and the regulation of the building should be in the hands of the municipal market department. There is little doubt that in many of our large cities wholesale market buildings will not be constructed for a long time to come-they can come only after a campaign of education. But even now the railroads should be forced to furnish centralized terminal facilities around which the wholesale trade would grow up, instead of being scattered all over the city as it is in most cases. Such centralization of the wholesale market within a small area near the terminal would eliminate the present undue exposure of the goods and expense in carting and re-carting the goods over and across the city.

\section{E. Investigative and Educational Work}

The Office of Markets, since its organization in 1913, has devoted its whole time to investigative and educational work. In fact, the law which created this office limits its work to this field. On this point Mr. Charles J. Brand, the Chief of the Office, says:

The authority conferred by Congress in appropriating funds

1 Amer. Acad. of Pol. and Soc. Sci., vol. 1, pp. 153-165. 
for the maintenance of this Office provides for the collection and distribution of useful information on subjects relating to the marketing and distribution of farm products, and the study of coöperation among farmers in the United States. So far as marketing work is concerned, the activities of the Office, therefore, are limited to the collection and distribution of information. For example, it has no authority in cases of alleged dishonesty on the part of producers, carriers, dealers, or buyers. ${ }^{1}$

According to Mr. Brand's report, the Office of Markets is now working on the following problems in regard to marketing perishables: ( I) A study of coöperative purchasing and marketing-investigation of the methods of the successful associations. (2) Marketing business practices-the essentials in the conduct of the business, as competent management, accurate records and accounts, proper equipment, etc. (3) Market surveys-supply and demand in different markets, advisability of news service and the cost of same. (4) Market grades and standards-study of the present methods of grading and packing-investigations to determine the advisability of national standardization of grades, weights, measures and packages or containers-lack of uniformity of state laws in this respect. (5) City markets and distribution-commercial methods of distribution in the city -advisability of municipally owned wholesale and retail markets. (6) Transportation and storage-how best to render assistance to individual shippers and to associations - terminal and transfer facilities-transit and other privileges - car supply - freight rates - minimum car-load weights - commercial storage, etc. (7) Marketing by parcel-post and express-experiments in these methods.

Because of inadequate appropriations much of the work

${ }^{1}$ Report of the Chief of the Office of Markets, July 31, 1915. 
outlined by Mr. Brand has not been pushed to a very great extent. But the office has done excellent work in investigating many of the special questions connected with the marketing problem. It has issued several bulletins on the bases of these investigations, some of which have been referred to in this work, and other bulletins are now being prepared for issue. All this information will be of great aid to both shippers and wholesale men and may result in decreasing the total costs of marketing. We can not hope to make much progress in improving the marketing system until we get the detailed facts in regard to each problem.

It has been the practice of the office in carrying on its work to send experts out in the field to give advice to shippers and coöperative associations as to the best means of carrying on their business. These experts have been sent to the cities to study the marketing problems there and to advise with the city officials in regard to handling their marketing problems. The few state bureaus and departments which have been established to deal with the marketing problems have also rendered much advice to producers and middlemen in regard to methods and practices of marketing and their work has been of some educational value, and, probably, of some practical value. Mr. John J. Dillon, head of the New York State Department of Foods and Markets, has attracted much attention from the farmers of that state and the public in general by establishing in New York City an auction market under his department. So far the state auction market has not been a very great success, but it will probably cause some of the up-state shippers to improve their business practices in dealing with farmers.

The investigative and educational work of the Office of Markets and of the different state and local market departments, though very valuable, has serious limita- 
tions. It may result in improving some business methods and practices, and doubtless will be a potent agency in increasing the number of coöperative marketing associations and the establishment of many municipal markets. But it is only by active governmental regulation of the business of those who carry on the marketing that the commerce in the goods can be standardized and the present inefficiency and abuses eliminated.

\section{F. Getting Efficient Market Departments}

There can be, then, no question as to the advisability of having the powers of the Office of Markets increased, and of creating departments of markets in each state and city to coöperate with each other and with the national office in regulating the marketing of perishables. But to get such government agencies is not an easy task.

The Mayor's Food Commission of New York City, of which Mr. George W. Perkins was chairman, submitted to the legislature of that state a bill for the creation of a state department of markets with powers and appropriations equal to those of other departments of the state government, but the bill failed largely because the wholesale men in New York City were opposed to it. ${ }^{1}$ They defeated the bill because they did not want any interference with their business,- - just as the railroads did not want the Interstate Commerce Commission to interfere with theirs. In most states we will find the same kind of opposition on the part of the middlemen, and, at the same time, there is no strong public opinion in favor of such departments because people generally are unacquainted with the nature of the problems of marketing. Consequently, it is now easy for the middlemen to defeat such legislation. But when the public be-

1 Statement by Mr. Perkins in a speech made before the Men's Association of the Brick Church of New York City. 
comes convinced that such departments are needed this opposition will no longer be effective.

Even if the Office of Markets were given regulative authority and each state and each municipality should establish a department of markets with adequate powers, such laws would not ordinarily be uniform in the different states and there would be no coopperation between the national, state, and local departments. About the only way to attain the desired uniformity and coopperation would be to have the bills providing for such legislation drawn by a national organization or association which would fight for their adoption by the national government and by all the states and cities. It would be well if we had a national marketing commission, composed of men well acquainted with the marketing problem, to draw bills defining the powers and duties of the Office of Markets and state and municipal departments of markets. ${ }^{1}$ After these bills are presented, if the conference of governors should adopt a resolution in favor of departments of markets with uniform powers for all the states, there would be a fair chance of getting such legislation.

If it is not possible to create a national marketing commission, some national private organization, like the $\mathrm{Na}$ tional Chamber of Commerce or the Southern Commercial

${ }^{1}$ Mr. David Lubin, Delegate of the United States to the International Institute of Agriculture at Rome, has recommended to Congress the creation of a National Marketing Commission. A copy of the bill, together with Mr. Lubin's speech in support of it, are to be found in Hearings before the Committee on Agriculture, House of Representatives, 63rd Congress, Ist, 2nd and 3rd Sessions, Vol. II., pp. I3II1326. It will be noted that this National Marketing Commission was to be a permanent one and was to have many duties other than investigating marketing problems and recommending legislation. Such a national commission is not advocated in this chapter, but one similar to our American Commission on Rural Credits-one to study the problem and recommend uniform legislation. 
Congress, should take up the question and formulate uniform legislation to be submitted to the various law-making bodies.

II. REDUCTION OF THE COSTS THROUGH COÖPERATIVE

\section{ASSOCIATIONS}

It is not our aim, here, to enter into a detailed discussion of the principles upon which coöperative associations rest. There have been several volumes written on this subject, and the Office of Markets has recently published several bulletins explaining the coöperative principles and how to run coöperative associations successfully. However, it would not be out of place for us to discuss briefly the fundamental advantages and disadvantages of farmers' cooperative marketing associations.

The principal advantages claimed for these associations over private shippers-that is, the advantages to the farmers and to the trade-are: (I) Improvement in standards and grades; (2) more constant prices to farmers for their products; (3) reduction of the waste of competition and the elimination of unfair practices at the shipping point; and (4) the elimination of profits made by private shippers.

(I) An efficient manager of a marketing association would educate the farmer-members as to the best quality and variety of goods to produce, and, on the whole, he would help them to turn over to the market a superior product. The association would adopt standard packages and grades for all the goods it ships (with its own trade-mark stamped on them) and, if it allowed the farmer-members to grade their own products, they would have standards to go by-but such associations have found that the grading must be done by the employees of the association in order to insure honest and efficient grading. This would be a much better situation than where several different private 
shippers have their own grades and standards and do not encourage the farmers to produce better products. However, as we have pointed out, if the grades and standards are to become uniform for the trade as a whole they must be formulated and enforced by government agencies.

(2) Each coöperative association could "pool " its sales for each week or month and pay all the members the same prices for the same grade of goods. This would eliminate the disadvantage of the daily fluctuations in the prices of each shipment in the wholesale markets, or would insure each farmer a fair average price for each lot of produce he turns over to the association: whereas, if he sells to private shippers, he is paid according to the market conditions at that particular time.

(3) The cooperative association, of course, would eliminate unfair treatment of the farmers by the private shipper; such as misrepresenting the state of the market, or the grade of the goods, and in getting a monopoly of the shipping business in his community. Such an association would also eliminate the useless competition between small shippers and, if it had the support of all the farmers in the community with goods to sell, it would drive the private shipper from business altogether. If not supported by all. the coopperative association would have to compete with the private shipper. But if it were large and were managed efficiently such competition might not be detrimental to it.

(4) The one point in regard to coopperative associations of all kinds that has been made more of than any other is that they are run solely for the benefit of those who do business with them and not for profit for those who furnish the capital or run the association. The services are rendered at exactly what it costs to perform the work and there are no profits for any one. The object of the marketing association is to enable those who do business through 
it to get a higher price for their goods. When an association is efficiently run and can market the goods at a less cost than could the supplanted shippers, there is no doubt that the no-profit feature of the organization is of great value to the sellers. Even in a case where the association can not perform the work as cheaply as the private agency, but is enabled to pay the farmers a higher price because it takes no profits while the private agency took large profits, the organization is of value to the farmers.

The main difficulties and disadvantages which confront coöperative marketing associations are: (I) unwillingness of farmers to submit to coöperative principles; (2) inefficient management; (3) seasonal character of the business; and (4) unfair competitive methods of private middlemen.

(I) It is claimed that one of the principal causes for the frequent failures of coopperative associations in this country has been the failure on the part of the coopperators actively to accept the true principles of coöperation. The " one man one vote" principle has never proved popular, but where cooperative associations have been organized on the principle of " one share one vote" the control of the policies of the organization has generally gone to a few stockholders and many of the original coöperators have lost both control and interest in the business-in short, the coöperative associations have been converted into corporations run, like all other corporations, for the benefit of the few stockholders. Many of those who have had money to invest have been averse to putting it into coöperative associations where the return is to be only nominal in case the business succeeds, and nothing in case it fails-in fact, the non-profit feature of coöperation has been popular with those who have had little or no money to invest. So, in most cases, it has been very hard to get sufficient working capital for coöperative associations of any kind. 
(2) The cooperators in marketing associations have usually been men who were ignorant of general business principles and particularly so of the technical problems of marketing. In spite of this, however, they have either gone on the principle that they could run the business themselves or that they would be able to get a competent manager for a small salary. The result has been that in many cases one of the farmers, or one of the farmers' sons, has been put in charge of the business, only to let it fail because of bad management. Sometimes they have hired inefficient managers for a small salary with equally disastrous results. It is only in the past few years that many of the new associations have come to realize that the success of such an undertaking depends on efficient and expert management, just as does that of any other business. Even when some associations have employed expert managers they have been averse to turning over the running of the business to these managers. Where all try to determine the policies of the association there is bound to be disagreement, "lost motion" and, eventually, failure. A good deal of freedom of action must be centralized in the manager, the executive head.

(3) Not a few coöperative marketing associations have failed because the members have not remained loyal to them. Some have become dissatisfied because they felt that their neighbors were getting more good from the association than they were themselves. They have broken off because they did not like certain rules adopted by the association, or certain policies followed. The seasonal character of the business itself has been no small factor in contributing to the loss of interest in the organizations. During the harvesting and shipping season it is easy to keep up interest in the business-each farmer feels that he is getting something out of it. But between seasons the enthusiasm dies down and with 
each new season the association has to be reorganized and rejuvenated.

(4) The competition of private shippers has been, in a great many instances, the cause of the death of coopperative associations. In not a few cases this competition has been unfair. Where new associations have been organized, private shippers have raised their price-offers to the farmers to a point at which they would actually lose money on the business in order to "break" the coöperative association or to make the farmer-members desert it so that it would die for lack of business. In order to prevent this, many associations compel their members to sign contracts to give all their business to the associations-this they call enforcing loyalty. ${ }^{1}$ But many farmers object to the enforced loyalty clauses and refuse to be members of the associations.

After we consider the points for and against coöperative associations about the only clear conclusion we can arrive at is, that after an association is organized its success or failure depends on whether it is able to give the farmers a higher average price for their goods than they would get by selling to, or through private shippers. The determination of this question depends very largely upon whether the association can carry on the business as efficiently and at as small a cost as can the private shipper.

In order that a shipping agency, whether private or cooperative, may market its goods at a very low cost per unit it must possess the following characteristics and advantages: Have a large amount of goods to ship so that it can ship in car-lots and keep its capital and employees constantly at work during the shipping season; be managed by an expert manager - a man who has had experience in both the business and technical side of the undertaking; be honestly,

1 Brooks, Markets and Rural Economics, p. 129. 
as well as efficiently, managed; and have sufficient credit and circulating capital to carry on the business. As to whether farmers' coöperative shipping associations would have these characteristics and advantages to a greater degree than private agencies can not be decided upon general principles, but will depend on the peculiar circumstances surrounding each case. That is, whether coöperative associations can pay farmers larger prices for goods than can private shippers will depend on the state of the business and on social conditions which exist at that particular shipping point.

In a community where several well-to-do, intelligent farmers are producing a large amount of a particular perishable or class of perishables for the market, and where the shipping business is in the hands of several small, inefficient, competitive private shippers, the organization of a cooperative marketing association would very probably be beneficial to the farmers. Under such circumstances it probably would not be very hard to get a sufficient amount of capital subscribed, the coopperators would realize the necessity for having efficient management, and the private shippers would be too small and weak and the coöperators too intelligent for the shippers to induce the farmers to leave their association. By combining the business of the several small shippers such an association would be large enough to ship in car-lots, keep its capital and employees constantly employed, have its representatives in the wholesale markets. and get the other advantages of large-scale business which go to make up a low cost per unit of business carried on.

On the other hand, at a shipping point where the producers are small farmers who have little or no community spirit and who carry to the market a great variety of perishables. but small quantities of each one, and where the shipping business is in the hands of one or two fairly efficient private 
shippers it would be very hard to organize a successful cooperative marketing association. Here it would be difficult to get sufficient capital for an association and the coopperators would probably disagree among themselves as to policies, management, etc. The business of the association would not be large enough to get a low cost per unit and the competition of the private shippers would likely take the business away from the association and drive it to the wall.

We now have over 10,000 coöperative marketing associations in the United States, ${ }^{1}$ most of which are successful. But it is probable that two or three times that number have been organized and failed. Many new ones are being started each year, a large percentage of which have failed or will fail. However, it is probable that a smaller percentage of unsuccessful ones have been organized recently than heretofore, because the Office of Markets has done much to educate coöperators as to the best plans of organization and business methods. It has sent men into the field to study the economic and social situation in communities before advocating the organization of particular associations. In short, it is the opinion of the officials of that Office that under certain conditions coöperative associations should not be encouraged, while under others they should - they realize that an association's success depends on the surrounding conditions. In many instances it would be more economical to retain a very large percentage of the private shippers than to try to supplant them by coöperative associations.

It is not necessary to give much consideration to the possibilities of reducing the costs of marketing through cooperative stores. They are confronted with most of the

1 Office of Markets, Doc. I, p. 2. 
difficulties which face coöperative marketing associations. Our experience with them in America has been most discouraging. Few such stores have ever been organized in our cities and the experience of the Farmers' Alliance with stores in the rural South and West was disastrous to those who put their money in them. However, if they ever get established on sound business principles here as they have in England they will be a factor in reducing the costs of marketing perishables as well as of all other consumers' goods. ${ }^{1}$

\section{REDUCTION OF COSTS THROUGH COMPETITION}

\section{A. Among Shippers}

At many shipping points competition has been a factor in increasing the costs of marketing, while at others it has greatly decreased those costs. The competition between several small shippers at the same shipping point has been costly to the farmers at those places when the business of none of the shippers was large enough to make for efficiency and low costs. But where one or two shippers, by their superior business ability, have driven the small shippers out of business, these large shippers have, on the whole, reduced the costs of marketing the goods.

In California and Florida, large private fruit exchanges, which have established branch offices at various shipping points, have been able to secure a very large percentage of the shipping business. ${ }^{2}$ In fact, practically all the shipping in both California and Florida is carried on by these large private shipping agencies and the large cooperative societies, leaving only a very small amount of business for the smaller individual shippers and community

${ }^{1}$ Discussion of English Coöperative Associations, Senate Doc. 214, 63d Cong., pp. 787-790.

2 Dept. of Agri., Office of Sect., Report No. 98, pp. 268-203. 
coöperative societies. In the fruit and vegetable sections of Texas, Missouri, Georgia and other states the large private shipping agencies covering great areas with their branch offices are driving the small local shipping agencies (both coöperative and private) either out of business or into combinations. In other words, the force of competition in this field, as in manufacturing and transportation, is supplanting the small, inefficient business units by larger and more efficient ones. This movement must be guarded against. Though it brings lower costs of doing business it brings, at the same time, monopolistic dangers which will be detrimental to the trade unless the business of the shippers is regulated by the government.

\section{B. In the Wholesale Trade}

We have already noted the fact that, in many instances, car-lot shippers have taken over the work of brokers and commission men when they found it advantageous to do so. In other cases the work formerly carried on by one class of middlemen has been divided and is now carried on by two classes. The force of competition brings about these readjustments in the wholesale business and they generally mean a lowering of the costs of carrying on the business.

Though there are no statistics available to prove the point, it is a general observation of those who have studied wholesale market conditions that the aggregate number of competing wholesale men (that is, men in the same businesslike car-lot dealers, etc.) are not increasing as fast as the increase of trade in perishables. In other words, the business is being carried on by a limited number of larger and larger business units rather than by many small ones. This can be due only to either one of two facts: First, that there is a combination among wholesale dealers to keep new men from going into the wholesale business, or, second, that large 
concerns can carry on the business at less cost than can small ones. Though it is a known fact that different classes of wholesalers have at various times formed agreements among themselves in regard to business practices, still there is little or no evidence that they have ever made agreements among themselves to keep new men from entering the business. The real reason for this concentration in the business seems to be the superior business efficiency of large-scale business.

Competition among wholesalers has caused many improvements in methods of performing different operations and in taking care of the goods. The concern with the best trucking and storage facilities and the best and cheapest methods of re-grading and re-packing the goods will probably have a lower cost of doing business than its competitors. Competition for profits has been a large factor in developing the use of cold-storage, of which we shall speak in the next chapter. So, as time goes on, we may confidently expect that competition will be a material force in reducing the costs of passing perishables through the wholesale markets.

\section{Competition in the Retail Trade}

In the retail trade there may be competition between five different types of retailers, besides competition between different retailers of the same type. These different types are: hucksters, coöperative stores, municipal retail markets, chain stores and large private markets, and small grocery stores. It is not necessary for us to discuss here the hucksters and coöperative stores as we have already pointed out their usefulness and limitations. But it will be well to give a brief consideration to the competition between the other types of retailers.

The dealers in the municipal retail markets have the following advantages over the private stores in regard to costs 
of carrying on their business: They generally get low rents from the city; the dealers often combine and make their purchases in large quantities, thus getting the advantage of a low price for the goods they buy; as a rule, they do not deliver the goods they sell, but have the purchasers carry the goods home; they sell for cash and lose nothing from bad debts; they have no telephone expenses. All these advantages enable dealers in the municipal markets to sell their goods to consumers at lower prices than the corner grocer, whose expenses are much heavier. But the municipal markets have some disadvantages. They are generally a great distance from the majority of the consumers whom they hope to serve. Most American housewives have formed a habit of ordering goods over the telephone, or, in passing by the store, leaving their order to be filled and delivered. Consequently, they are unwilling to go to the trouble and expense of going to a distant municipal market to buy and bring back with them the goods they desire. Not least of all, a very large percentage of families have formed the habit of buying on credit and settling their bills weekly, monthly (or not at all), and many of them now find it either very troublesome or impossible to pay cash with each purchase.

The gist of the municipal retail market problem is, that if the consumers will take the extra trouble and expense of buying from the market they can get the goods for less than if they buy from the corner grocer. But there seems to be only one class of consumers who will, to any great extent, make the sacrifice, and they are the housewives in moderate circumstances. The rich do not consider the difference in prices great enough for the extra trouble. The very poor either do not find time to go to the market or are not able to pay cash for the goods. ${ }^{1}$ The result is that

1 Yearbook of the Dept. of Agriculture for 1914, pp. 160-172. 
a very large number of retail markets which have been established are not well patronized. Before establishing a municipal market the officials of the municipal department of markets (or other officials who have the work in charge) should study the surrounding conditions carefully and endeavor to place the market where it will be most accessible to the people who are likely to use it. There is little doubt that under certain circumstances municipal retail markets will be a great factor in reducing the costs of marketing perishables and the cost of living in general, but, unless the habits and customs of consumers undergo a radical change, the part which they will be able to play will be very much more limited than is generally supposed.

The chain-store business is growing very rapidly in most of our large American cities. In Philadelphia, which is a good example, about five per cent of the retail stores belong to the chain system, ${ }^{1}$ and they probably do about ten per cent of the retail business in groceries of all kinds. It has already been pointed out that these chain stores have great advantages in buying more directly and in large quantities. They generally sell for cash and have a very rapid rate of turn-over of their capital. Each chain of stores is managed from a central office by high-grade managers and the clerks and employees of the individual stores are the best that can be secured." On the whole, the chain-stores' cost of doing business is much less than the independent grocers', and so they can sell to consumers at a lower price. The chain store, like the independent grocer, is situated near the consumers, furnishes telephone and delivery services and so does not interfere with the habits and customs of the people (except where they sell only for cash).

${ }^{1}$ King, Lower Living Costs in Cities, p. $7 \mathrm{I}$.

2 Patterson, Annals of Amer. Acad. of Pol. and Soc. Sci., vol. 1, p. 77. 
In order to compete with the chain stores, the independent grocers in Philadelphia and other cities have organized wholesale associations of their own through which they are able to buy more directly and in larger quantities than heretofore. Other independent grocers, in order to cut down expenses of doing business, have combined on a common delivery service. This has been particularly true in some of the Western cities. So, taken as a whole, the chain stores have been a large factor in reducing the costs of retailing, and thus reducing the costs of marketing perishables. It is very probable that they will be a much larger factor in the near future than they have been already.

There are two types of large private markets. One is where a large market building is owned by private interests and the stalls are rented to retailers who specialize in handling one line of goods-as fruit sellers, vegetable dealers, etc. The Astor Market at 95th Street and Broadway, New York City, is a good example of this kind of market. Then there is a second type which is very similar to the chain store. Here an individual or a company will establish market buildings in different parts of the city. In each of these buildings there are departments for each class of food products - a fish department, a meat department, a vegetable department, etc. A good example of this type is Weisbecker's Markets in New York City. There is no special advantage in the first type of private market except that it is sanitary and that it enables the owner of the building to get a large rent for his property. The second type has all the economic advantages which the chain store possesses and is a large factor in giving the people food at a cost lower than the small grocer can give. Many of these private markets maintain no delivery service and fill no telephone orders, but require customers to come to the market just as do the municipal retail markets. But as they are smaller 
they have an advantage over the municipal market in being established nearer the homes of the customers.

There is little doubt that the great interest in scientific management which has been awakened in America, and the establishment of business schools in connection with our high schools, colleges and universities will result in the better education of retailers and of the young men who will enter the retail business. So there is good reason to expect the grocers of the future to do business on a smaller margin. 


\section{CHAPTER VI}

REDUCTION OF THE BURDENS OF MARKETING BY CHANGING THE NATURE OF THE GOODS AND AREA OF PRODUCTION

To discuss in detail how the nature and character of perishables might be changed so that the costs of marketing them would be reduced would carry us far into the fields of chemistry, plant and animal breeding and the general science of agricultural production. These are problems which belong to specialists in those fields and the writer, like most students of economics, is not competent to discuss them from their technical side. But happily, from the marketing viewpoint, it is not necessary to understand the scientific details of how these changes in the character of the goods are brought about; one only needs to know that certain changes can be accomplished and to understand the influence which they will have on the marketing problem. For example, we know that plant breeders are constantly improving the variety, vigor and area of growth of certain plants and that the possibilities of further progress along this line are not even measurable by those scientists. We know that the methods of canning and preserving certain food products are still in their infancy though the industry has developed very rapidly in recent years. How is marketing affected by these changes?

I. REDUCTION OF THE PERISHABILITY OF THE GOODS

In Chapter III it was pointed out that one of the greatest causes of the high cost of marketing perishables was the fact that the goods are subject to a very rapid rate of decay I64 
after they are harvested. How can the cost be reduced by making these goods less perishable, and what progress has already been made along this line? They can be made less perishable by the development of cold-storage facilities, by manufacturing the goods, or by producing hardier varieties.

\section{A. Cold Storage}

From the chemical viewpoint cold storage is not a method by which the nature of the goods is to be changed, but a process of preserving their natural qualities. From the marketing viewpoint, however, any change which allows goods to be kept a longer period of time than they can now be kept is a change in the character of the goods-without cold-storage facilities the goods are by nature highly perishable, whereas cold storage will put them in a class with less perishable ones. To allow a good to decay because of failure to use cold storage after the facilities are developed and are available, would be a failure to prevent preventable decay-and would be a defect in the marketing methods. But the development of new storage processes to stop decay which is now preventable under the present methods, would be a change, from the marketing viewpoint, in the character of the goods.

The commercial storage business in the United States started about I889, and to-day there are approximately I,, 00 public and private cold-storage plants in different parts of the country, representing an investment of over $\$ 75,000,000 .{ }^{1}$ Each year there is placed in these storage plants more than $\$ 102,000,000$ worth of butter and eggs alone, $^{2}$ and the total value of all goods placed in them amounts to between $\$ 500,000,000$ and $\$ 700, \infty 00,000.8$

${ }^{1}$ Horne, Annals of Amer. Acad. of Pol. and Soc. Sci., vol. 1, p. 45.

'Holmes, Annals of Amer. Acad. of Pol. and Soc. Sci., vol. 1, p. 49.

3 Horne, Annals of Amer. Acad. of Pol. and Soc. Sci., vol. 1, p. 45. 
Though it has not been the practice to place fruits and vegetables in storage on as large a scale as butter, cheese, poultry and eggs, a larger percentage of these highly-perishable goods is being placed in storage than ever before. Below is given a list of the fruits and vegetables which are commonly placed in storage each year for a longer or shorter period of time. ${ }^{1}$

$\begin{array}{llll}\text { Apples } & \text { Citrons } & \text { Lettuce } & \text { Pineapples } \\ \text { Apricots } & \text { Cherries } & \text { Limes } & \text { Plums } \\ \text { Asparagus } & \text { Cranberries } & \text { Melons } & \text { Potatoes, Irish } \\ \text { Bananas } & \text { Cucumbers } & \text { Mushrooms } & \text { Potatoes, Sweet } \\ \text { Beans } & \text { Currants } & \text { Mustard } & \text { Prunes } \\ \text { Berries } & \text { Cymblings } & \text { Onions } & \text { Radishes } \\ \text { Beets } & \text { Eggplant } & \text { Oranges } & \text { Rhubarb } \\ \text { Brussels Sprouts } & \text { Figs } & \text { Parsley } & \text { Spinach } \\ \text { Cabbages } & \text { Fruit Juices } & \text { Parsnips } & \text { Strawberries } \\ \text { Cantaloups } & \text { Grapefruit } & \text { Peaches } & \text { Tangerines } \\ \text { Carrots } & \text { Grapes } & \text { Pears } & \text { Tomatoes } \\ \text { Cauliflower } & \text { Kale } & \text { Peas } & \text { Turnips } \\ \text { Celery } & \text { Lemons } & \text { Peppers } & \text { Watermelons }\end{array}$

Practically all these perisnables are put in storage during the "flush" season when the physical supply is greater than the demand for consumption, and are taken out in the winter months when there is a shortage of fresh supply. It is estimated that, on the average, eggs are kept in storage 5.9 months; butter, 4.4 months; poultry, 2.4 months. There are no statistics as to the length of time various fruits and vegetables are kept there, but it is necessarily a shorter period than for any of the dairy and poultry products enumerated above.

Though only between five and ten per cent of the total annual production of butter, cheese, poultry and eggs, and a still smaller percentage of the fruits and vegetables, are now

${ }^{1}$ Holmes, Annals of Amer. Acad. of Pol. and Soc. Sci., vol. 1, p. 55.

'Horne, Annals of Amer. Acad. of Pol. and Soc. Sci., vol. 1, p. 47. 
placed in storage, yet the storage of this small percentage of products is a great factor in conserving periodic surpluses for future periodic scarcities. As to the value of refrigeration in conserving the goods, Mary E. Pennington, of the Bureau of Chemistry, United States Department of Agriculture, says: "It is not possible to feed our great cities without the help of these great food depositories. It is not possible to bring perishable foodstuffs to our cities, or to market them, without the help of refrigeration." I

It is claimed by the cold-storage interests that cold storage has made the prices of storage products more constant throughout the year, and, on the whole, has tended to reduce the prices of those goods to consumers. ${ }^{2}$ But in his investigation of the relation of cold storage to prices, Mr. George K. Holmes. Chief of Division of Production and Distribution, United States Department of Agriculture. says this is true only for certain cold-storage products, whereas there are higher prices and greater fluctuations for others. $^{3}$ There is no question that as cold-storage methods improve and the cost of performing the work is lessened through more modern and larger plants refrigeration will tend to steady the daily and monthly prices to both producers and consumers and, beyond a doubt, will reduce the costs of marketing such goods. As to whether it will lower the price to the consumer or raise it to the producer will depend wholly on who gets the advantage of the reduced cost of marketing. Again, there can be little question of the great advantage of cold storage to the public health, in spite of the dislike of the average consumer for cold-storage products."

1 Report of the Market Com. of the Mayor of New York City, p. 137.

${ }^{2}$ Horne, Annals of Amer. Acad. of Pol. and Soc. Sci., vol. 1, p. 46.

3 Bul. No. 10I, Bureau of Statistics, U. S. Dept. of Agri., pp. 68-69.

4 Pennington. Report of the Mayor's Market Commission of New York City, p. 136 . 


\section{B. Manufacturing}

The possibilities of making perishables less perishable by passing them through various manufacturing processes are very great. Some perishables may be made into beverages, as grapes into wine or apples into cider; from all fruits various conserves may be manufactured; and practically all perishables may be canned so as to retain in some measure their original flavor and use.

It is not possible to say just what percentage of the fruits in this country are consumed by the manufacturers of alcoholic and non-alcoholic beverages, but in many sections the percentage is very great. Much of our "imported" champagne and wine are made from California fruits. A large percentage of the grape growers of Western New 'York and other lake districts find a ready market for their product at the grape-juice factories. The apple growers of many sections produce apples for the manufacturers of apple cider and vinegar. Just recently many cider mills have been established to manufacture the surplus supply of apples. Owing to the prohibition laws of the various states there has been a decrease in the consumption of alcoholic liquors in the United States in the past two years, so that the demand for perishables for this purpose will probably decrease. On the other hand, it is probable that the demand for non-alcoholic beverages will considerably increase and lead to corresponding increase in the demand for the raw products.

There has been a very considerable increase in the canning and preserving industries in recent years in the United States. The following table will give an idea of this increase : ${ }^{1}$

${ }^{1}$ Statistical Abstract of the U. S., I9I3, p. 186. 
Number of Value of

Establishments. Raw Material.

$1909 \ldots \ldots \ldots \ldots . . \ldots, 767$

$1904 \ldots \ldots \ldots \ldots . \ldots, 3,168$

I $899 \ldots \ldots \ldots \ldots \ldots 2,570$
$\$ 101,823,000$

$83,147,000$

$63,668,000$
Value of Finished Products. $\$ 157$, IOI,, 000 I $30,466,000$ $99,335,000$

If statistics for a more recent date were available they would undoubtedly show that this industry has grown faster since Igog than it did in the same length of time prior to that date. It is also quite likely that this table does not include a great number of small, private, unincorporated canning and preserving plants.

This industry takes, as its raw materials, practically every kind of perishable, but some in very much larger proportions than others. Between five and ten per cent of all perishables are sold to this industry, while for tomatoes, peas and beans, peaches and other fruits and vegetables the percentage is very much larger. As a whole, this industry is in its infancy in the United States. In fact we have been importing a very large percentage of the condiments, jellies and preserves we use instead of making them from the products which we have allowed to go to waste. ${ }^{1}$ There is little doubt that this industry will consume a rapidly increasing proportion of our perishables in the future.

This industry will take the surplus goods off the market in the flush season and convert them into products which can be used, in the seasons of scarcity, as food substitutes for the fresh goods. So, as it develops to much larger proportions, it will be of an incalculable force in lessening the wastes from decay and in reducing the costs of marketing the fresh products:

\section{Producing Hardier Varieties}

Burbank, the United States Department of Agriculture - ${ }^{1}$ See statistics of imports in the United States. 
and other individuals and associations specializing in animal and plant breeding have already done much, not only in giving us better-flavored goods and a greater variety, but also in giving us products which are less perishable. The California fruit growers have continually experimented with their products until they have gotten varieties which will stand shipment across the continent or even to foreign countries. The possibilities along this line are very great, and there is no doubt that in the future many products which are now highly perishable will come to be regarded as staples. Such a change will dispel many of our most perplexing problems in regard to marketing these goods.

II. REDUCTION OF SEASONAL PRODUCTION

\section{A. Development of Varieties which have a Long Season of Harvesting}

The plant and animal breeders have already done, and are cloing, much to give us varieties of fruits, vegetables, chickens, cows, ctc., which have a more constant production, or produce during a longer period of time. The peach season in most sections of the South now runs from June to October or November, while some years ago it only lasted for a few weeks. Similar improvements have been made in other fruits and in many vegetables. We now have breeds of chickens which lay almost constantly, both winter and summer, and cows which give almost as much milk in winter as in summer. Such improvements are partly due to the fact that the farmers know better how to care for and cultivate the plants and animals than formerly, but they are largely due to the progress which has been made in producing improved varieties.

Further progress along this line (which is sure to come) will do much to reduce seasonal variations in supply and 
will thus reduce the cost of marketing the goods. It will also give consumers a more plentiful supply of fresh goods in what is now the short season.

B. Widening the Area of Production for Different Goods

Of no less significance is the extension of the area of production for different fruits and vegetables. The extension of the area of production of corn, of peas, and of cotton are familiar to all of us, but some of us do not realize that many fruits and vegetables of high perishability have had their area of production equally extended. Strawberries are now produced in almost every section of the United States, peaches, cabbage, watermelons and grapes are also to be found in most sections. The area of production of citrus fruits (oranges, lemons and grapefruit) has been extended so that Texas is becoming a large producing section along with California and Florida. All this has been made possible by the plant breeders who have produced varieties which will thrive in the new areas.

Such progress will have two very marked effects on the marketing problem. It will give a more constant yearly supply of each product for the general market. That is, we will not be wholly dependent on the success of the California crop for our oranges, or on Georgia for our peaches. The wider the area of production the more constant will be the national supply. It will also tend to reduce the average distance which some goods now have to be shipped to market, because it will enable each consuming center to draw a larger percentage of its supply from the immediately surrounding territory.

\section{DEVELOPMENT OF CENTRALIZED PRODUCING SECTIONS}

If the sections of each county and state which are best suited for the production of particular perishables would 
specialize in producing those goods in large quantities the marketing situation would be greatly simplified and the costs reduced. That is, if the vegetable production for market were centralized at fewer shipping points the goods would be gotten to the market at a lower cost. This does not conflict with the extension of the area of production for different goods. Extension of area means producing the goods in a greater number of states or large areas of the country. Concentrating the production in a state (or any other territorial area) means producing the goods at, or near, a smaller number of shipping points-that is, having a few communities in that state to produce that specific good for the market.

This community specialization in production has many advantages from the production side, but we shall discuss them only in so far as they relate to marketing. From the marketing side it has the following advantages: A common interest in the same products will cause the farmers to produce those which are best suited for marketing purposes. There will be enough of such products to be shipped from one shipping point so that they can be sent to the market in car-lots. The business will be big enough to have the best type of shipping agencies (whether private or coöperative)-agencies which will have facilities for taking care of the goods, agencies which will know how to keep in touch with the best markets, how to grade, pack and ship the goods. In short, the cost of getting the goods to marliet will be less and the prices the farmers will receive will be greater in these specialized communities than in the communities where the producers of the same goods are few and scattered.

The communities for specialization in production of a particular product or class of products should be selected with reference to several factors. They should have the 
best transportation facilities to be obtained; that is, they should be accessible to the principal markets for shipment of goods. They should be in sections where the climate and soil are best suited for the production of the goods. They should be in sections where the land values are not inflated or very high because of the possibilities of being used for industrial or commercial purposes-that is, the values of the land should be fixed solely by its agricultural productivity.

Because of the above requirements for perishable-producing sections the territories immediately surrounding the large cities and towns are not now very large producing sections, and are not likely to become so in the future. The suburban territory has the advantage of being very close to one market and fairly accessible to others. But when we remember that the cost of transportation (even including the losses from decay) is not very great per unit of product (if shipped in car-lots) even for long distances, it is easy to see that this factor might be outweighed by several disadvantages which the suburban territory might have. Unfortunately, much of the suburban land near our large Eastern cities, because of the nature of the soil and climate, is not well suited to the production of many perishables. Long Island, near New York City, is an exception to this rule, but Mr. George Perkins estimates that, even with this, the suburban farms of New York City do not produce enough perishables the whole year to feed the city three days.

Again, practically all the land surrounding all large towns and cities is too high in value for miles out to permit its being used on a large scale for truck, dairy and poultry farming. A large part of it is held by land speculators or by the rich who own country estates. neither of which classes cares to engage in farming for commercial purposes. Any land which a truck farmer might be able to get would 
have such high rental charges and his cost of production would be so high that he would find it difficult to compete with the farmers in rural sections many hundred miles away.

However, the suburban farms do, in spite of the disadvantages of their nearness, produce a large percentage of certain perishables which are consumed in the nearby city. Most of the milk supply in the very large cities is produced within a radius of from one to two hundred miles, and for the small cities the radius of supply is much less. Then a large part of the poultry products for the medium-sized towns are produced on the suburban farms. But the suburban territory supplies a very small percentage of the fruits and vegetables, except to the country towns. These are goods which require more land space, are more variable in supply and need a wider market than one town.

The great producing communities of most perishables will, in the future, likely be far away from the cities. They will be in rural sections which are eminently suited for such production because of the superiority of their soil and climate and because their land values are regulated solely by agricultural considerations. 


\section{APPENDIX A}

\section{The National Law for the Standardization of Apple Grades and Containers}

(Commonly called "The Sulzer Apple Law.")

Be it enacted by the Senate and House of Representatives of the United States of America in Congress assembled, That the standard barrel for apples shall be of the following dimensions when measured without distention of its parts: Length of stave, twenty-eight and one-half inches; diameter of head, seventeen and one-eighth inches; distance between heads, twenty-six inches; circumference of bulge, sixty-four inches outside measurements, representing as nearly as possible seven thousand and fifty-six cubic inches: Provided, That steel barrels containing the interior dimensions provided for in this section shall be construed as a compliance therewith.

Sec. 2. That the standard grades for apples when packed in barrels which shall be shipped or delivered for shipment in interstate or foreign commerce, or which shall be sold or offered for sale within the District of Columbia or the Territories of the United States shall be as follows: Apples of one variety, which are well-grown specimens, hand picked, of good color for the variety, normal shape, practically free from insect and fungous injury, bruises, and other defects, except such as are necessarily caused in the operation of packing, or apples of one variety which are not more than ten per centum below the foregoing specifications shall be "Standard grade minimum size two and one-half inches," if the minimum size of the apples is two and one-half inches in transverse diameter; or "Standard grade minimum size two inches," if the minimum size of the apples is two inches in transverse diameter. 
Sec. 3. That the barrels in which apples are packed in accordance with the provision of this act may be branded in accordance with section two of this act.

Sec. 4. That all barrels packed with apples shall be deemed to be below standard if the barrel bears any statement, design, or device indicating that the barrel is a standard barrel of apples, as herein defined, and the capacity of the barrel is less than the capacity prescribed by section one of this act, unless the barrel shall be plainly marked on end and side with words or figures showing the fractional relations which the actual capacity of the barrel bears to the capacity prescribed by section one of this act. The marking required by this paragraph shall be in block letters of size not less than seventy-two point one-inch gothic.

Sec. 5. That barrels packed with apples shall be deemed to be misbranded within the meaning of this act-

First. If the barrel bears any statement, design, or device indicating that the apples contained therein are "Standard" grade and the apples when packed do not conform to the requirements prescribed by section two of this act.

Second. If the barrel bears any statement, design, or device indicating that the apples contained therein are "Standard" grade and the barrel fails to bear also a statement of the name of the variety, the name of the locality where grown, and the name of the packer or the person by whose authority the apples were packed and the barrel marked.

Sec. 6. That any person, firm, or corporation, or association who shall knowingly pack or cause to be packed apples in barrels or who shall knowingly sell or offer for sale such barrels in violation of the provisions of this act shall be liable to a penalty of one dollar and costs for each such barrel so sold or offered for sale, to be recovered at the suit of the United States in any court of the United States having jurisdiction.

Sec. 7. That this act shall be in force and effect from and after the first day of July, nineteen hundred and thirteen.

Approved August 3, I9I2. 


\section{APPENDIX B}

United States Department of Agriculture

OFFICE OF MARKETS AND RURAL ORGANIZATION

WASHINGTON, D. C.

Sept. 17,1915

Peach Movement

Cars of peaches shipped yesterday were reported destined as follows:

\begin{tabular}{|c|c|c|c|c|c|c|c|c|c|c|c|c|}
\hline \multirow{2}{*}{ TO } & \multicolumn{11}{|c|}{ FROM } & \multirow[b]{2}{*}{ Tota } \\
\hline & Conn. & N. J. & Penn. & Md. ${ }^{3}$ & Mich. & N. Y.2 & Ohio & W. Va." & Colo. & Wash. & Utah & \\
\hline 2T.8 & & & & & & & & & & & & \\
\hline $\begin{array}{l}\text { Boston ......... } \\
\text { Albany ........ }\end{array}$ & $\begin{array}{l}15 \\
\ldots\end{array}$ & $\cdots$ & $\cdots$ & $\cdots$ & $\cdots$ & $\begin{array}{l}4 \\
5\end{array}$ & $\cdots$ & $\cdots \cdots$ & $\cdots$ & $\cdots$ & $\cdots$ & $\begin{array}{r}19 \\
5\end{array}$ \\
\hline New York..... & 6 & 9 & 3 & 4 & $\ldots$ & $2 \mathbf{1}$ & $\ldots$ & 10 & $\ldots$ & $\ldots$ & $\ldots$ & 53 \\
\hline Newark....... & $\ldots$ & I & I & $\ldots$ & $\ldots$ & $\cdots$ & $\ldots$ & $\ldots \ldots$ & $\ldots$ & $\cdots$ & $\ldots$ & 2 \\
\hline Philadelphia... & ... & $\cdots$ & 6 & $\cdots$ & .... & 13 & $\ldots$ & 3 & $\ldots$ & $\ldots$ & $\ldots$ & 22 \\
\hline Baltimore...... & .... & $\ldots$ & 4 & IO & $\ldots$ & 2 & $\ldots$ & ...... & $\ldots$ & $\ldots$ & $\ldots$ & 16 \\
\hline Potomac Yards. & $\cdots$ & $\cdots$ & $\cdots$ & $\mathbf{I}$ & $\ldots$ & $\cdots$ & $\cdots$ & $\cdots \cdots$ & $\ldots$ & $\cdots$ & $\ldots$ & I \\
\hline Pittsburgh ..... & $\ldots$ & $\ldots$ & $\ldots$ & I & $\ldots$ & 19 & $\ldots$ & I & $\ldots$ & ... & $\ldots$ & $2 I$ \\
\hline Buffalo......... & $\cdots$ & $\cdots$ & $\cdots$ & $\cdots$ & $\cdots$ & I & $\cdots$ & ....... & $\ldots$ & $\cdots$ & $\ldots$ & I \\
\hline Cincinnati ..... & $\cdots$ & $\cdots$ & $\cdots$ & $\cdots$ & 6 & 4 & $\cdots$ & I & $\ldots$ & $\cdots$ & $\cdots$ & II \\
\hline Columbus ..... & $\cdots \cdot$ & $\cdots \cdot$ & $\cdots \cdot$ & $\cdots \cdot$ & 1 & $\cdots \cdot$ & 2 & $\cdots \cdots$ & $\cdots$ & $\cdots \cdot$ & $\cdots$ & 3 \\
\hline Cleveland ..... & $\cdots \cdot$ & $\cdots \cdot$ & $\cdots \cdot$ & $\cdots$ & 1 & $\cdots \cdot$ & 21 & $\ldots \ldots$ & $\ldots$ & $\cdots$ & $\cdots$ & 22 \\
\hline Detroit ......... & $\cdots$ & $\cdots$ & $\cdots$ & $\cdots$ & 5 & $\cdots$ & 15 & ...... & $\ldots$ & $\cdots$ & $\cdots$ & 20 \\
\hline Indianapolis ... & $\cdots$ & $\cdots \cdot$ & $\cdots$ & $\cdots$ & 17 & 2 & 2 & ...... & $\cdots$ & $\cdots$ & $\ldots$ & 21 \\
\hline Chicago........ & $\cdots$ & $\cdots$ & $\cdots$ & $\ldots$ & 25 & $\ldots$ & $\ldots$ & $\ldots \ldots$ & 5 & $\ldots$ & $\mathbf{I}$ & $3 x$ \\
\hline Milwaukee..... & $\cdots$ & $\cdots$ & $\cdots$ & $\cdots$ & $\mathbf{I}$ & 2 & $\cdots$ & $\cdots \cdots$ & $\ldots$ & $\ldots$ & $\ldots$ & 3 \\
\hline Minneapolis ... & $\cdots$ & $\cdots$ & $\cdots \cdot$ & $\cdots \cdot$ & $\cdots$ & $\cdots$ & $\cdots$ & $\cdots \cdots \cdot$ & $\cdots$ & $\cdots \cdot$ & $\mathbf{I}$ & I \\
\hline Sioux City ..... & $\cdots$ & $\cdots \cdot$ & $\cdots$ & $\cdots$ & $\cdots$ & $\cdots$ & $\cdots$ & ....... & $\cdots$ & I & $\cdots$ & I \\
\hline Kansas City ... & $\cdots$ & $\cdots$ & $\cdots \cdot$ & $\ldots$ & $\ldots$ & $\cdots$ & $\cdots$ & $\ldots \ldots$ & $\ldots$ & $\ldots$. & I & I \\
\hline St. Louis ...... & $\cdots$ & $\cdots$ & $\cdots$ & $\cdots$ & 4 & 2 & $\cdots$ & ...... & $\ldots$ & $\cdots$ & $\ldots$ & 6 \\
\hline Omaha ......... & $\cdots$ & $\cdots \cdot$ & $\because \cdots$ & $\cdots$ & $\cdots$ & $\cdots$ & $\cdots$ & $\cdots \cdots$ & 5 & $\cdots \cdot$ & 6 & II \\
\hline Denver......... & $\cdots$ & $\cdots$ & $\ddot{m}$ & $\cdots \cdot$ & $\ddot{g}$ & $\cdots$ & $\cdots$ & $\cdots \cdots$ & & $\cdots$ & 6 & 7 \\
\hline Various ....... & $3^{1}$ & 4 & & 3 & 83 & 104 & 47 & 32 & $\cdots$ & 3 & $\cdots$ & 323 \\
\hline Total ........ & 52 & 14 & 30 & 19 & 143 & I 77 & 87 & 49 & II & 4 & $I_{5}$ & 601 \\
\hline
\end{tabular}

IIncludes 2 cars shipped by express.

Includes I car shipped by express.

Includes 9 cars shipped by express. 
Note: The above includes the following shipments reported passed Green River, Pueblo and Denver; Green River-Utah 14; Washington I. Pueblo-Colorado 3; Utah r. Denver -Colorado 8.

Shipped Wednesday not previously reported; Ohio 8, destined 2 Cleveland, 6 various; Pennsylvania I various, shipped by express.

Potomac Yards Reports 3 cars moving south.

The telegraphic report relative to conditions in the markets released to-day was based on the following:

New York, N Y., Sept. I7. 'Warm, clear; peaches, two Marylands, two Pennsylvania, six Connecticut; twenty-six New York, five West Virginia, West Marylands, eleven thousand, nine hundred Delawares, Marylands, Jerseys, New York yellows, whites, baskets twenty five-fifty; some sales ten-fifteen; carriers seventy five-dollar quarter, half bushels thirty-forty; bushels sixty-dollar; quality, demand fair.

Chicago, Ill., Sept. I7. Peaches twenty-nine arrivals, heavy receipts from Michigan by boat; bushels dollar half-sixty for best; some down to twenty; sixes half-sixty five, few fancy higher; fifths seven to fifteen; Colorado boxes sixty-sixty five; Utah fifty-fifty five; market oversupplied; demand slow and weak.

St. Louis, Mo., Sept. I7. Elbertas; one Michigans; bushels seventy-eighty; slack; condition medium; two Michigans jobbing dollar; quality good; one Colorado, same; cleaning half car Utahs dollar dollar-quarter; locals, various baskets twentythirty five; Elbertas seventy five; one late arrival Michigans Engels bushels eighty.

Denver, Colo., Sept. I7. Ten cars Utah bushel peaches one dollar.

Columbus, O., Sept. I7. Peaches, three Ohio; bushel double A ninety-dollar ten; smaller grades and over ripe forty-eighty; quality good; demand fair; cloudy, warm. 
Miluaukee, Wis., Sept. 17. Four peaches Michigan, one Indiana; Michigan bushels sixty five-eighty five; Michigan boxes serenty five-dollar; Michigan fifths ten-twelve; Washington boxes sixty-sixty five; Colorado boxes fifty-sixty; quality fair, good; demand light; clear, warm.

Boston, Mass., Sept. I7. Weather, hot, clear; peaches, three cars, two trains late; Connecticuts yellows thirty-sixty; bushels ninety-dollar; demand; quality, fair.

Albany, N.Y., Sept. I7. Two peaches; one IVestern New York, one New Jersey; bushels quarter-half; halves sixty five-seventy five; clear, warm; quality, demand good.

Cleveland, O., Sept. I\%. Peaches; twenty six Ohios; bushel half-sixty; oversupply; overripe; rain.

St. Paul, Minn., Sept. I7. Five Mixed cars peaches fifty; weather, fine.

Baltimore, Md., Sept. I7. Peaches, West Virginia half car express, Maryland three express, seven freight; Pennsylvania four; baskets twenty-forty; bushels forty-sixty five; carriers forty-seventy five; extra fancy eighty-ninety; demand fair, hot.

Omaha, Nebr., Sept. I7. Peaches, Colorado four, California two, Utah one; boxes fifty-sixty; bushels seventy five-dollar; quality good, market fair; clear, warm.

Philadelphia, Pa., Sept. I7. Receipts peaches heavy; baskets fifteen to thirty five; bushels forty to seventy.

Buffalo, N.Y., Sept. I7. Peaches New Yorks equal seventeen car; Niagara Crawfords, Elbertas thirds hampers best fifteen-quarter; bushels forty-seventy five; oversupplied; demand poor; warm, rain.

Kansas City, Mo., Sept. I7. Six arrivals Western boxes fifty five-sixty five; Colorado-Utah bushels jobbing eighty-dollar five; fair to good slow.

Buffalo, N. Y., Sept. I7. Peaches: New Yorks equal seventeen cars; Niagara Crawfords, Elbertas thirds hampers fifteentwenty five for best; bushels forty-seventy five; oversupplied; demand poor; warm, raining.

Minneapolis, Minn., Sept. I7. Peaches: one Utah, one Colorado, four Washington; box sixty-sixty five; quality fair; demand slow; weather clear, warm. 
Sioux City, Ia., Sept. I7. Peaches: one Utah; Washington and Colorado boxes sixty five-seventy; quality good, demand fair ; clear, warm.

Pittsburgh, Pa., Sept. I7. Peaches: nine arrivals; York state Elbertas double A's eighty five-ninety; A's sixty fiveseventy; Crawfords Reeves double A's sixty five-eighty five; overripe soft fruit not moving; weather cloudy, slightly cooler.

Detroit, Mich., Sept. I7. Peaches: Ohio four, Michigan one, New York two, Ohios forty five hundred; bushels half seventy five-dollar; extra fancy dollar quarter; market loaded; warm, bright.

Des Moines, Ia., Sept. I7. No arrivals; Colorado Utah Elbertas dollar; extras dollar fifteen-quarter; Western boxes fifty-sixty five; quality medium, demand good; fair, warm. 


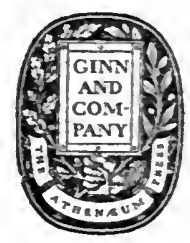

\title{
Readings on the Relation of Government to Property and Industry
}

\author{
Edited by SAMUEL. P. ORTH, Cornell University. 664 pages, $\$ 2.25$
}

This is a timely book on a topic of the most vital concern to-day. Many of the important writings on the subject are frequently referred to, yet heretofore the student has been compelled to search the files of the law reviews, the publications of the learned societies, and government documents.

\section{Selected Readings in Rural Economics}

Compiled by THOMAS NIXON CARVER, Harvard University. 947 pages, $\$ 2,80$

Excellent material ordinarily uifficult of access, and representing the authorship of many leading authorities on the subject. Agricultural History, Land Tenure, The Farmer's Business, Agrarian ilovements, Rural Organization and Marketung, and Agricultural Policy are among the subjects discussed at length.

\section{Trusts, Pools and Corporations}

Edited by WILLIAM Z. RIPLEY, Harrard University. 872 pages, \$2.75

About 400 pages of new material have been added to the Revised Edition of this well-known book. Among the recent cases discussed are the National Cash Register Case; the Steel Corporation Case of June, 1915; and the Keystone Watch Decision.

\section{The Hague Arbitration Cases}

\section{BJ GEORGE GRAFTON WILSON, Harvard University. 525 pages, $\$ 3.50$}

The first book to supply the essential material, hitherto so frequently in demand, yet difficult to find, on the work of the Hague Court since its establishment in 1899 .

\section{The Growth of American State Constitutions}

By JAMES QUAYLE DEALEY, Brown University. 308 pages, $\$ 1.40$

Part I traces the history of our state constitutions. Part II discusses the provisions of the constitutions now in force. Part III suggests the probable trend of future constitutional changes.

\section{GINN AND COMPANY}

Boston New York Chicago London




\section{Studies in History, Economics and Public Law}

edited by the

\section{Faculty of Political Science of Columbia University}

VOLOMEE I, 1891-92. 2nd Ed., 1897. 396 pp. Price, cloth, $\$ 3.50$.

1. The Divorce Problem. A study in Statistics.

By Walter F. Wizlcox, Ph.D. Price, 75 cents.

2. The Fistory of Tariff Administration in the United States, from Colonial Times to the McKiniey Administrative Bill.

By John Dran Goss, Ph.D. Price, \$r.oo.

3. History of Manicipal Land Ownership on Manhattan Island.

4. Financial History of Massachnsetts.

By Grorge Ashton Black, Ph.D. Price, \$r.o.

VOLUME II, 1892-93. (See note on last page.)

1. The Economics of the Russian Village. By IsaAc A. Hourwich, Ph.D. (Out of print.)

2. Bankruptcy. A Study in Comparative Legislation.

BY SAMuel W. Dunscome, Jr., Ph.D. (Not sold separately.)

3. Speclal Assessments: A Study In MnnicipaliFinance.

By Victor Rosewater, Ph. D. Second Edition, 1898. Price, $\$ 1.00$.

VOLUME III, $1893.465 \mathrm{pp.}$ (Sold only in Sets.)

1. *Iistory of Elections in American Colonies.

By Cortind F. Bishor, Ph.D. Price \$2.00, cloth.

2. The Commercial Polley of England toward the American Colonles.

By Grorgr I. BEER, A.M. (Not sold separately.)

\section{VOIUME IV, 1893-94. $438 \mathrm{pp.} \mathrm{(Sold} \mathrm{only} \mathrm{in} \mathrm{Sets.)}$}

1. Financial History of Virginia.

By Williax Z. Ripley, Ph.D. Price, \$1.0a

2. The Inheritance Tax.

By Max Wrst, Ph.D. Second Edition, 1908. Price, \$2.00

3. History of Taxation in Vermont. By Frenerick A. Woov, Ph.D. (Not sold separately.)

VOLUMES V, 1895-96. 498 pp. Price, cloth, $\$ 3.50$.

1. Donble Taxation in the United States, By Francrs Walkgr, Ph.D. Price, \$1.00. 2. The Separation of Governmental Powerg, Wirliam Bondr, LL.B., Ph.D. Price, fr.co. 3. Municipal Government in Michigan and Ohio.

By Dizos F. Wilcox, Ph.D. Price, \$1.00

VOIUME VI, 1896. $601 \mathrm{pp}$. Price, cloth, $\$ 4.50$; Paper covers, $\$ 4.00$. History of Proprietary Government in Ponnsyivania.

By William Rogert Shgpherj, Ph.D.

VOLUMCE VII, 1896. 512 pp. Price, cloth, \$3.50.

1. History of the Transition from Provincial to Commonwealth Govern. ment in Massachusetts. By Harry A. Cushing, Ph.D. Price, \$2.00.

2. Speculation on the Stock and Produce Exchanges of tho United States.

By HenRy Crosey EMrex, Ph.D. Price, \$1.50.

VOLUME VIII, 1896-98. $551 \mathrm{pp.}$ Price, cloth, $\$ 4.00$.

1. The Struggle between President Johnson and Congress over Reconstruction. By Charles Erxiest Ciladsey, Ph.U. Price, 81.00

8. Recent Contralizing Tendencies in Stato Edncational Administration. By Willam Clarence Werster, Ph.D. Price, 75 cents.

3. The Abolition of Privateering and the Declaration of Paris.

By Francis R. Stark, LI. B., Ph.D. Price, \$1.00.

4. Pnblio Administration in Massachusotts. The Relation of Central to Local Activity.

By Rorert FIarvey Whitten, Ph.D. Price, p1.00. VOLUKI IX, 1897-98. 617 Fp. Price, cloth, $\$ 4.00$.

1. English Local Government of To-day. A Study of the Relations of Cen. tral and Local Government. By Milo Roy Maltbie, Ph. U. Price, \$2.00

2. German Wage Theories. A IIstory of their Development.

3. The Centralization of Administration in Now York Statc. 
VOLOME X, 1898-99. 500 pp. Price, cloth, \$3.50.

1. Sympathetic Strikes and Sympathetic Lockonta.

2 * Rhode Island and the Formation of the Union.

By Frizo S. HaIz, Ph.D. Fritz, oft.02.

By Frani Grzzane Batzo, Ph.D. Price, \$1. zo.

8. Centrallzed Administration of Liqnor Laws in the American Co:nmon. weaiths.

By Clemert Moore Lacey Sites, Pa.D. Price, fr.oo.

VOIUIE XI, 1899. 495 pp. Price, cloth, \$4.00; paper covers, $\$ 3.50$.

The Growth of Cities.

By Adsa Frrpix Wreser, Pa. D.

VOLUME XII, 1899-1900. 586 pp. Price, cloth, \$4.00.

1. History and Functions of Central Labor Unions.

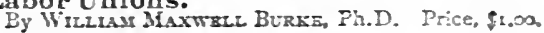

2. Colonial Immigration Laws.

By Edward Esmersox Proper, A.M. Price, 75 cents

3. History of Miltary Pensiou Legislation in tie United States.

By Willias Hevry Gisssos, Ph.D. Price, \$1.00.

4. History of the Theors of Soverelgnty since Rousseau.

By Charles E. Merriajr, Jr., Ph.D. Price, \$z.jo.

VOLUME XIII, 1901. 570 pages. Price, cloth, \$4.00.

1. Tho Legal Property Relatlons of Married Partias.

2. Political Yativism in Yew Fork State. By Lotrs Dow Scrsco, Ph.D. Price, $\$ 2.00$.

3. The Reconstruction of Georgia.

By Edwty C. Woozley, Ph.D. Price, \$t.020

VOLUME XIV, 1901-1902. 576 pages. Price, cloth, \$4.00.

1. Losalism in New York during the American Rerolntion.

By Alexander Ciarence Flick, Ph.D. Price, \$2.00. 2. The Economio Theory of Risk and Insnrance.

By Alzax H. Winlest, Ph.D. Price, \$r.50

3. The Eastern Question: A Study in Diplomac5.

By Stephen P. H. Duggax, Ph.D. Price, \$1.oo.

VOLUME XV, 1902. 427 pp. Price, cloth, $\$ 3.50$; paper covers, $\$ 3.00$.

Crime in Its Relations to Social Progress.

By Arthur Cleveland Hazl, PL.D.

VOLUME XVI, 1902-1903. 547 pp. Price, cloth, \$4.00.

1. The Past and Present of Commerce in Japan.

By Ýtaro Kixosita, Ph.D. Price, 8t.50

2. The Employment of Women in the Clothing Trade.

By Mabel Hurd Willet, Ph.D Price, \$r.jo.

3. The Centralization of Administration in Ohio.

By Siuruel P. Orth, Ph.D. Price, \$r.jo.

VOLUME XVII, 1903. $635 \mathrm{pp}$. Price, cloth, $\$ 4.00$.

1. Centrallzing Tendencies in the Administration of Indiana.

By Willias A. Rawles, Ph.D. Price, \$2.50

2. Principles of Jastice in Taxation.

By Stzphen F. Westos, Ph.D. Price, \$2,00.

VOLUME XVIII, 1903. $753 \mathrm{pp}$. Price, cloth, $\$ 4.50$.

1. Tue Administration of Iorra.

2. Turgot and the Six Edicts.

By Harolo Martix Bowmax, Ph.D. Price, \$r.jo. By Rorert P. Shepherd, Ph.D. Price, $\$$ t.jo.

3. Hanover and Prassia 1795-1so3.

By Gur Stastox Ford, Ph.D. Price, $\$ 2.00$,

VOLUME XIX, 1903-1905. 588 pp. Price, cloth, \$4.00.

1. Joslah Tucker, Economist.

By Walter Ervest Clark, Ph.D. Price, \$1.50.

2. IIstory and Criticism of the Labor Theorr of Talue in English Politlcal liconomy.

3. Trade Cnions and the Law in New York. By Algert C. Whrtaker, Ph.D. Price, \$r.50.

By Grorgs Gorhas: Grost, Ph.D. Price, \$r.oo.

VOLUMTE XX, 1904 $514 \mathrm{pp}$. Price, cloth, \$3.50.

2. The Office of the Justice of the Peace in England.

By Charles Austix Beard, Ph.D. Price, si.jo.

2. A Mistory of Military Governmont in Newly Acquired Territory of tho Lnited States. By David Y. Thoxas, Ph. D. Price, \$2.00. - VOLUME XXI, 1904. 746 pp. Price, cloth, \$4.50.

1. * Treaties, their Making and Enforcement.

2. The Sociology of a New York Cit. Bloct.

Ey Sarrzz B. Caavdalo, Ph.D. Price, \$1.50.

B. Pre-Malthuslan Doctriues of Populat:on.

Ey T:rostas Jass3 Joves, Ph.D. Price, \$\$.00.

By Limarzej E. Stangrland, Ph.D. Price, 37.50. 
VOLUME XXII, 1905.520 pp. Price, cloth, $\$ 3.50$; paper covers, $\$ 3.00$. The II istorical Development of the Poor Law of Connecticnt.

By EDWARd W. CAPEn, Ph.D.

VOLUME XXIII, 1905. 594 pp. Price, cloth, $\$ 4.00$.

1. The Economics of Land Tenure in Georgia.

1. Ty Enoch Marvin Banks, Ph.D. Price, \$r.oo,

2. Mistake in Contract. A Study in Comparative Jurisprudence.

By Epwin C. McKeag, Ph.D Price, \$1.00,

3. Combination in the Mining Industry. By Hexry R. Musser, Ph.D. Price, \$1.00.

4. The English Craft Guilds and the Government.

By Stella Kraker, Ph.D. Price, fr.oo.

VOIJME XXIV, 1905. $521 \mathrm{pp}$. Price, cloth, $\$ 4.00$.

1. The Place of Magfe in the Intell ectual History of Europe.

By LYNN THOKNDIKE, Ph.D. Price, $\$$ r.o.

2. The Ecclesiastical Edicts of the Theodosian Code.

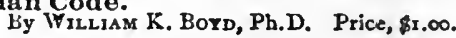

3. * The International Position of Japan as a Great Power.

By SEIjI G. Hishida, Ph.D. Price, \$2,00.

VOLUME XXV, 1906-0\%. 600 pp. (Sold only in Sets.)

1. * Munfeipal Control of Pablic Utilities. By O. L. Pond, Ph.D. (Not sold separately.)

2. The Budget in the American Commonwealths.

3. The Finances of Cleveland.

By Evgene E. Aggra, Ph.D. Price, \$r.so. VOLUME XXVI, 190\%. 559 pp. Price, cloth, $\$ 4.00$.

1. Trade and Currency in Early Oregon. By Jamss H. Gilgert, Ph.D. Price, $\$ 1 . \infty$.

a. Luther's Table Talk.

3. The Tobacco Industry in the United States.

By Mexer Jaconstein, Ph.D. Price, \$1.50.

4. Social Democracy and Population. By Alvan A.Tennet, Ph.D. Price, 75 cents.

VOLUME XXVII, 1907. 578 pp. Price, cloth, \$4.00.

1. The Economic Polley of Robert Waipole. By Norris A. Brisco, Ph.D. Price, fr.50.

2. The United States Steel Corporation. By Abraham Berglund, Ph.D. Price, 8i.50.

3. The Taxation of Corporations in Massachusetts.

By Hakry G. Frurdman, Ph.D. Price, \$1.50.

VOLUME XXVIII, 1907. 564 pp. Price, cloth, \$4.00.

1. Delvitt Clinton and the Origin of the Spolls System in New York.

By Howard LeE MCBAIN, Ph, D. Price, \$1.50.

2. The Development of the Legislature of Colonial Virginia.

By ELMER I. MILLLR, Ph.D. Price. \$r.50.

3. The Distribution of Ownership. By Joseph Harding Underwood, Ph.D. Price, \$r.50.

VOLUME XXIX, 1808, 703 pp. Price, cloth, $\$ 4.50$.

1. Early New England Towns.

2. New Hampshire as a Royal Province.

By Anne Bush Maclear, Ph.D. Price, \$r.5o. By William H. FRY, Ph.D. Price, $\$ 3.00$.

VOLUME XXX, 1908. $712 \mathrm{pp}$. Price, cloth, \$4.50; paper covers, \$4.00.

The Province of New Jersey, 1664-1738. By Edwin P. Tanner, Ph.D.

VOLUME XXXI, 1908. $575 \mathrm{pp}$. Price, cloth, $\$ 4.00$.

1. Private Freight Cars and American Railroads.

By RogrR E. CHadnock,
3. Cousanguineous Marriages in th 9 American Popnlation.

By L. D. H. Weln, Ph.D. Price, \$r.50.

By Rosert E. Chadnock, Ph.D. Price, \$1.50

4. Adolphe Quetelet as 8 tatistician.

By Grokge B. Lours AkNer, Ph.D. Price, 75 cents. By Fank H. Hankins, Ph.D. Price, \$r.25.

VOLUME XXXII, 1908. 705 pp. Price, cloth, \$4.50; paper covers, $\$ 4.00$. The Enforcement of the Statutes of Laborers. By Eertha Haven Putnan, Ph.D.

VOLUME XXXIII, 1908-1909. 635 pp. Price, cloth, $\$ 4.50$.

1. Factory Legisiation in Maine.

By E. StagG Whitin, A.B. Price, \$r.oo.

2. "Isychological Interpretations of Society,

By Micharl M. Davis, JR., Ph. D. Price, \$2,00.

3. * An Introdnction to the Sources relating to the Germanic Invasions.

by Carlto Hunteley HAYes, Ph.D. Price, sir.sa 
VOLDME XXXIV, 1909. 628 pp. Price, cloth, $\$ 4.50$.

1. [89] Transportation and Industrial Development in the Middie VVest.

7. [90] Social Reform and the Reformation. By Willau F. Cephart, Ph.D. Price, 82.00 .

s. [91] Responsiblity for Crime.

By Philip A. Parjons, Ph.D. Price, $\$ 5.50$

VOIUME XXXV, 1909. 568 pp. Price, cloth, $\$ 4.50$.

1. [92] The Conilict over the Judiclal Powers in the United States to 1870.

8. [83] A study of the Popalation of Manhattanville. Hises, Ph.D. Price, \$3.50.

8. [94]* Divorce: A study in Soclal Causation.

By Jakres P. Lichtrembrgzr, Ph.D. Price, $\$ 1.50$.

VOLUME XXXVI, 1910. 542 pp. Price, cloth, \$4.00.

1. [95] * Reconstruction In Texas. By Charles Willtam Rasisdezi, Ph.D. Price, \$2.50. 2. $\{96 \mid$ * The Transition in Virginia from Colony to Commonwealtb

By Charles Raysdeli Lisglex, Ph.D. Price, 21.50 .

VOLUME XXXVII, 1910. 606 pp. Price, cloth, $\$ 4.50$.

1. [97] Standards of Reasonableness in Local Freight Discriminations.

8. [98] Legal Derelopment in Colonfal By JoHs MAURICE Chark, Ph.D. Price, \$5.s5.

2. [88] Legal Development in Colonial Massachusetts

8. [99] * Social and Mental Traits of the By Charles J. Hilkex, Ph.D. Price,\$r.25. gy Charles J. Hilkeg, Ph.D. Price, \$r.25.
By Howard W. Odusz, Ph.D. Price, \$2.00.

VOLUME XXXVIII, 1910. 463 pp. Price, cloth, $\$ 3.50$.

1. [100] The Pnblle Domain and Democracy

8. [101] Organismic Theories of the State. By Francis W. Coker, Ph.D. Price, \$1.50.

VOLUME XXXIX, 1910-1911. 651 wp. Price, cloth, \$4.50.

1. [102] The Maklng of the Ba!kan States.

2. Ey ivilitasr Smith Murray, Ph.D. Price, \$1.jo.

2. [103] Political History of New York State during the Period of the Civil war.

By Sidnex David Brousmer, Ph, D. Price, 3.00 .

VOLUME XL, 1911. 633 pp. Price, cloth, \$4.50.

1. [104] A Surrey of Constitutional Development in China.

8. [105] Ohio Politics during the Civil War Period.

B. [106] The Territorial Rasis of Government under the State Constitutions.

BY ALRRED ZANTZINGER RERD, Ph.D. Price, \$r.75.

VOLUME XLI, 1911. 514 pp. Price, cloth, $\$ 3.50$; paper covers, $\$ 3.00$.

[107] New Jerseyas a Royal Province.

By Edgar Jacos Fisher, Ph. D.

VOLUME XIII, 1911. 400 pp. Price, cloth, $\$ 3.00$; paper covers, $\$ 2.50$.

[108] Attitude of American Courts in Labor Cases.

By Grorga Gorhas Gront, Ph.D.

VOLUME XIII, 1911. 633 pp. Price, cloth, \$4.50.

1. [109] *Industrial Causes of Congestion of Popalation in New York City.

2. [1 10] Education and the Mores. BY EDWARD EWING PRATT, Ph.D. Price, \$2.

8. [111] The British Consuls in the Confederacy.

By Millledge L. Bonhay, JR., Ph.D. Price, \$2.00.

VOLUMES XLIV and XLV, 1911. 745 pp.

Price for the two volumes, cloth, $\$ 6.00$; paper covers, $\$ 5.00$.

[112 and 113] The Economic Principles of Confucius and his Schoor.

VOLUMS XIVI, 1911-1912. 623 pp. Price, cloth, \$4.50.

1. [114] The Rlcardian Socialists.

Dy Esther Lowenthaz. Ph.D. Price. \$r.o

2. [115] Ibrahim Pasha, Grand Tizlel of Suleiman, the Magnificent.

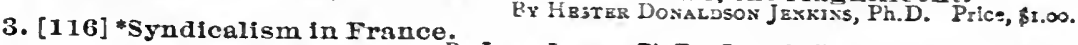

4. [117] A Hoosfer Fillage.

Br Lours Lrvixz, Ph.D. Second edition, s9r4. Price, $\$ 1.50$. BY New 
VOLUME XIVII, 1912. 544 pp. Price, $\mathrm{cloth}_{1} \$ 4.00$.

1. [118] The Politics of Michigan, 1865-1878, 2. $[119]$ *The United States Beet Sugar Industry and the Tariff. Price, $\$ 2 . \infty$

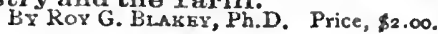

\section{VOLUMIE XIVIII, 1912. $493 \mathrm{pp.}$ Price, cloth, $\$ 4.00$.}

1. [120] Isidor of Seville.

3. [121] Progruss and Unformityin Child-rabor Legislation.

By Ernest Brehaut, Ph. D. Price, \$2..$\infty$. By Williak Figlding Ogrurn, Ph.D. Price, 1.25 .

VOLUMIE XIIX, 1912. 592 pp. Price, cloth, $\$ 4.50$.

1. [1:2] British Radicalism 1791-1797.

By Walter Phelps Hall. Price, \$2.00. 1: [1 3 3 A Comparative Study of the Law of Corporations.

3. [124] *The Negro at Work in New York City.

Jy Arthur K. Kunn, Ph.D. Price, \$1.50. By Grorge E. Haynes, Ph.D. Price,\$r.25.

VOLUME I, 1911. 481 pp. Price, cloth, \$4.00.

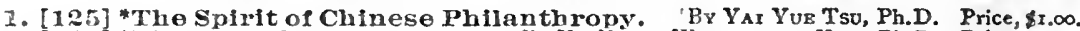
2. [1:6] *'ihe Alfen in China. By VI. KYuiN WeLlingtos Koo, Ph.D. Price, \$2.50.

VOLUME II, 1912. 4to. Atlas. Price: cloth, \$1.50; paper covers, \$1.00. 1. [127] The Sale of Liquor in the South.

By Leonard S. Blakey, Ph.D.

VOLUME III, 1912. 489 pp. Price, cloth, $\$ 4.00$.

1. [128] *Provincial and Local Taxation in Canada.

2. [129]*The Distribution of Income.

8. [130] *The Finances of Vermont.

BY Solobion Vineare, Ph.D. Price, 81.50. By Frank Hatch Streightopf, Ph.D. Price, \$1.50. By Freder:ck A. Wood, Ph.D. Price, \$1.00.

VOLUME IIII, 1913. 789 pp. Price, clotin, \$4.50; paper, $\$ 4.00$.

[131] The Civil Warand Reconstruction in Florida. :By W. W. Dayis, Ph.D.

VOLUME IIV, 1913. $604 \mathrm{pp}$. Price, cloth, \$4.50.

1. [132] *Privileges and Immunities of Citizens of the Jnitod Etates.

By ARNOLn JOHNSON LIEN, Ph.D. Price, 75 cents.

פ. [133] The Supreme Conrt and Unconstitutional Legisiation.

By BLAINE FREE MlOORE, Ph.D. Price, \$1.00.

8. [134] "Indian Slavery in Colonial Times within the Present Iimits of the United Staces.

by Almon Whegler Laubir, Ph. D. Price, $\$ 3.00$.

VOTUME LV, 1913. 665 pp. Price, cloth, $\$ 4.50$.

1. [135] *A Political IIistory of the State of Now York.

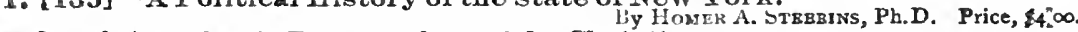
8. [136] "The Early Persecutions of the Christians.

By Leon H. Canfield, Ph.D. Price, \$1.50.

VOLUME LVI, 1913. 406 pp. Price, cloth, $\$ 3.50$.

1. [137] Speculation on the New York Stock Exchance. $1004-1907$.

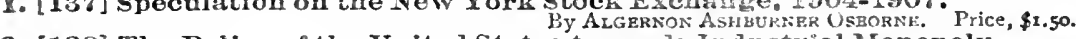
2. [128] The Policy of the United States towards Industrial Monopoly.

By Oswald Whituais Kaul', Ph.D. Price, $\$ 2.00$

VOLUME LVII, 1914. $670 \mathrm{pp.} \mathrm{Frice,} \mathrm{cloth,} \mathrm{\$ 4.50.}$

1. [138] *The Civil Service of Great Britain.

2. [140] The Financial Mistory of New Fork State.

By Rogert Moses, Ph.D. Price, $\$ 2.00$. By Don C. Sowers. Price, \$2.50.

VOIUMA IVIII, 1914. $684 \mathrm{pp}$. Price, cloth, \$s.50; paper, \$4.00.

[141] Reconstruction in Nor'th Carolina.

By J. G. De Rovinac Hamilton, Ph.D.

VOLUME IIX, 1914. 625 pp. Frice, cloth, $\$ 4.50$.

1. [14:] The Development of Modern Turkey by means of its Press.

1. [14.2] The Development or Modern Turkey by means of

2. [143] The System of Taxation in China, 1614-1911.

3. $[144]$ The Currency Problem in China. BY WEN PIN Wri, Ph.D. Price, \&I.25.

4. 145 *Jewish Immigration to the United states.

by SAMuzd Joseph, Ph.D. Price, \$1.50. 
VOLUME LX, 1914. 516 pp. Price, cloth, $\$ 4.00$.

1. $[146]$ * Constantine the Great and Christlanity.

By Christophex Bush Coleman, Ph. D. Price, \$2.00.

2. [147] The Estabilshment of Christianity and the Proscription of Pagaulsm. By Maud aline Hutrmans, Ph.D. Price, \$\$, $\$$.

\section{VOLUME LXI, 1914. 496 pp. Price, cloth, $\$ 4.00$.}

1. [148] *The Rallway Conductors: A Study in Organlzed Labor. By Euwin Clyde RueEins. Price, $\mathbf{z r} .50$. 2. [149] *The Finances of the Clty of New York.

By Yis-Ch'U MA, Ph.D. Price, \$2.50.

VOLUME LXII, 1914. $414 \mathrm{pp.} \mathrm{Price,} \mathrm{cloth,} \mathrm{\$ 3.50.}$

[150] The Journal of the Jolnt Committee of Fifteen on Reconstruction, 39 th Congress, $1865-1867$. By binjasin B. Kendrick, Ph. 1, Price, \$3.00.

\section{VOLUME IXIII, 1915. 561 pp. Price, cloth, $\$ 4.00$.}

1. $\{151\}$ Emile Durkhelm's Contributions to Soclological Theory.

2. [152] The Nationallzation of Rallways in Japan.

By Charles Elazk GehlKB, Ph.D. Price, \$r.50.

3. [153] Population: A Study In Malthuslanism.

By Toshiharu Watarai, Ph.D. Price, \$1.25. By WARRgs S. Thonpson, Ph.D. Price 81.75.

VOLUME LXIV, 1915. 646 pp. Price, cloth, \$4.50.

1. [154] *Reconstruction In Georgla. By. C. Mildred Thompsos, Ph.D. Price, \$3,00.

2. [155]*The Review of American Colonial Legislation by the King in Council.

By Elarer BeEcher Russell, Ph.D. Price, \$1.7j.

VOLUME LXV, 1915. 496 pp. Price, cloth, $\$ 4.00$.

1. [156] *The Soverelgn Councll of New France.

1. [156] Raymond Du Bors Cahall, Ph.D. Price, \$2.25.

2. [157] *gelentifle Manggement. By Horacr Bookwaltar Drury, Ph.D. Price, \$1.75.

VOLUME LXVI, 1915. 655 pp. Price, cloth, $\$ 4.50$.

1. [158] The Recognition Policy of the United States.

2. [159] Railway Problems in China.

3. [160] *The Boxer Rebellion.

By Julius Gorarl, JR., Ph.D. Price, \$2.00 Bу Снин Hsu, Ph.D. Price, \$r.5o.

By Paul H. Clements, Ph.D. Price, \$2.00.

VOLUME LXVII, 1916. 538 pp. Price, cloth, $\$ 4.00$.

1. [161] *Rnsslan Sociology.

By Julius F. Hecker, Ph.D. Price, \$2.50.

2. [16:] State Regulation of Rallroads in the South.

By Maxwell Errguson, A M , LL.B.; Price, \$r.75.

VOLOME LXVIII, 1916. 518 pp. Price, cloth, $\$ 4.50$.

[163] The Origins of the Islamic State. By Philip K. Hitri, Ph.D. Price, 84,00.

VOLUME LXIX, 1916. 489 pp. Price, cloth, \$4.00.

1. [164] Rallway Monopoly and Rate Regulation.

2. [165] The Butter Industry in the United Stgtes.
By Eoward Wirst, Ph.D. Price, $\$ 2 . \infty$. 
VOLUME LXX, 1916. 536 pp. Price, cloth; $\$ 4.50$.

[166] Mohammedan Theories of Finance.

By Nicolas P. Aghnides, Ph.D. Price, \$4.00.

\section{VOLUME LXXI. 1916.}

1. [167] The Comnerce of Loulsfana during the French Régtme, 1699-1763. By N. M. MILLER SURREY. (In press).

VOLUME IXXII. 1916. 542 pp. Price, cloth, $\$ 4.50$.

1. [168] Amerlcan Men of Letters: Their Nature and Nurture.

2. [169] The Tariff Problem in China.

3. [170] The Marketing of Perishabie Food Products.

By Edwin Leavitr Clarkr, Ph.D. Price, \$r.50. By Chin Chu, Ph. D. Price, \$r.50.

By A. B. Adams, A.M. Price, \$r.5o.

VOLUME LXXIII. 1916.

1. [171] The Social and Economfc Aspects of the Chartist Movement

2. [172] The Decline of the Chartist Movement.

By Frank F. Rosenblatt. (In press).

3. [173] Chartism and the Churches.

By Preston William Siosson. (In press).

VOLUME LXXIV. 1916.

1. [174] The Rise of Ecclesiastical Control in Quebcc.

By Waltir A. Riddrll, (In press).

The price for each separate monograph is for paper-covered copies; separate monographs marked*, can bo supplled bound in cioth, for 50c. additlonal. All prices are not.

The set of seventy volumes, covering monographs 1-166, is offered, bound, for \$234: except that Volume II can be supplied only in part, and in paper covers, no. I of that volume being out of print. Volumes III, IV and XXV, can now be supplied only in connection with complete sets.

For further information, apply to

Prof. EDWIN R. A. SELIGMAN, Columbia University, or to Messr8. LONGMANS, GREEN \& CO., New York. London: P. S. KING \& SON, Ltd., Orchard House, Westminster. 


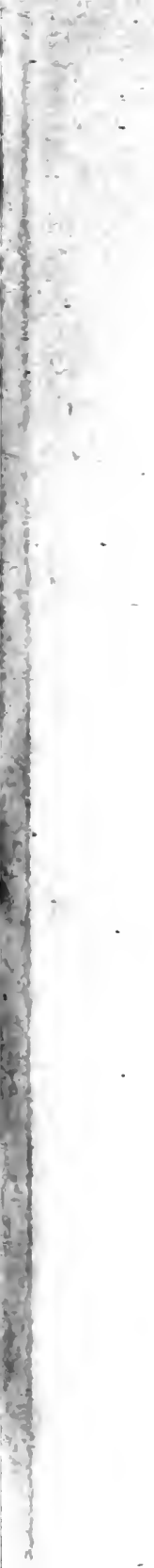





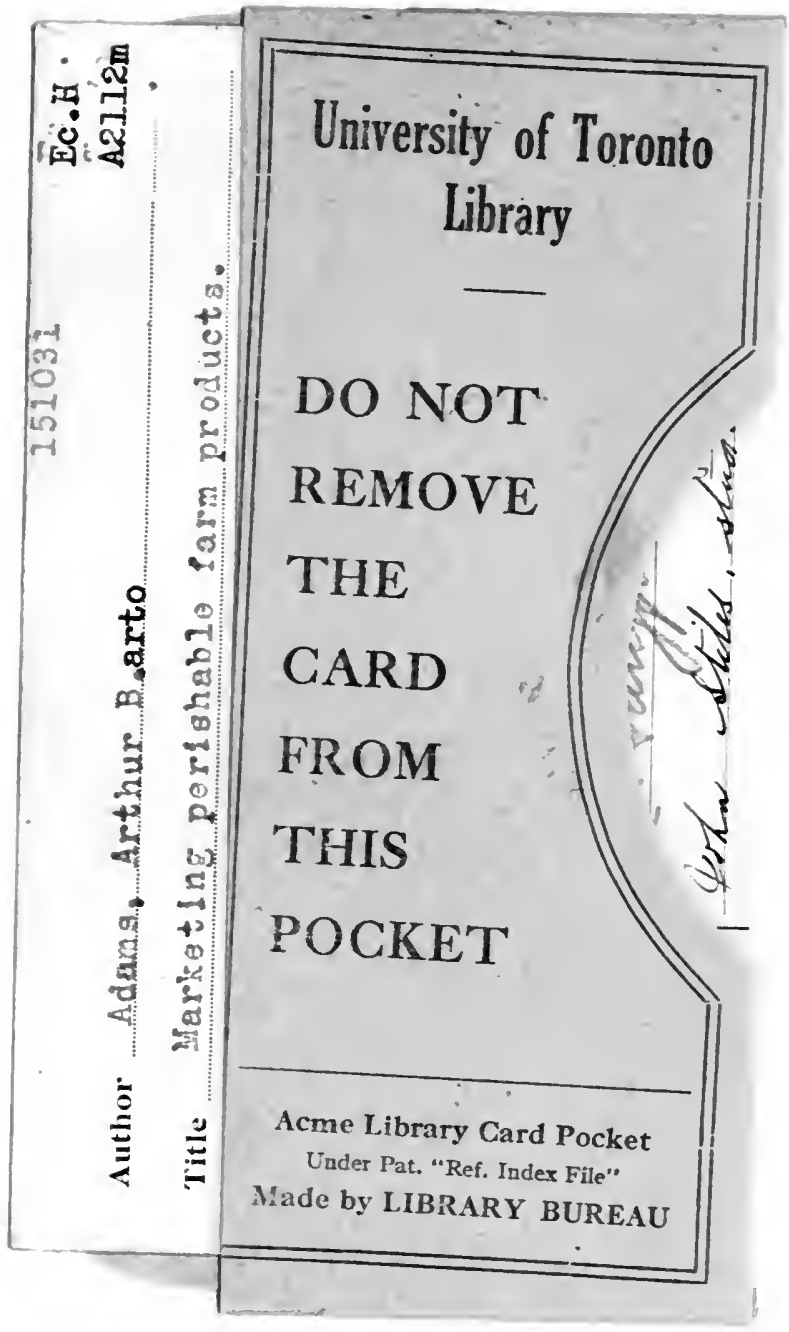




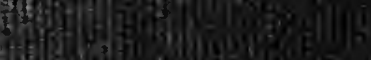
fif H(1) 8)

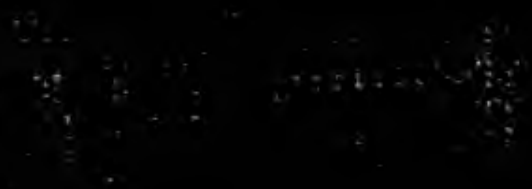

